Maurice A. Deane School of Law at Hofstra University Scholarly Commons at Hofstra Law

Hofstra Law Faculty Scholarship

$12-2002$

\title{
Rational Actors, Self-Defense, and Duress: Making Sense, Not Syndromes, Out of the Battered Woman
}

Alafair S. Burke

Hofstra

Follow this and additional works at: https://scholarlycommons.law.hofstra.edu/faculty_scholarship

\section{Recommended Citation}

Alafair S. Burke, Rational Actors, Self-Defense, and Duress: Making Sense, Not Syndromes, Out of the Battered Woman, 81 N.C. L. Rev. 211 (2002)

Available at: https://scholarlycommons.law.hofstra.edu/faculty_scholarship/165

This Article is brought to you for free and open access by Scholarly Commons at Hofstra Law. It has been accepted for inclusion in Hofstra Law Faculty Scholarship by an authorized administrator of Scholarly Commons at Hofstra Law. For more information, please contact lawcls@hofstra.edu. 


\title{
RATIONAL ACTORS, SELF-DEFENSE, AND DURESS: MAKING SENSE, NOT SYNDROMES, OUT OF THE BATTERED WOMAN
}

\begin{abstract}
ALAFAIR S. BURKE*
In this Article, Professor Burke recommends an alternative approach to understanding the conduct of battered women. Current advocacy on behalf of battered women accused of criminal offenses focuses on the now familiar battered woman syndrome theory. Although the battered woman syndrome theory has enjoyed broad support when asserted by defendants claiming self-defense, Professor Burke questions the earnestness of the theory's judicial acceptance. First, in light of both empirical and analytical flaws in the battered woman syndrome theory, the overwhelming judicial acceptance of the theory is inconsistent with the courts' growing tendency to scrutinize scientific evidence. Second, courts have been reluctant to extend the battered woman syndrome to the defense of duress, where the theory would excuse battered women who commit crimes with their batterers against innocent parties. That the syndrome theory has been controversial in duress cases, and yet widely accepted in the self-defense context, despite its analytical and scientific flaws, suggests that the battered woman syndrome has been used in the self-defense context to help sympathetic actors.
\end{abstract}

Professor Burke suggests that the self-defense claims of justified battered women have failed under traditional self-defense rules not because battered women are qualitatively different than other actors, but because current self-defense rules are imperfect generally and do not encompass all necessary uses of defensive force. She proposes an alternative approach to these cases that would treat battered women as rational actors and ask whether their use of defensive force was necessary. Professor Burke argues that, unlike the prevailing approach to the battered woman cases,

* Associate Professor, Hofstra University School of Law. B.A., Reed College; J.D., Stanford Law School. I would like to thank Guyora Binder, Robin Charlow, Cynthia Lee, Peter Spiro, and Robert Weisberg for their helpful comments on previous drafts. I am grateful to Connie Lenz, Associate Director for Collection Development of the University of Minnesota La:v Library and former Assistant Director of the Hofstra Law Library, and to Lisa Pessah for their dedicated research assistance. 
the recommended rational actor approach preserves the importance of objective standards when justifying defensive force. Moreover, an emphasis upon objective standards when applying criminal defenses reconciles the existing tension between the treatment of battered women in the duress and self-defense contexts. Viewed as rational actors and not psychologically impaired, battered women who defend themselves against their batterers have stronger normative claims that their conduct was necessary than battered women who appease their batterers by victimizing third parties.

INTRODUCTION

I. OVERVIEW OF THE BATTERED WOMAN SYNDROME AND

ITS APPLICATION TO CLAIMS OF SELF-DEFENSE......................220

A. The Prevailing View of the Battered Woman ......................221

B. Battered Woman Syndrome and Self-Defense ....................225

1. Traditional Elements of Self-Defense

2. The Resort to the Battered Woman Syndrome

Theory ....

II. FLAWS IN THE BATTERED WOMAN SYNDROME THEORY ....232

A. Flawed Research on Battered Woman Syndrome ...............232

B. Poor Fit Between the Battered Woman Syndrome

Theory and Self-Defense

C. Refusal to Apply to Duress Claims Demonstrates

Result-Oriented Acceptance of Theory....

1. Traditional Law of Duress

2. Extension of Battered Woman Syndrome to Duress Claims

III. AN ALTERNATIVE EXPLANATION FOR WHY BATTERED WOMEN STAY AND THE IMPLICATIONS UPON CRIMINAL DEFENSES 266

A. An Alternative Understanding of Battered Women ............267

B. Battered Women Who Kill and Self-Defense........................273

1. Necessary Force is Justified Force .................................274

2. An "Objective" Contextualization of the Reasonableness Standard ............................................286

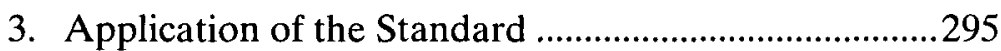

C. Advantages of Viewing Battered Women as Rational Actors

D. Battered Women as Rational Actors and the Defense of Duress. 


\section{INTRODUCTION}

When should a homicide go unpunished? For purposes of comparison, consider three cases of claimed self-defense.

A young man initiates a confrontation with Anthony by continually pestering Anthony for a marijuana cigarette outside of a liquor store. ${ }^{1}$ The would-be pot buyer's friend joins the conflict, raising his fists and challenging Anthony to a fight. Anthony is armed with a knife, so he could walk away from the challenge without serious harm if he tried. On the other hand, he has a reasonable belief that, if he stays, deadly force is necessary to protect himself.

Edith has been physically and emotionally abused by her husband, Kenneth, for eighteen years, but she still loves him. ${ }^{2}$ A week after Kenneth last beat Edith, he moves out of the family home and files for divorce. When Edith visits Kenneth to talk about the divorce, she brings a gun and rubber gloves with her, and Kenneth leaves the safety chain on his door. After a fight through the cracked door about the divorce and money, Edith shoots Kenneth dead and stashes her gun and gloves.

1. Anthony is based on the defendant in Idrogo v. People, 818 P.2d 752 (Colo. 1991). In Idrogo, the defendant was convicted of reckless manslaughter after he stabbed a stranger after a confrontation outside of a liquor store. Id. at 752-53. The decedent's brother continually pestered Idrogo to sell him marijuana, and Idrogo eventually pulled a knife when his requests to be left alone were ignored. Id. at 753 . The decedent intervened and continued to approach Idrogo, even after Idrogo said he was leaving and did not want any trouble. Id. After a fight ensued, Idrogo stabbed the man, killing him. Id. The Colorado Supreme Court reversed Idrogo's conviction based upon the trial court's failure to instruct the jury that an innocent person is not required to retreat before using deadly force when the use of such force is reasonable under the circumstances. Id. at 754-57. In the actual case, Idrogo had a good argument that his use of force was necessary and that there was no other alternative. Before the fight ensued, he continually attempted to back away from the confrontation, communicating his intentions to leave without any trouble. Id. at 753. For purposes of this hypothetical, Anthony does not attempt to retreat from the confrontation that triggers defensive force.

2. Edith is based on the defendant in Buhrle v. State, 627 P.2d 1374 (Wyo. 1981). In the actual case, the decedent had moved out of the house and was in the process of seeking a divorce and applying for a restraining order when the defendant killed him. Id. at 1375. The defendant testified that her husband had asked her to go to his motel to talk. Id. at 1376 . She took a hunting rifle and rubber gloves with her, and her husband kept the night chain of his motel door secured while they spoke. Id. During a nearly two hour long conversation, witnesses heard the two argue about money and the divorce. Id. The defendant shot her husband through the motel door, and then hid her gun and gloves and claimed that someone else had shot him. Id. Lenore Walker, a leading expert on the battered woman syndrome, offered to testify in support of defendant's self-defense claim. Id. at 1376-77. See infra note 113 for further discussion of Walker's proffered testimony. The Wyoming Supreme Court affirmed the defendant's murder conviction, concluding that the exclusion of Walker's testimony was proper, because the defense had failed to lay an adequate foundation for the expert opinion. Buhrle, 627 P.2d at 1377-78. 
Judy has been physically and emotionally abused by her husband for two decades. ${ }^{3}$ Judy has tried leaving her husband several times, but each time, he finds her, brings her home, and beats her. After a recent beating, police leave without arresting her husband because Judy tells them she is too afraid to sign a complaint against him. When her husband discovers the next day that she is applying for welfare benefits to support herself and is looking into having him committed, he brings her home, beats her, extinguishes a cigarette against her skin, and threatens to kill her. When her husband finally falls asleep, Judy shoots him in the head.

Whom, if anyone, should the criminal law punish? To place the question within the posture of a criminal case, who among Anthony, Edith, and Judy, if anyone, should be permitted to present a selfdefense claim to the jury that weighs their fate? American criminal law's traditional approach to self-defense would permit Anthony, but not Edith or Judy, to claim self-defense and have an instruction delivered to the jury explaining the scope of the right to use defensive force. Only Anthony could show that he had a reasonable fear of an imminent threat to his physical safety, the bellwether self-defense standard. ${ }^{4}$ Because neither Edith nor Judy faced an imminent threat, traditional notions of self-defense would treat these actors the same, each equally without a right to use defensive force.

Advocates for battered women have argued that Edith and Judy should also have the opportunity to present a self-defense claim. ${ }^{5}$

3. Judy is based on the defendant in State v. Norman, 324 N.C. 253 , 378 S.E. 2 d 8 (1989). Norman killed her husband after surviving twenty-five years of physical and emotional abuse that involved burning cigarettes against her body, breaking glass against her face, and forcing her to eat dog food from a pet bowl and sleep on the floor. Id. at 254-55, 378 S.E.2d at 9-10. Her husband forced her into prostitution, and then would humiliate her in front of others for being a prostitute. Id. at 255, 378 S.E.2d at 10 . The case is discussed further in Section I.B., infra notes 76-81 and accompanying text.

4. See generally JOSHUA DRESSLER, UNDERSTANDING CRIMINAL LAW 221-23 (3d ed. 2001) (discussing the general principles of self-defense); WAYNE R. LAFAVE, CRIMINAL LAW 491 (3d ed. 2000) (same).

5. Norman has been the focus of considerable scholarly discussion. See, e.g., Claire O. Finkelstein, Self-Defense as a Rational Excuse, 57 U. PITT. L. REV. 621, 623-31 (1996) (arguing for a rational excuse self-defense standard); Martha R. Mahoney, Legal Images of Battered Women: Redefining the Issue of Separation, 90 MiCH. L. REv. 1, 89-92 (1991) (applying the concept of separation assault to Norman); Richard A. Rosen, On SelfDefense, Imminence, and Women Who Kill Their Batterers, 71 N.C. L. REV. 371, 398 (1993) (arguing that Norman should be entitled to a self-defense claim); Benjamin C. Zipursky, Self-Defense, Domination, and the Social Contract, 57 U. PITT. L. REv. 579, 583-85 (1996) (discussing the lack of genuine alternatives as a basis for a self-defense claim); Kerry A. Shad, Note, State v. Norman: Self-Defense Unavailable to Battered Women Who Kill Passive Abusers, 68 N.C. L. REv. 1159, 1159-77 (1990) (concluding that voluntary manslaughter should be expanded to include battered woman syndrome cases 
Usually, the argument in favor of self-defense claims for women like Edith and Judy is made by relying on the battered woman syndrome theory, which describes the victims of repeated domestic violence as incapable of recognizing alternatives to an abusive environment and susceptible to perceiving a threat of an imminent attack, even when there is none. ${ }^{6}$ Some have advocated changes in the formal legal standards defining the right to use defensive force, such as a relaxation of the imminency requirement, ${ }^{7}$ or a right to use force to protect oneself from severe psychological abuse. ${ }^{8}$ The tendency among these advocates, however, is not to distinguish among battered women who kill their abusers, but to argue the reasons why battered women generally should be granted a broader right to engage in defensive force. At least implicitly, then, these reformist notions of self-defense-like traditional notions of self-defense-treat Edith and Judy as identical actors, albeit with more chance of claiming selfdefense than under traditional legal standards. ${ }^{9}$

like Norman).

6. See generally Lenore E. Walker et al., Beyond the Juror's Ken: Battered Women, 7 VT. L. REV. 1, 1 (1982) (discussing efforts to understand the psychology of battered woman syndrome). The argument is exemplified by the Kansas Supreme Court's opinion in State v. Hodges, where the court reversed a battered woman's murder conviction based on the trial court's exclusion of expert testimony regarding battered woman syndrome. 716 P.2d 563, 570 (Kan. 1986), overruled on other grounds by State v. Stewart, 763 P.2d 572 (Kan. 1988). In doing so, the court reasoned,

Evidence of the battered woman syndrome is not a defense to a murder charge.

The evidence is introduced to help the jury understand why a battered woman is psychologically unable to leave the battering relationship and why she lives in a high anxiety of fear from the batterer. The evidence aids the jury in determining whether her fear and her claim of self-defense are reasonable.

Id. Section I of this Article provides an extensive overview of the argument that the battered woman syndrome theory is relevant and helpful to a self-defense claim.

7. Rosen, supra note 5, at 404-07; Jeffrey B. Murdoch, Comment, Is Imminence Really Necessity? Reconciling Traditional Self-Defense Doctrine with the Battered Woman Syndrome, 20 N. ILL. U. L. REV. 191, 217-18 (2000).

8. Charles Patrick Ewing, Psychological Self-Defense: A Proposed Justification for Battered Women Who Kill, 14 LAW \& HUM. BEHAV. 579, 581-90 (1990).

9. As one commentator has noted, "observers too often concentrate on a small set of notorious cases where the system has clearly failed, such as that of Judy Norman." Robert P. Mosteller, Syndromes and Politics in Criminal Trials and Evidence Law, 46 DUKE L.J. 461, 487 n.87 (1996); see also Joshua Dressler, Battered Women Who Kill Their Sleeping Tormentors: Reflections on Maintaining Respect for Human Life while Killing Moral Monsters, in CRIMINAl LAW THEORY: DOCTRINES OF THE GENERAL PART 259, 264 (Stephen Shute \& A.P. Simester eds., 2002) (discussing Norman "not because it represents an average battering relationship, but because it perhaps does not") (emphasis in original). Typically, advocates for the battered woman syndrome theory or for reform of formal selfdefense standards to accommodate the self-defense claims of more battered women rely upon the facts of a case like Norman to support their arguments, suggesting that Judy Norman represents the typical battered woman who kills. E.g., Mahoney, supra note 5, at 
But why should Edith's and Judy's self-defense claims rise or fall together? Surely not because they are both women who killed abusive husbands. In no other context does the law apply statusspecific rules to defensive force. For example, when a robbery victim kills his robber, his right to do so (or at least his right to claim such a right before a jury) cannot be determined just from the property owner-robber relationship between killer and deceased. Courts look at the facts case-by-case to determine whether a prima facie selfdefense claim has been made. ${ }^{10}$

Looking at Edith, Judy, and Anthony as separate actors, who has the best claim to self-defense? This Article's purpose is to explain why the law should recognize Judy as the most justified defensive actor, even though traditional self-defense jurisprudence bars Judy from asserting a self-defense claim. ${ }^{11}$ Advocates for battered women who kill have attempted to avoid the self-defense rules that bar Judy's claim by relying upon the so-called battered woman syndrome. As explored further in this Article, however, the theory has little empirical support, treats battered women as homogenous so that their self-defense claims rise and fall together, depicts battered women as cognitively impaired and irrational, and ultimately fails to explain. why a battered woman might kill her sleeping husband. ${ }^{12}$ Moreover, it does nothing to jettison the faulty doctrinal rules that formed the impetus for the syndrome theory as a litigation strategy. An alternative approach is to change the rules themselves to reflect better the notion that force should be justified when and only when it is necessary. This Article recommends treating (and judging) battered women who kill as rational actors, but changing doctrinal

89 (citing Norman as exemplifying the need for a better judicial understanding of the "separation assault" phenomenon); Rosen, supra note 5, at 372, 402 (recognizing that most battered women who kill do so in response to an imminent threat, but citing Judy Norman as the impetus for advocating an expanded self-defense standard). My reliance on Norman is from a different perspective, as I would distinguish among battered women and permit expanded rights to defensive force for some, but not all, of them.

10. Compare Harper v. United States, 608 A.2d 152, 153-56 (D.C. 1992) (per curiam) (affirming trial court's denial of a self-defense instruction where defendant pursued alleged robber out of the store and up the street before shooting him, allegedly in selfdefense), with Hayes v. Commonwealth, 870 S.W.2d 786, 787-89 (Ky. 1993) (finding error in the failure to give a self-defense instruction where robbery victim/defendant testified that he shot decedent only after being fired at first by a man who had robbed him).

11. See State v. Norman, 324 N.C. 253, 266, 378 S.E.2d 8, 16 (1989) (affirming the conviction of Judy Norman and holding that the trial court's refusal to instruct the jury regarding self-defense was not error).

12. See infra Section II.B. 
self-defense rules so that they more accurately justify all necessary uses of force. ${ }^{13}$

Previous critics of the psychological components of the battered woman syndrome theory, notably Elizabeth Schneider, Martha Mahoney, and Holly Maguigan, have argued that battered women's ability to present to the jury an accurate and complete depiction of the reality of their lives is the key to successful self-defense claims, not a change in formal legal standards. In non-confrontation cases, however, the imminency requirement will hinder self-defense claims, even when the defendant could not leave her batterer without risking her own death. ${ }^{14}$ Richard Rosen's suggestion of jettisoning the imminency requirement and recognizing necessity as the prevailing self-defense standard ${ }^{15}$ would permit necessary uses of nonconfrontational defensive force. Rosen's vision, however, would use necessity as the standard for defensive force only in exceptional cases and would perpetuate the use of the battered woman syndrome theory to support litigants' reliance upon psychologicallyindividualized standards of "reasonableness." 16

13. See infra Section III.B.

14. Schneider emphasizes the need to ensure battered women "equal rights to trial," rather than the creation of any special defense for battered women. See, e.g., ELIZABETH M. SCHNEIDER, BATTERED WOMEN AND FEMINIST LAWMAKING 112-47 (2000) [hereinafter SCHNEIDER (2000)] (discussing efforts to enable battered women to present their abuse circumstances at trial); Elizabeth M. Schneider, Equal Rights to Trial for Women: Sex Bias in the Law of Self-Defense, 15 HARV. C.R.-C.L. L. REV. 623, 632 (1980) [hereinafter Schneider (1980)] (discussing problems with the application of the equal force rule and imminent danger rules in battered women cases). Schneider previously criticized the imminence requirement not as a formal rule, but because its focus upon the immediate circumstances tended to disadvantage women by preventing them as an evidentiary matter from presenting a complete picture of the history of abuse. See Schneider (1980), supra, at 634-35. Schneider appears not to object to the requirement of imminence as long as the defendant is permitted to use evidence of prior abuse to show the reasonableness of her perception of an imminent threat. See SCHNEIDER (2000), supra, at 124 ("Evidence of battering in a self-defense case is not relevant to justify the killing, but it provides the jury with the appropriate context in which to decide whether a woman's apprehension of imminent danger of death or great bodily harm was reasonable."). Similarly, Mahoney argues, and Maguigan agrees, that evidence of "separation assault," where women who attempt to leave abusive relationships face an increased likelihood of violence from their batterers, would help battered women meet the imminence requirement. See Holly Maguigan, Battered Women and Self-Defense: Myths and Misconceptions in Current Reform Proposals, 140 U. PA. L. REV. 379, 449 (1991) (advocating retention of the imminence requirement, with use of "separation assault" evidence to satisfy the requirement); Mahoney, supra note 5, at 83-93 (explaining "separation assault" phenomenon and arguing that evidence of separation assault helps satisfy the imminence requirement).

15. Rosen, supra note 5, at 380-410.

16. Rosen's approach typifies the common desire among commentators to expand continually, without ever restricting, the legal theories available for battered women who 
This Article explores the use of necessity as the prevailing standard in all cases, permitting a claim of self-defense whenever the defendant had an objectively reasonable belief that her use of force was necessary. In this respect, the approach that I advocate is an expansion of current self-defense norms for the defendant who reasonably believes that force is necessary absent an imminent threat. However, the defendant who claims self-defense must be treated (and judged) as a rational actor. Under the rational actor approach, whether a defendant's belief is reasonable must be determined in light of her objective individual circumstances, not from her own psychologically-individualized perspective. In support of this approach to the reasonableness inquiry, I defend the objectivesubjective dichotomy and respond to Victoria Nourse's recent claim that self-defense law has always used "subjective" standards. ${ }^{17} \mathrm{By}$ insisting upon an objective standard of reasonableness, the rational actor approach is a contraction of self-defense norms for the defendant whose use of force is "reasonable" only through the distorted lens of a claimed psychological abnormality such as battered woman syndrome. ${ }^{18}$ The rational actor approach would not only lead to different results than the prevailing battered woman syndrome theory approach, but would also accomplish the discursive shift sought by feminist writers like Schneider, Mahoney, and Maguigan. The rational actor approach to understanding battered women and self-defense treats battered women as autonomous, competent decision makers and recognizes their necessary uses of force as justified, not merely excused. ${ }^{19}$

kill. Rosen recommends abrogation of the imminency requirement only if the defendant first meets an initial burden of production by presenting substantial evidence that the killing was necessary despite the absence of an imminent danger. If the defendant fails to meet that standard, she would then be permitted to use the battered woman syndrome theory in an attempt to meet the usual self-defense standards, including the requirement of imminency. See id. at $405-07$.

17. See V.F. Nourse, Self-Defense and Subjectivity, 68 U. CHI. L. REv. 1235, 1292 (2001).

18. See infra Section II.B.

19. Because modern criminal law acquits both excused and justified actors, the distinction between justification and excuse defenses has lost much of its historical practical significance. Nevertheless, the distinction retains its conceptual importance and remains a vital strain of the scholarly literature. See generally Joshua Dressler, Justifications and Excuses: A Brief Review of the Concepts and the Literature, 33 WAYNE L. REV. 1155, 1157-67 (1987) (surveying theories of justification and excuse); Kent Greenawalt, The Perplexing Borders of Justification and Excuse, 84 COLUM. L. REV. 1897, 1908 (1984) (exploring distinctions between defenses of justification and excuse); Jerome Hall, Comment on Justification and Excuse, 24 AM. J. COMP. L. 638, 638-45 (1976) (contrasting Anglo-American law and German law regarding justification and excuse); 
Whereas both Rosen and battered woman syndrome theorists view their positions as expansions of traditional self-defense standards ${ }^{20}$ this Article argues that necessary uses of force by battered women can be justified by realigning, rather than expanding, the right to use defensive force. The current standard for self-defense correlates only imperfectly with necessary uses of force. In other words, the standard sometimes punishes acts that are necessary, and sometimes exculpates acts that are not. Accordingly, I argue that changing the rules of self-defense to encompass more accurately the standard of necessity is simply a realignment, and not an expansion, of the right to defensive force. The battered woman syndrome theory, in contrast, has the potential to expand significantly the application of self-defense by excusing unnecessary killings, simply because they were committed by sympathetic actors.

My analysis unfolds in three sections. Section I provides an overview of the battered woman syndrome theory, which forms the basis for the current model of advocacy on behalf of battered women who kill. In Section II, I argue that the battered woman syndrome theory has been accepted not for its scientific or analytical validity but to attempt to accomplish two goals: (1) to counter "popular myth" about battered women ${ }^{21}$ by providing a non-demonizing explanation for battered women who stay in abusive relationships, and (2) to accommodate the self-defense claims of sympathetic domestic violence victims who kill during non-confrontational moments. As part of this argument, I first summarize the scientific and analytical

Paul H. Robinson, $A$ Theory of Justification: Societal Harm as a Prerequisite for Criminal Liability, 23 UCLA L. REV. 266, 274-79 (1975) (discussing the interplay between excuse and justification). Put generally, an excuse operates as a defense when something about the actor relieves him of moral culpability, even though his act was objectively wrong. For example, the defense of insanity excuses acts that are socially harmful, because the insane actor should not be blamed for causing the harm. In contrast, a justification defense applies when the act itself is not wrongful in light of the circumstances under which it was committed. See infra notes 142-45 and accompanying text for further discussion of the distinction between justification and excuse and the proper classification of self-defense between these options.

20. See supra notes 14-16 and accompanying text.

21. One aspect of Lenore Walker's research on domestic violence that does find empirical support is her claim that the general public believes a group of "myths" that collectively perpetuate the erroneous belief that domestic violence victims bring on their own abuse. See LenOre Walker, The BatTered Woman 18-31 (1979) [hereinafter WALKER (1979)]. Although the myths are becoming less popular as public awareness of domestic violence grows, see infra notes 368-69 and accompanying text, Walker wrote in 1979 that it was common to believe that domestic violence was rare and affected only isolated demographic groups, and that battered women were masochistic. See WALKER (1979), supra, at 19-20, 21-23. 
flaws in the prevailing explanation for battered women who kill, and note that courts have not subjected the battered woman syndrome theory to the same level of scrutiny as other scientific evidence under Daubert v. Merrell Dow Pharmaceuticals, Inc. ${ }^{22}$ Second, I observe a reluctance to extend the battered woman syndrome theory to the defense of duress, where the theory would operate to excuse battered women who commit crimes against innocent parties at the command of their batterers. That the syndrome theory has been controversial in duress cases, and yet widely accepted in the self-defense context, despite its analytical and scientific flaws, suggests that the battered woman syndrome has been used to reach a desired result of assisting battered women who kill their batterers. ${ }^{23}$

In Section III of the Article, I set out what I call a rational actor approach to understanding the effects of domestic violence and argue that this approach satisfies the normative concerns that motivate the support for the battered woman syndrome theory in the self-defense context. I then use the rational actor approach to reconcile the existing tension between the treatment of battered women in the selfdefense and duress contexts.

\section{OVERVIEW OF THE BATTERED WOMAN SYNDROME AND ITS APPLICATION TO CLAIMS OF SELF-DEFENSE}

Widely credited with the identification of the battered woman syndrome, psychologist Lenore Walker has attempted not only to develop a definition by which we should identify the battered woman, ${ }^{24}$ but also to summarize a collection of attributes coined

22. 509 U.S. 579 (1993).

23. See infra Section II.B.

24. Walker defined a battered woman broadly in her landmark 1979 book as a woman who is repeatedly subjected to any forceful physical or psychological behavior by a man in order to coerce her to do something he wants her to do without concern for her rights. Battered women include wives or women in any form of intimate relationships with men. Furthermore, in order to be classified as a battered woman, the couple must go through the battering cycle at least twice. Any woman may find herself in an abusive relationship with a man once. If it occurs a second time, and she remains in the situation, she is defined as a battered woman.

WALKER (1979), supra note 21, at xv. Walker eventually expanded her definition of the battered woman to those who had experienced emotional, but not physical, abuse. LENORE E. WALKER, TERRIFYING LOVE 102 (1989) ("[W]e consider a woman to be battered if she is subjected repeatedly to coercive behavior (physical, sexual, and/or psychological) by a man attempting to force her to do what he wants her to do...."). 
"battered woman syndrome," which she alleges to be common characteristics shared by the survivors of domestic violence. ${ }^{25}$

\section{A. The Prevailing View of the Battered Woman}

Although not universally embraced by legal commentators, ${ }^{26}$ Walker's description of battered women and her labeling of them as syndromatic has found widespread acceptance. For example, the theory is taught to counselors, police officers, prosecutors, parole board officials, and social-service providers to improve the quality of their responses to domestic violence. ${ }^{27}$ In an unusual expansion of resources to assist indigent criminal defendants, the federal government at one time funded the development of training materials to facilitate the use of expert testimony regarding battered woman syndrome in criminal cases. ${ }^{28}$

25. See WALKER (1979), supra note 21, at 31-35. Walker's work has been described, for example, as identifying "a series of common characteristics that appear in women who are abused physically and psychologically over an extended period of time by the dominant male figure in their lives." State v. Kelly, 478 A.2d 364, 371 (N.J. 1984).

26. See, e.g., Robert F. Schopp et al., Battered Woman Syndrome, Expert Testimony, and the Distinction Between Justification and Excuse, 1994 U. ILL. L. REV. 45, 54-55 (criticizing Walker's research because of its lack of control groups, use of self-reporting survey data, and lack of support in data for some of the conclusions drawn from them); David L. Faigman, Note, The Battered Woman Syndrome and Self-Defense: A Legal and Empirical Dissent, 72 VA. L. REV. 619, 630-43 (1986) (critiquing Walker's research on battered woman syndrome).

27. Michael Coronado, Study Links Inmates to Abuse Syndrome: A Hemet Woman's Research Shows How Domestic Violence Results in Women Going to Prison, PRESSENTERPRISE (Riverside, Ca), Feb. 1, 2001, at B1, 2001 WL 5303217 (reporting that parole board officials received training regarding the battered woman syndrome); Stephen Hunt, $\$ 200,000$ Grant Will Help Combat Violence at Home, SALT LAKE TRIB., June 24, 1996, at D1, 1996 WL 3037424 (announcing city's receipt of grant to hire an expert in domestic violence to train police officers to recognize battered woman syndrome); Marty Sabota, Grant to Help Officers Deal with Rape Victims, SAN ANTONIO EXPRESS-NEWS, May 23, 1997, at B2, 1997 WL 3175624 (reporting then-Governor George W. Bush's approval of grants to pay for law enforcement training regarding violence against women, including the battered woman syndrome).

28. The Battered Women's Testimony Act of 1992 directed the State Justice Institute to develop training materials to assist battered women and their advocates to use expert testimony regarding the battered woman syndrome "in appropriate cases, particularly appropriate cases involving indigent women defendants" and to assist potential experts regarding the syndrome to develop skills that facilitate the providing of expert testimony. Battered Women's Testimony Act of 1992, Pub. L. No. 102-527, § 2, 106 Stat. 3459, 3459 (1992) (codified at 42 U.S.C. $\$ 10702(2000)$ ); see also President's Statement on Signing the Battered Women's Testimony Act of 1992, 1992-93 PUB. PAPERS 2028, 2028-29 (Oct. 27, 1992), reprinted in 1992 U.S.C.C.A.N. 3016, 3016 (Presidential Paper of George H.W. Bush, announcing the signing of the Battered Women's Testimony Act of 1992). 
Two components of Walker's battered woman syndrome theory are the "cycle theory of violence" 29 and "learned helplessness," "two separate psychological theories used both to describe and to explain the phenomenon of ongoing domestic violence. There is a common perception that the victims of domestic violence can simply leave an abusive relationship if they do not like it. ${ }^{31}$ To proponents of the battered woman syndrome theory, the cyclical nature of domestic violence and a victim's learned helplessness work hand-in-hand to answer one of the most commonly asked questions about domestic violence: When a woman is abused by a lover or spouse, why doesn't she just leave?

The cycle theory of violence purports to describe three distinct phases of what supposedly can be characterized as a typical battering relationship. The "tension building phase" begins with verbal bickering and lower-level physical and emotional abuse and continues with increasing tension between the batterer and victim. ${ }^{32}$ This phase is followed by the "acute battering incident," exemplified by the batterer's uncontrollable explosions of violence. ${ }^{33}$ Following the batterer's uncontrollable rage is the "loving contrition phase," when the batterer calms, demonstrates his love, pleads for forgiveness, and promises never to hit again. ${ }^{34}$ The contrition stage is said to weaken the battered woman's resolve to terminate the abusive relationship

29. For a discussion of the cycle theory of violence, see WALKER (1979), supra note 21, at 55-70, and LenORE E. WALKer, THE BATTERED WOMAN SYNDROME 95-104 (1984) [hereinafter WALKER (1984)].

30. See WALKER (1979), supra note 21, at 43-54 (explaining the social learning theory of "learned helplessness").

31. State v. Kelly, 478 A.2d 364, 377 (N.J. 1984); see also Joan H. Krause, Of Merciful Justice and Justified Mercy: Commuting the Sentences of Battered Women Who Kill, 46 FLA. L. REV. 699, 712 (1994) (suggesting that it is often difficult for juries to understand why women fail to leave abusive relationships). Martha Mahoney's retelling of one trial court judge's expressed skepticism of a battered woman's claimed defense demonstrates that this oversimplification of the dynamics of a violent relationship goes beyond lay jurors: "The reason I don't believe it is because I don't believe anything like this could happen to me. If I was [sic] you and someone had threatened me with a gun, there is no way that I could continue to stay with them [sic]." Martha R. Mahoney, Victimization or Oppression? Women's Lives, Violence, and Agency, in THE PUBLIC NATURE OF PRIVATE VIOLENCE 59, 73 (Martha Albertson Fineman \& Roxanne Mykitiuk eds., 1994) (quoting Maryland judge Roslyn Smith in RePORT OF THE SPECIAL COMMITTEE ON GENDER BIAS IN THE COURTS, 2-3 (1989)).

32. WALKER (1984), supra note 29 , at $95-96$.

33. Id.

34. $I d$. 
and reinforce her beliefs that the situation will change. ${ }^{35}$ Inevitably, however, tensions begin to build and the cycle soon repeats itself. ${ }^{36}$

Even if accurate, the cycle theory of violence only explains why a woman stays around to be hit more than once. It does not explain why she would remain in a violent relationship for more than a few rotations of the theorized cycle. Well-deserved skepticism generally falls on both the makers of failed promises and those who profess continued belief in them. Battered women who stay are plagued not only by this general inclination to see a liar's believer as gullible or even blameworthy, ${ }^{37}$ but also by what Walker calls the "popular myths" specifically about battered women. ${ }^{38}$ According to Walker, lay people commonly believe "that battered women are masochistic, that they stay with their mates because they like beatings, that the violence fulfills a deep-seated need within each partner, or that they are free to leave such relationships if that is what they really want." ${ }^{39}$

To answer the question of why a battered woman remains in an abusive relationship, Walker relies on the theory of "learned helplessness." ${ }^{40}$ Walker's theory is an extension of the theory originally proposec by Martin Seligman, who found in experiments that caged dogs subjected to inescapable electrical shock eventually stopped attempting to escape, even when given escape opportunities. ${ }^{41}$ Walker borrows Seligman's research and analogizes

35. Id

36. Id. at 96 .

37. Consider, for example, the popular maxim, "Fool me once, shame on you; fool me twice, shame on me."

38. Walker et al., supra note 6, at 1-2.

39. Id.

40. WALKER (1984), supra note 29, at 86; see, e.g., Ibn-Tamas v. United States, 407 A.2d 626, 634 (D.C. 1979) (recounting Walker's testimony regarding women who stay in abusive relationships); State v. Kelly, 478 A.2d 354, 372 (N.J. 1984) (outlining factors that keep women in abusive relationships); State v. Koss, 551.N.E.2d 970, 973-74 (Ohio 1990) (discussing the use of expert testimony on battered woman syndrome to counter popular misconceptions).

41. See, e.g., Martin Seligman et al., Alleviation of Learned Helplessness in the Dog, 73 J. ABNORMAL PSYCHOL. 256, 256-62 (1968) (studying methods for treating maladaptive passive behavior in dogs). Seligman administered inescapable electrical shock to four caged dogs. Id. at 260 . When the dogs discovered the futility of their attempts to escape their cages, they began to submit without resistance. Id. The dogs' exposure to intermittent shock, without the ability either to escape or to prevent the shock, eventually rendered them "helpless." Id. The dogs failed to respond even when given an opportunity to escape. Id. The researchers then attempted to retrain the dogs to exercise control over their environments. Id. at 260-61. The researchers' first attempt at treatment was to call to the dogs through the escape route, attempting to draw the dogs' attention to it. Only one of the four subject dogs responded to this treatment. Id. at 260. The three remaining dogs learned to escape only after being pulled to safety by the researchers 20 , 
the dogs' predicament to that of a battered woman who suffers repeated and random abuse. ${ }^{42}$ According to Walker, the "women's experiences of the noncontingent nature of their attempts to control the violence," over time, produced learned helplessness and diminished the women's "motivation to respond."43 Syndrome theorists believe that repeated domestic violence diminishes the battered woman's motivation to respond and instills in her a negative belief about the efficacy of her actions. ${ }^{44}$ Because battered women perceive their escape attempts to be futile, the theory goes, they have decreased motivation to attempt to avoid violence.

Beyond this hypothesized reduction in motivation, Walker goes still further and opines that battered women also have impaired escape skills and become incapable of recognizing their escape options. ${ }^{45}$ Walker speculates that the battered woman develops heightened survival skills and becomes hyperalert to her environment in an attempt to prevent further violence. ${ }^{46}$ Unfortunately, the development of her survival skills comes at the expense of escape skills. ${ }^{47}$ Walker's version of "learned helplessness" describes the battered woman as suffering from a diminished cognitive capacity to perceive the possibility of success and an inability to visualize alternatives to the battering relationship. ${ }^{48}$

35 , and 50 times, respectively. Id. at 261. 88.

42. WALKER (1979), supra note 21 , at $44-54$; WALKER (1984), supra note 29 , at $87-$

43. WALKER (1984), supra note 29 , at 87 . As one court summarized the impact of repeated physical abuse,

The battered woman often does not know why she is beaten on any particular occasion. The violence is perceived by the woman as "random and aversive stimulation." Because of its randomness, she believes she is incapable of doing anything to prevent the abuse and, as a result, feels helpless. Women who attempt to defend themselves usually succeed only in eliciting laughter from the batterer and/or provoking more abuse, accentuating the feeling of helplessness.

People v. Aris, 264 Cal. Rptr. 167, 178 (Cal. Ct. App. 1989).

44. As Walker, Thyfault, and Browne explain this extension of Seligman's theory, "battered women suffer from the same distortions in perception. A battered woman often believes that the batterer is omnipotent, that no one can help her, and thus she limits the number of responses she feels are possible or safe to make." Walker et al., supra note 6, at $8-9$.

45. WALKER (1984), supra note 29 , at $33,87-89$.

46. Id.

47. Id.

48. WALKER (1979), supra note 21, at 49-50. Walker writes,

Thus, in applying the learned helplessness concept to battered women, the process of how the battered woman becomes victimized grows clearer. Repeated batterings, like electrical shocks, diminish the woman's motivation to respond. She becomes passive. Secondly, her cognitive ability to perceive success is changed. She does not believe her response will result in a favorable outcome, 


\section{B. Battered Woman Syndrome and Self-Defense}

In light of the most common forms of female violence, it is not surprising that the social science theory of the effects of domestic violence on its survivors first emerged as a legal issue in the context of criminal defenses. When women kill, their husbands and boyfriends are usually involved, either as co-defendants or victims. ${ }^{49}$ The original use of the battered woman syndrome theory as a component of a criminal defense was to benefit women who were accused of killing their batterers. The syndrome theory was perceived as enabling domestic violence victims to claim self-defense when the traditional contours of the defense might otherwise preclude its availability. ${ }^{50}$

whether or not it might. Next, having generalized her helplessness, the battered woman does not believe anything she does will alter any outcome, not just the specific situation that has occurred. She says, "No matter what I do, I have no influence." She cannot think of alternatives. She says, "I am incapable and too stupid to learn how to change things." Finally, her sense of emotional well-being becomes precarious. She is more prone to depression and anxiety.

Id. In light of Walker's explicit description of battered women as cognitively impaired, it is surprising that Walker subsequently criticized feminists who were concerned that Walker's work depicts battered women as "helpless." See LENORE E.A. WALKER, THE BATTERED WOMAN SYNDROME 116 (2d ed. 2000) [hereinafter WALKER (2000)] (dismissing the criticism of the learned helplessness theory as "a good lesson in battered women's feminist politics").

49. At one point, more than two thirds of the women on death row in the United States either killed their husbands or lovers or killed in cooperation with them. Victor $\mathrm{L}$. Streib, Death Penalty for Battered Women, 20 FLA. ST. U. L. REv. 163, 186 (1992).

50. The issue of the battered woman syndrome theory arises in two separate procedural contexts. The defendant may rely on the theory to support her request for a jury instruction regarding self-defense, even though her case does not appear to fit within traditional self-defense requirements. See, e.g., State v. Gallegos, 719 P.2d 1268, 1268 (N.M. Ct. App. 1986) (holding that defendant had produced sufficient evidence to warrant jury instruction regarding self-defense), overruled on other grounds by State v. Alberico, 861 P.2d 192, 201 (N.M. 1993); State v. Norman, 324 N.C. 253, 260-66, 378 S.E.2d 8, 13-16 (1989) (rejecting defendant's attempt to use battered woman syndrome evidence to expand right to self-defense and holding that, even considering the evidence concerning the syndrome, the trial court's refusal to instruct jury on self-defense was not error, because victim was asleep at time of offense). Moreover, the defendant may seek to introduce expert testimony regarding the theory to support her self-defense claim. See, e.g., People v. Torres, 488 N.Y.S.2d 358, 358-59 (N.Y. Sup. Ct. 1985) (holding that expert testimony on battered woman syndrome was admissible where defendant shot her husband three times as he sat in a chair in their apartment); Betchel v. State, 840 P.2d 1, 910 (Okla. Crim. App. 1992) (holding that the trial court erred in not allowing battered woman syndrome testimony); State v. Felton, 329 N.W.2d 161, 172-73 (Wis. 1983) (holding that battered woman syndrome testimony could be offered where defendant shot her sleeping husband). 


\section{Traditional Elements of Self-Defense}

Although formulations of self-defense vary among jurisdictions, the general doctrine is well-known: the law exonerates the actor who harms another to defend himself from unlawful force. ${ }^{51}$ In most jurisdictions, physical force is justified if the actor reasonably believes that the force is necessary to prevent an imminent threat of unlawful physical force..$^{52}$ Two requirements suggested by this common formulation have been hurdles for the self-defense claims of some battered women who kill. First, the perceived threat must be imminent. ${ }^{53}$ An abstract fear of an undefined, future threat does not suffice. Some jurisdictions require that the threat be of "immediate" harm, narrowing the inquiry to the particular encounter. ${ }^{54}$ Second, the belief that such a threat exists must be reasonable. ${ }^{55}$ This standard requires not only that the actor in fact believe that imminent danger warrants defensive force, but also that the circumstances be such that the "reasonable person" would share this belief. ${ }^{56}$ A minority of jurisdictions add a duty to retreat to create a third requirement that the actor pursue any reasonable opportunity to retreat safely from the threat of unlawful force..$^{57}$

Note that nothing about the traditional formulation of the selfdefense doctrine necessarily requires specialized evidence pertaining to domestic violence whenever its survivors use force against their batterers. This critical but obvious point too often goes overlooked.

51. See generally DRESSLER, supra note 4, at 221-23 (discussing background and basic applications of the self-defense doctrine); LAFAVE, supra note 4, at 491 (same).

52. See LAFAVE, supra note 4, at 491.

53. See DRESSLER, supra note 4, at 221-23.

54. See, e.g., Collier v. State, 275 So. 2d 364, 367 (Ala. Crim. App. 1973) (holding that the threat must "present impending peril" to justify physical response); People v. White, 414 N.E.2d 196, 200 (Ill. App. Ct. 1980) (stating that the validity of a self-defense claim should be determined by examining "the evidence of what transpired during the 'particular instant' in which the death was caused").

55. See Swann v. United States, 648 A.2d 928, 930 (D.C. 1994); People v. Goetz, 497 N.E.2d 41, 47-48 (N.Y. 1986). See generally DRESSLER, supra note 4, at 222-23 (discussing the reasonableness requirement of the self-defense doctrine).

56. See, e.g., State v. Mendoza, 258 N.W.2d 260, 272 (Wis. 1977) (explaining that one must reasonably believe that defensive force is necessary to prevent imminent death or great bodily harm). See generally LAFAVE, supra note 4, at 493-95 (describing the objective test of reasonableness).

57. See LAFAVE, supra note 4, at 497-99. One commentator has observed that whether this third element should be required for a valid self-defense claim goes directly to the heart of the tension underlying the law of self-defense: "On one hand, an individual should be encouraged to retreat in order to avoid injury to herself or the aggressor. At the same time, one who is attacked should not be required to adopt a cowardly or humiliating posture." Faigman, supra note 26, at 624 n.14. 
When the facts of the case warrant a claim of self-defense as those claims are traditionally defined, a domestic violence victim is entitled to rely on the doctrine, notwithstanding the domestic relationship. A woman who shoots her abusive husband while he is trying to stab her should encounter no hurdle to a self-defense claim, with or without the use of social science theories regarding the effects of domestic violence. ${ }^{58}$

Walker became a hot ticket on the expert circuit ${ }^{59}$ because a small number of sympathetic women killed their very unsympathetic abusers under circumstances that, when viewed narrowly, did not appear to support a self-defense claim. One such sympathetic defendant was JoAnn Hennum, convicted by a jury of murder after she shot her husband, Robert, and then claimed self-defense. ${ }^{60}$ Robert came home on the day of his death to find JoAnn at the stove. With apparently no basis for his anger, he pushed JoAnn and shouted, "What's for supper, bitch?"61 When he saw some leftover oatmeal on the stove, he hit JoAnn in the head with the pan. ${ }^{62}$ Awakened by his parents' fighting, one of their children saw his father dumping oatmeal on his mother. ${ }^{63}$ Undeterred by his children's presence, Robert grabbed JoAnn by the hair and began pulling her around the room, showing her cans of chili and demanding that she warm some up for him. ${ }^{64}$ When JoAnn did as commanded and began to prepare the chili, Robert went after her again, throwing her to the floor and ripping her shirt. ${ }^{65}$ Whenever JoAnn fell, Robert would grab her hair and pull her back up. ${ }^{66}$ At one point, Robert had her pinned to the floor with his hands on her throat. ${ }^{67}$ Despite JoAnn's efforts to placate her husband, Robert's violence toward her escalated. When Robert finally went into the living room and left her

58. See Dressler, supra note 9, at 265 (noting that Judy Norman would have a straightforward self-defense claim and would not need to rely on evidence of the battered woman syndrome if she had shot her husband while he was beating her with a baseball bat).

59. For example, in retaining Lenore Walker to act as an expert member of the O.J. Simpson dream team, attorney Johnnie Cochran praised Walker as the "mother of battered women's syndrome." See David Margolick, Simpson's Lawyer Tells Jury That Evidence "Doesn't Fit," N.Y. TIMES, Sept. 28, 1995, at A1.

60. See State v. Hennum, 441 N.W.2d 793 (Minn. 1989).

61. Id. at 795 .

62. Id.

63. Id.

64. Id.

65. Id.

66. Id.

67. Id. 
alone, JoAnn continued her attempts to cook dinner for him. But Robert inexplicably threw a piece of firewood and then a car part at her. ${ }^{68}$ JoAnn tried to protect herself by hiding under the kitchen table, but Robert grabbed a rocking chair and threw it at her so violently that it broke. ${ }^{69}$ The abuse continued until Robert eventually went into the bedroom and fell asleep. ${ }^{70}$

This was not the first time that Robert had abused his wife. According to defense evidence, Robert abused JoAnn and their children throughout the marriage, sending her to the hospital for a punctured lung, ruptured spleen, and broken nose. ${ }^{71}$ When his fists did not suffice, Robert resorted to steel-toed boots and broken bottles. $^{72}$ Joanne finally acted to end the abuse. She testified at her trial that after Robert went to sleep, she noticed a gun lying on the floor with a bullet sticking out of it. ${ }^{73}$ She loaded the bullet into the gun and decided to scare her husband. ${ }^{74}$ She testified that "she went into the bedroom, closed her eyes, and fired the gun." 75

The lurid facts of JoAnn Hennum's abuse are worth belaboring because these are the kinds of facts that have fueled the desire to facilitate the self-defense claims of battered women. Judy Norman, perhaps the most frequently cited example of a battered woman who killed her husband, faced even more horrific abuse. ${ }^{76}$ Norman was a thirty-nine year old woman whose husband of twenty-five years subjected her to a life of forced prostitution and appalling physical abuse. ${ }^{77}$ Norman attempted to leave the abusive relationship several times, only to be brought back to further and escalating abuse. ${ }^{78}$ Norman recently had looked into having her husband committed and applying for social service benefits to support herself. ${ }^{79}$ Norman's husband interrupted her appointment to apply for benefits, brought her home, and told her he would kill her if she ever tried to leave him again or if he saw anyone coming for him. ${ }^{80}$ When her husband got

68. Id. at 795-96.

69. Id. at 796 .

70. $I d$.

71. Id. at 795 .

72. $I d$.

73. $I d$. at 796 .

74. $I d$.

75. Id.

76. For a complete rendition of the facts, see State v. Norman, 324 N.C. 253, 256-57, 378 S.E.2d 8, 8-11 (1989).

77. Id. at 255,378 S.E. $2 \mathrm{~d}$ at 10 .

78. Id. at 257,378 S.E.2d at 11 .

79. Id.

80. $I d$. 
drunk and fell asleep, Norman retrieved a gun from her mother's house and shot him. ${ }^{81}$

The prototypical lethal self-defender acts during a "kill or be killed" moment. In both Hennum and Norman, the batterers were sleeping, not wielding weapons or punching with fists, when the defendants decided to act. A battered woman who kills during a nonconfrontational moment encounters two related problems when claiming self-defense-the requirement of imminence and her failure to leave the relationship. Even as a purely subjective test, the requirement that the defendant actually believe that she faced an imminent attack can be difficult to meet when her victim was currently docile, no matter how temporary that status. ${ }^{82}$ Jurors might simply disbelieve the defendant's testimony that she subjectively believed that an attack was imminent. That the prevailing standard of imminence is an objective one presents an even greater hurdle. Even if the jury believes that the defendant feared an imminent attack, that fear looks unreasonable given the break in the violence.

A second problem is that jurors may ask why the battered woman did not leave her husband, either while he was sleeping or earlier, and reject the claim of self-defense without a satisfactory answer. In jurisdictions that impose a duty to retreat, ${ }^{83}$ a battered woman's failure to leave during a non-confrontational moment can be fatal to a claim of self-defense. Even in the majority of jurisdictions that do not impose such a duty, juror intuitions about domestic

81. Norman was convicted after the trial court refused to deliver a jury instruction regarding self-defense. Id. at 254,378 S.E.2d at 9 . Although an intermediate appellate court reversed Norman's conviction and held that the self-defense instruction was warranted in light of expert testimony regarding battered woman syndrome and learned helplessness, the Supreme Court of North Carolina affirmed the conviction and held that any instruction regarding self-defense would have been error, because the defense had not satisfied the requirement of imminence. Id. at 266,378 S.E.2d at 16.

82. The Model Penal Code recommends relaxation of the imminence standard by requiring the defensive actor to believe that his use of force is "immediately necessary for the purpose of protecting himself against use of unlawful force by such other person on the present occasion." MODEL PENAL CODE § 3.04(1) (1985). Under this approach, an actor can use force in the absence of an imminent threat, as long as the force is necessary to preempt a future attack. See GlanViLle Williams, TeXtBook of CRiminal Law 503 ( $2 \mathrm{~d}$ ed. 1983) ("The use of force may be immediately necessary to prevent an attack in the future."). Although the Model Penal Code standard of immediate necessity is more generous to the defensive actor than the requirement of an imminent threat, even the more generous standard does not fully help the battered woman who might have been able to act at some later date but still needed to act inevitably. Cf. Dressler, supra note 9 , at 275 (arguing that the Model Penal Code's standard of immediate necessity strikes a "suitable compromise" between the imminency requirement and complete elimination of a temporal-based rule).

83. See infra notes 293-304 and accompanying text. 
violence victims may achieve the same result. Jurors may conclude on their own that a battered woman is not justified in using force after she has chosen to remain in a relationship with a long history of abuse. For example, a misplaced jury theory of assumption of the risk could prevent jurors from applying the self-defense doctrine to battered women. Similarly, a jury may be reluctant because of issues of credibility to acquit a defendant who stayed within what she describes in her testimony as a violent relationship. In light of the defendant's failure to leave the relationship, jurors may disbelieve the victim's account of prior abuse or may conclude that the woman participated in or even enjoyed the abuse.

\section{The Resort to the Battered Woman Syndrome Theory}

Advocates of the battered woman syndrome theory argue that it supports the self-defense claims of battered women who kill during non-confrontational moments. The cycle theory of violence ${ }^{84}$ has been offered to explain why the battered woman believed that her temporarily-docile abuser presented a threat of imminent harm when she attacked him. The theory of learned helplessness ${ }^{85}$ has been offered to explain why the woman remained in the abusive relationship.

Expert testimony describing the cycle theory is said to explain the reasonableness of a domestic violence victim's perception that serious harm was "imminent" despite the fact that her abuser was seemingly calm or even sleeping when she killed him. ${ }^{86}$ According to battered woman syndrome theorists, the cyclical nature of domestic violence causes a battered woman's perception of danger to extend beyond the time of a particular battering episode. ${ }^{87}$ Thus, the woman

84. For a discussion of the cycle theory of violence, see WALKER (1979), supra note 21, at 55-70, and WALKER (1984), supra note 29, at 95.

85. See generally WALKER (1979), supra note 21, at 45-50 (describing the theory).

86. See Ibn-Tamas v. United States, 407 A.2d 626, 634 (D.C. 1979) (stating that testimony regarding battered woman syndrome provides "a basis from which the jury could understand why [the defendant] perceived herself in imminent danger at the time of the shooting"); State v. Kelly, 478 A.2d 364, 377 (N.J. 1984) ("[E]xpert's testimony, if accepted by the jury, would have aided it in determining whether, under the circumstances, a reasonable person would have believed there was imminent danger to her life."); State v. Kelly, 685 P.2d 564, 570 (Wash. 1984) (allowing expert testimony "offered to aid the jury in understanding the reasonableness of [the defendant's] apprehension of imminent death or bodily injury").

87. State v. Hodges, 716 P.2d 563, 567 (Kan. 1986), overruled by State v. Stewart, 763 P.2d 572 (Kan. 1988) (noting that battered women "live in constant fear of another eruption of violence"); State v. Norman, 324 N.C. 253, 270-271, 378 S.E.2d 8, 18-19 (1989) (Martin, J., dissenting) (setting forth the argument that battered women suffer from a 
lives under a constant reign of terror and may kill during an apparently peaceful moment out of fear that she will not be able to protect herself from the next, inevitable attack.

The cycle theory of violence is said to help jurors not only to weigh the credibility of a domestic violence victim's account of subjective fear, but also to determine whether the defendant had an objectively reasonable belief that harm was imminent. ${ }^{88}$ If the jury is permitted to consider expert testimony summarizing the cycle theory of violence and its impact on the battered woman, the argument goes, then the jury may conclude that a reasonable person in the battered woman's position would have perceived an imminent threat of harm, despite the apparent peacefulness of the current situation. ${ }^{89}$

Standing alone, however, the cycle theory of violence might not suffice to make a self-defense claim available to battered women who kill during a non-confrontational moment. Even if the defendant convinces a jury that she reasonably believed that harm was imminent, the jury may be reluctant to acquit based on what Walker calls the "popular myths" that plague women who remain in abusive relationships. ${ }^{90}$ To explain to jurors why a battered woman remains in an abusive relationship, courts have permitted expert testimony concerning Walker's theory of learned helplessness. ${ }^{91}$

According to Walker's theory of learned helplessness, the battered woman's responses must be seen as consequences of the woman's attempts to cope with the abusive and controlling

perpetual fear of "imminent" danger).

88. Norman, 324 N.C. at 270-71, 378 S.E.2d at 18-19 (Martin, J., dissenting) (arguing that defendant should have received a self-defense instruction, because jurors could have found that defendant's fear of an imminent threat from her sleeping husband was reasonable in light of evidence that she suffered from battered woman syndrome theory).

89. See Kelly, 478 A.2d at 377 (stating that evidence of battered woman syndrome theory would have helped the jury determine whether a reasonable person would have perceived an imminent danger); Kelly, 685 P.2d at 570 (same).

90. See WALKER (1979), supra note 21 , at 18-31; Walker et al., supra note 6, at 1-2. According to Walker, society often misinterprets the survival skills of battered women as signs of passivity and weakness coupled with an unwillingness to leave the violent relationship. WALKER (1979), supra note 21, at 33. A common misunderstanding is that the battered woman's responses are indicative of weak character, leading to the "popular myths" about battered women. See id. at 18-31; Walker et al., supra note 6, at 1-2. See supra notes 37-39 and accompanying text for further discussion of "popular myths."

91. See, e.g., Ibn-Tamas, 407 A.2d at 638-39 (holding that the trial court erred in excluding Walker's testimony); Kelly, 478 A.2d at 372, 381 (ruling that admission of battered woman syndrome evidence would help jurors to understand "the unique pressures that force battered women to remain with their mates"); State v. Koss, 551 N.E.2d 970, 973 (Ohio 1990) (permitting the admission of evidence of battered woman syndrome to assist the jury in determining whether the defendant had reasonable grounds for believing she was in imminent danger). 
environment in which she lives and feels helpless to escape. ${ }^{92}$ The battered woman fails to leave not because she wants to stay, but because she lacks the cognitive capacity to appreciate her escape options. ${ }^{93}$

\section{FLAWS IN THE BATTERED WOMAN SYNDROME THEORY}

Although the battered woman syndrome theory has been embraced overwhelmingly by courts, domestic violence advocates, and many legal commentators, the theory suffers from critical flaws. As an initial matter, the empirical research underlying the theory does not withstand scrutiny. Moreover, even if the syndrome is accepted as an accurate description of the battered woman, the description ultimately fails to support the extension of self-defense to even the most justified uses of force unless there is an imminent threat of abuse.

This section of the Article explores the flaws in the battered woman syndrome theory and argues that the widespread acceptance of the theory-despite its obvious flaws-suggests that the theory has been embraced to achieve the desired end result of assisting sympathetic battered women whose self-defense claims would otherwise fail. That the theory has largely been confined to the selfdefense context, despite its logical extension to the defense of duress, further supports this conclusion.

\section{A. Flawed Research on Battered Woman Syndrome}

In determining whether courts' enchantment with the battered woman syndrome theory is warranted, an initial consideration is whether expert testimony regarding the syndrome is admissible even as an evidentiary matter. Daubert $v$. Merrell Dow Pharmaceuticals, Inc. ${ }^{94}$ drastically altered the rules governing the admissibility of expert opinion testimony. Prior to Daubert, the admission of scientific evidence was typically governed by the "general acceptance" test under Frye v. United States. ${ }^{95}$ Under Frye, the battered woman syndrome theory's popularity among social scientists would alone warrant introduction of expert testimony about the theory into evidence. ${ }^{96}$ In Daubert, however, the Court rejected the "general

92. WALKER (1979), supra note 21 , at $49-50$.

93. Id.

94. 509 U.S. 579 (1993).

95. 293 F. 1013 (D.C. Cir. 1923).

96. One might speculate whether the social science community's acceptance of the battered woman syndrome theory is the chicken or the egg to its acceptance in court. In 
acceptance" test and set forth a nonexhaustive, multi-factor list for determining whether expert testimony regarding a theory or technique is admissible. ${ }^{97}$

That Daubert was expected to expand the admissibility of novel scientific evidence is beyond question. ${ }^{98}$ When the Court rejected the Frye standard, it did so in favor of "a flexible one," consistent with the "liberal thrust" of the Federal Rules of Evidence and their "general approach of relaxing the traditional barriers to 'opinion' testimony."

their review of the scientific literature related to battered woman syndrome theory, Schuller and Vidmar report that the American Psychological Association, in endorsing the validity of the battered woman syndrome theory in its amicus brief in State v. Kelly, 478 A.2d 364 (N.J. 1984), noted the considerable recognition of the theory in the legal community. Regina A. Schuller \& Neil Vidmar, Battered Woman Syndrome Evidence in the Courtroom, 16 LAw \& HuM. BeHAV. 273, 279 (1992). Despite which community's acceptance of the theory came first, there is general agreement among courts that the battered woman syndrome theory is generally accepted by social scientists. See Nixon v. United States, 728 A.2d 582 (D.C. 1999), cert. denied 528 U.S. 1098 (2000) (holding expert testimony about the battered woman syndrome to be admissible under Frye); State v. Hickson, 630 So. 2d 172, 175 (Fla. 1993) ("Because the scientific principles underlying expert testimony relative to the battered woman's syndrome are now firmly established and widely accepted in the psychological community, we conclude that the syndrome has now gained general acceptance in the relevant scientific community as a matter of law.") (quoting Rogers v. State, 616 So. 2d 1098 (Fla. Dist. Ct. App. 1993), overruled on other grounds by State v. Hickson, 630 So. 2d 172 (Fla. 1993)); Kelly, 478 A.2d at 378 (concluding that the battered woman syndrome theory had gained general acceptance); People v. Torres, 488 N.Y.S.2d 358, 363 (N.Y. Sup. Ct. 1985) (holding that battered woman syndrome had gained "substantial enough scientific acceptance to warrant admissibility"); State v. Allery, 682 P.2d 312, 316 (Wash. 1984) (holding that expert testimony regarding the battered woman syndrome theory was admissible where state rules of evidence required general acceptance).

97. Daubert, 509 U.S. at 593-94. The Daubert factors are (1) whether a theory or technique can be and has been tested; (2) whether the theory or technique has been subjected to peer review and publication; (3) the known or potential rate of error; and (4) whether the theory or technique finds "general acceptance" in the relevant scientific community. Id.

98. Commentators both for and against the new Daubert standard assumed that it would increase litigants' ability to introduce expert opinion evidence. Proponents praised the death of Frye as a tribute to the liberal approach of the Federal Rules of Evidence. 3 JACK B. Weinstein \& MARGARET A. BERGER, WEINSTEIN's EVIDENCE II 702[03], at 702-46 ("[T]he silence of [Rule 702] and its drafters [regarding the Frye standard] should be regarded as tantamount to an abandonment of the general acceptance standard."). Opponents predicted that any change from Frye to a more flexible standard would only increase the pedaling of "junk science." See Peter W. Huber, Galileo's Revenge: JUNK SCIENCE IN THE COURTROOM 3 (1991); Samuel R. Gross, Expert Evidence, 1991 WIS. L. REV. 1113, 1116.

99. Daubert, 509 U.S. at 594.

100. Id. at 588 (quoting Beech Aircraft Corp. v. Rainey, 488 U.S. 153, 169 (1988) (citing Rules 701 to 705 of the Federal Rules of Evidence)). 
Surprisingly, however, courts are increasingly stressing their role as "gatekeepers" against unreliable expert testimony, applying Daubert's multi-factor test to exclude evidence that they deem to be invalid and unreliable. ${ }^{101}$ Courts that value their role as gatekeepers against unreliable scientific evidence more than the flexibility underlying the Federal Rules of Evidence have routinely secondguessed the conclusions of would-be expert witnesses and have held, for example, that published case reports, animal studies, and nonepidemiological studies are unreliable, even though these forms of study may generally be acceptable in the scientific community. ${ }^{102}$ Invoking Daubert, one lower court momentarily went so far as to exclude expert opinion testimony about the matching of fingerprints. ${ }^{103}$

The new emphasis under Daubert upon scientific validity raises serious questions about the admissibility of the battered woman syndrome theory, regardless of its "general acceptance" among social scientists. My purpose in this Article is not to resolve this evidentiary question, ${ }^{104}$ but simply to note that the battered woman syndrome

101. The second-guessing of scientists that has become common in lower courts was not wholly uninvited by the Supreme Court, despite its repeated references to flexibility. For example, in Daubert, Justice Blackmun noted that, if anything, the differences between the quest for truth in the courtroom and the quest for truth in the laboratory require more certainty in court than is customary in the scientific world. Id. at 597-98. Because of the differences between the lab and the courtroom, the Court noted "a gatekeeping role for the judge" that would "inevitably on occasion ... prevent the jury from learning of authentic insights and innovations." Id.

102. See, e.g., Gen. Elec. Co. v. Joiner, 522 U.S. 136, 145-47 (1997) (affirming exclusion of non-epidemiologic causation evidence and exclusion of statistically insignificant epidemiologic evidence); Raynor v. Merrell Pharms., Inc., 104 F.3d 1371, 1375 (D.C. Cir. 1997) ("The only way to test whether data from non-human studies can be extrapolated to humans would be to conduct human experiments or to use epidemiological data."); Willert v. Ortho Pharm. Corp., 995 F. Supp. 979, 981 (D. Minn. 1998) (noting problems of using case reports to prove causation); Casey v. Ohio Med. Prods., 877 F. Supp. 1380, 1385 (N.D. Cal. 1995) ("[C]ase reports are not reliable scientific evidence of causation.").

103. United States v. Llera Plaza, Cr. No. 98-362-10, 2002 WL 27305 (E.D. Pa. Jan. 7, 2002), vacated, 188 F. Supp. 2d 549 (applying Daubert factors to exclude opinion testimony regarding whether an individual's known fingerprint matches a latent fingerprint, despite the general acceptance of such evidence in the scientific community). Weeks later, the district court vacated its initial decision and held that Daubert had not gone so far. United States v. Llera Plaza, 188 F. Supp. 2 d 549 (E.D. Pa. 2002).

104. Commentators who have set out to resolve whether Walker's theory meets evidentiary thresholds for admissibility under Daubert have reached varied conclusions. Compare David Faigman \& Amy Wright, The Battered Woman Syndrome in the Age of Science, 39 ARIZ. L. REV. 67, 109-10 (1997) (concluding that evidence of the battered woman syndrome theory lacks reliability required by Daubert), and Janet C. Hoeffel, The Gender Gap: Revealing Inequities in Admission of Social Science Evidence in Criminal Cases, 24 U. ARK. LiTTLE ROCK L. REV. 41, 48-51 (2001) (same), with Kelly Grace Monacella, Comment, Supporting a Defense of Duress: The Admissibility of Battered 
theory has enjoyed more unquestioned acceptance than it should, particularly in light of recent scrutiny of expert testimony generally. ${ }^{105}$

As an initial matter, there is good reason for trial courts to be skeptical of Walker's research. The Supreme Court has instructed trial courts "to make certain that an expert, whether basing testimony upon professional studies or personal experience, employs in the courtroom the same level of intellectual rigor that characterizes the practice of an expert in the relevant field."106 Some have even suggested that the primary purpose of the Daubert reliability factors is to provide assurances that an expert's intellectual rigor is not abandoned for litigation purposes. ${ }^{107}$

Walker is admittedly an advocate with understandable and even laudable sympathy for battered women. ${ }^{108}$ Walker has shown a

Woman Syndrome, 70 TEMP. L. REV. 699, 722-24 (1997) (asserting that evidence of the battered woman syndrome satisfies Daubert requirements), and Krista L. Duncan, Note, "Lies, Damned Lies, and Statistics?" Psychological Syndrome Evidence in the Courtroom After Daubert, 71 IND. L.J. 753, 766 (1996) (concluding that "evidence regarding the battered woman syndrome is based on scientific knowledge" under Daubert). Others have argued that evidence of the battered woman syndrome theory should be admitted, even though the theory may not meet the reliability standards required by Daubert. E.g., Laura Etlinger, Social Science Research in Domestic Violence Law: A Proposal to Focus on Evidentiary Use, 58 ALB. L. REV. 1259, 1287-88 (1995) (arguing that the admissibility of expert testimony in the area of social sciences should be based on the nature and use for which the evidence is offered and on whose behalf the evidence is offered); Allison Morse, Social Science in the Courtroom: Expert Testimony and Battered Women, 21 HAMLINE L. REV. 287, 295-321 (1998) (arguing that expert testimony regarding battered woman syndrome should be permitted because it is based on expertise beyond the general knowledge of jurors, even though not always based on the scientific method).

105. See Hoeffel, supra note 104, at 50-51 (noting that courts have not reevaluated the admissibility of the battered woman syndrome theory in light of Daubert).

106. Kumho Tire Co. v. Carmichael, 526 U.S. 137, 152 (1999).

107. One writer has suggested that courts should simply use this as the standard for determining the admissibility of expert testimony. See J. Brook Lathram, The "Same Intellectual Rigor" Test Provides an Effective Method for Determining the Reliability of All Expert Testimony, Without Regard to Whether the Testimony Comprises "Scientific Knowledge" or "Technical or Other Specialized Knowledge," 28 U. MEM. L. REV. 1053, 1055 (1998); see also Wessman v. Gittens, 160 F.3d 790, 805 (1st Cir. 1998) (noting that an expert witness who departs from the accepted methods of scientific inquiry that he usually employs in his work must have grounds for doing so that are consistent with the methods, practices, and usages of his scientific community); Braun v. Lorillard, Inc., 84 F.3d 230, 234 (7th Cir. 1996) (same); Allen v. Pa. Eng'g Corp., 102 F.3d 194, 198 (5th Cir. 1996) ("[T]he goal of Daubert and this court's previous cases has been to bring more rigorous scientific study into the expression of legal opinions offered in court by scientific and medical professionals."). As Judge Posner has asked, "why should a court rely on the sort of exposition the scholar would not tolerate in his professional life?" Rosen v. CIBA-Geigy Corp., 78 F.3d 316, 319 (7th Cir. 1996) (quoting Mid-State Fertilizer Co. v. Exch. Nat'l Bank, 877 F.2d 1333, 1339 (7th Cir. 1989)).

108. See WALKER (1984), supra note 29, at $\mathrm{x}$ ("It is foolish for academicians and professionals to stand behind the cloak of objectivity in a field of study as politicized as 
willingness to testify in support of the battered woman in even the most extreme cases and appears to see no limits to the definition of imminence. ${ }^{109}$ One court has stated that Walker's testimony during witness voir dire suggested that she "may make certain conclusions and state certain theories, then engage in research to attempt to substantiate those theories and conclusions." 110

For example, Walker offered to testify for the defendant in State v. Martin, ${ }^{111}$ who hired a hit man to kill her husband after he left her to live with another woman. After the hit man shot Martin's husband, Martin complained that her husband was not dying fast enough and ordered him to shoot again. Satisfied that her husband was finally dead, the defendant left for a friend's birthday party. ${ }^{112}$ Walker's willingness to claim that even Martin acted in self-defense suggests that she simply wants to help battered women, regardless of the applicability of social science. ${ }^{113}$

Furthermore, the empirical evidence that claims to support Walker's theory of battered woman syndrome is problematic at best. As an initial matter, Walker's selection of subjects is at once both too

this.").

109. See Faigman, supra note 26, at 630-32. Curiously, Walker was retained to assist the defense of O.J. Simpson, arguably the most infamous of accused batterers. See Margolick, supra note 59 (noting O.J. Simpson defense team's retention of Lenore Walker as an expert). She was not, however, called as a testifying witness, and one member of the "dream team" has confirmed the impression that the "dream team" paid a retainer to Walker as a "preemptive step" so the prosecution could not take advantage of her services. See Nicolas Lemann, Trial and Error, N.Y. TIMES, Mar. 3, 1996, \& 7 (Magazine), at 7 (reviewing Alan M. Dershowitz, Reasonable DoubTs: THE O.J. Simpson CASE AND THE CRIMINAL JUSTICE SYSTEM (1996)).

110. Buhrle v. State, 627 P.2d 1374, 1377 (Wyo. 1981).

111. 666 S.W.2d 895, 897 (Mo. Ct. App. 1984).

112. Id. The defendant was convicted of capital murder and sentenced to life imprisonment. Id. The appellate court held that it was not error to exclude Walker's testimony, because evidence of the battered woman syndrome would not establish that defendant's fears were reasonable or that the decedent presented any imminent threat of harm. Id. at 898-99.

113. Put as a matter of credibility rather than motivations, "[t]hat the leading theoretician of battered woman syndrome would be willing to characterize Martin as a case of legitimate self-defense seems to call into question the credibility of her testimony in other cases." Faigman, supra note 26, at 632 . Martin is not the only case that stretches Walker's credibility. For example, Walker offered to testify on behalf of Edith Buhrle, even though Buhrle killed her husband after she took rubber gloves and a rifle to the motel where he was staying while he filed for divorce, and then claimed that someone else had done it. Buhrle, 627 P.2d at 1376-78. Walker offered to testify that Buhrle suffered from battered woman syndrome, that learned helplessness impaired the defendant's ability to walk away or escape a situation, that the defendant perceived herself to be acting in self-defense, and that her belief was reasonable. Id. Apparently in forming her opinion, Dr. Walker did not take into account the fact that defendant took a gun and gloves with her to the motel and then hid them afterward. Id. at 1377. 
narrow and too broad. All of her subjects were battered women, with no control group for comparison against women who had never been abused. ${ }^{114}$ On the other hand, few of her subjects killed their abusers, and apparently none were accused of committing criminal behavior in cooperation with their abusers. ${ }^{115}$ Because the principal application of Walker's data is to battered women who are accused of violating the law, one would think that she would have designed her study to look at differences not only between battered and non-battered women, but also between battered women who use force and battered women who do not. ${ }^{116}$

David Faigman has thoroughly explored how additional flaws in Walker's research design call into question the validity of her theories of both learned helplessness and the cycle theory of violence. ${ }^{17}$ Walker's theory of learned helplessness is primarily an extension of Seligman's research on dogs. ${ }^{118}$ Her sole empirical evidence for this extension is that women currently in abusive relationships are more fearful, anxious, and depressed, and less angry, disgusted, and hostile than women no longer in battering relationships. ${ }^{119}$ Although the six variables she chose to measure may correlate with learned helplessness, nothing suggests that these are valid diagnostic indicators of the phenomenon. ${ }^{120}$

114. See WALKER (1984), supra note 29, at 203 (faulting problems of "time and expense" for failure to utilize control groups that are commonly perceived as necessary in epistemological research).

115. Walker reveals that nine of her fifty subjects killed their batterers, but she does not mention whether any of them were accused of committing crimes in cooperation with their batterers. Id. at 40 .

116. See Faigman, supra note 26, at 642-43 (criticizing Walker's failure to compare battered women who killed to other battered women). In more recent research, Elizabeth Leonard summarizes characteristics of women imprisoned for killing abusive husbands or boyfriends. ElizabeTH Dermody LeONARD, CONvicted SuRvivors: The IMPRISONMENT OF BATTERED WOMEN WHO KILL 57-69 (2002). Although Leonard compares these women to the general population of women in prison, she does not compare them to battered women who survived abuse without using deadly force. See id. at 60 (comparing women convicted of killing abusive partners with the broader population of female inmates).

117. For the complete version of Faigman's scathing critique of Walker's research, see Faigman \& Wright, supra note 104, at 86-89, and Faigman, supra note 26, at 636-43. See also Schopp et al., supra note 26, at 54-65 (criticizing Walker's research because of its lack of control groups, use of self-reporting survey data, and lack of support in data for some of the conclusions drawn from them).

118. See supra notes $41-44$ and accompanying text.

119. WALKER (1984), supra note 29 , at $86-89$.

120. Faigman, supra note 26, at 641-42. Moreover, for each subject, Walker clumped together the scores for fear, anxiety, and depression and for anger, disgust, and hostility; she did not measure these traits individually. The resulting "clump" score says little about the traits as a group, because a high score may simply reflect a high score for a single trait. 
Faigman also critiques Walker's methodology for her cycle theory of violence, which Walker tested by interviewing battered women about four battering incidents: the first, the second, one of the worst, and the most recent. ${ }^{121}$ Faigman notes five general problems permeating Walker's protocol. First, Walker's interviewers used leading questions. ${ }^{122}$ Leading questions can lead to hypothesisguessing in subjects, provoking them to answer as they believe the experimenter wishes. ${ }^{123}$ Second, evidence of the various cycles came from the interviewers' evaluation of subject responses, not from the subjects themselves. ${ }^{124}$ This aspect of Walker's procedure opens the door to experimenter expectancies. ${ }^{125}$

A third problem with Walker's research is that her questions do not place the cycle of violence within any time frame. It is unclear whether the tension-building stage typically lasts ten minutes or several days. She simply states that the three stages exist in a cycle. She also does not explore whether a fourth stage of normality exists between a batterer's phase of loving contrition and the next tensionbuilding phase, or whether the stages of the cycle mutate during the relationship. ${ }^{126}$ For example, research building on Walker's work suggests that what Walker describes as the contrition stage disappears over time in many battering relationships, and is wholly nonexistent in others. ${ }^{127}$

A fourth problem is that no empirical evidence supports the extension of the hypothesized cycle of violence to Walker's claim that battered women therefore live in "cumulative terror." 128 Although a disturbing number of Walker's subjects thought that their husbands

Walker also failed to test the statistical significance of the differences between currently and formerly battered women and cited apparently de minimis differences as support for her theory. Id. at 642 .

121. As Walker describes the procedure:

After the description of each incident, basing her judgment on both the openended description and a series of closed-ended questions concerning the batterer's behavior before the event .... and after the event .... the interviewer recorded whether or not there was "evidence of tension building and/or loving contrition."

WALKER (1984), supra note 29 , at 96.

122. Faigman, supra note 26 , at 637 . For example, subjects were asked whether their abusers acted "nice, loving, [and] contrite" after battering incidents. WALKER (1984), supra note 29 , at 96 .

123. Faigman, supra note 26, at 637.

124. Id.

125. Id. at $637-38$.

126. Id. at 638 .

127. See Schuller \& Vidmar, supra note 96 , at 280.

128. Faigman, supra note 26 , at 638-39. 
were capable of killing them, fewer than half indicated so unequivocally. ${ }^{129}$ Significant numbers of subjects indicated that their husbands would be capable of killing them only if "mad enough" or "accidentally."130 At least for these subjects, then, there were moments within an abusive relationship that were not plagued by fears of imminent death, indicating that not all battered women live in a constant state of fear.

Faigman's fifth criticism of Walker's research calls into question whether the cycle even exists. Walker concluded that each of the three stages in the cycle was prevalent in a majority of her subjects. According to her data, sixty-five percent of the batterings were preceded by a period of tension building and fifty-eight percent were followed by a phase of loving contrition. However, Walker does not provide data exploring what percentage of her subjects experienced all three cycles. Based on Walker's data, the number of women experiencing all phases could be as low as twenty-three percent and, in any event, no higher than fifty-eight percent. ${ }^{131}$

Though fifteen years have passed since Faigman's initial critique of Walker's research, the battered woman syndrome enjoys continued popular support with little change in the empirical landscape during the intervening years. ${ }^{132}$ The discrepancy between the theory's

129. WALKER (1984), supra note 29 , at 177 . Walker's subjects were asked, "Did you think he ever would or could kill you?" Forty-eight percent said "[y]es," twenty-six percent answered, "[y]es, if mad enough," twelve percent said, "[y]es, accidentally," six percent stated, "[m]aybe," and eight percent said, "[n]ever." Id.

130. Id.

131. Faigman, supra note 26 , at 639-40. The low end of this range would exist if all 35 percent of Walker's subjects who did not experience a tension-building phase were among the 58 percent of subjects who did experience a contrition phase, leaving just 23 percent who experienced both phases. The high end of this range would exist if all of the 58 percent of subjects who experienced the contrition phase were among the 65 percent who reported a tension-building phase. Id.

132. As Faigman and Wright report, empirical research since Faigman's initial critique in 1986 has failed to yield additional support for Walker's cycle and learned helplessness theories. Faigman \& Wright, supra note 104, at 75 ("Surprisingly, no proponent of the battered woman syndrome has responded to this methodological critique leveled in 1986. Moreover, although significant amounts of excellent research have been done in the last decade, none of it has obtained results that support the hypothesis of the battered woman syndrome."). For example, Walker's updated edition of The Battered Woman Syndrome relies upon her original data to support the cycle theory and learned helplessness theories. WALKER (2000), supra note 48, at 116-38. Although a student note concludes that "later studies have confirmed much of Walker's theory," the conclusion does not find support in the literature. See Duncan, supra note 104, at 765 . For example, the author cites a study finding in battered women "a cluster of serious disorders ... including major depression, post traumatic stress disorder, generalized anxiety disorder, and obsessive compulsive disorder," which reportedly "seem related to the battered woman syndrome described by Walker." Id. at 765 n.117 (citing Walter J. Gleason, Mental Disorders in Battered Women: 
scientific and popular support may not indicate a generally poor ability to analyze empirical research as much as the existence of some other basis for the popular support of the battered woman syndrome theory. Before turning to that possibility, other problems with the battered woman syndrome theory are explored.

\section{B. Poor Fit Between the Battered Woman Syndrome Theory and Self-Defense}

In addition to legitimate questions regarding the reliability of Walker's empirical research is the issue of the "fit" between Walker's theory and the disputed issues in a trial of a domestic violence victim who kills during a non-confrontational situation and then claims selfdefense. Even if scientific evidence is reliable, it is admissible only if it logically advances a material issue in dispute. ${ }^{133}$ The fit between Walker's syndrome theory and the traditional elements of selfdefense is imperfect at best.

Although the cycle theory of violence, if true, arguably explains why a battered woman's perception of danger might extend beyond a specific assault, it does not follow from the cycle theory that the woman's perception of an imminent harm is reasonable, even viewed from her distorted perspective. In light of the three distinct phases of the domestic violence cycle, the cycle theory itself seems to require knowledge of where the battered woman's allegedly defensive use of force fell within the cycle and how long each distinct phase typically lasted before one can determine the reasonableness of the perception of imminent harm. For example, if Judy Norman's husband had become contrite and apologetic immediately before he fell asleep intoxicated, it would follow from the cycle theory of violence that there was no imminent threat of harm-and no reasonable belief

An Empirical Study, 8 ViolenCE \& Victims 53, 62 (1993)). This observation says nothing about Walker's critical cycle theory and learned helplessness hypotheses. Moreover, the author cites as support Schuller and Vidmar's literature review, even though the authors note that the cycle pattern of violence and learned helplessness find less empirical support than other components of battered women's circumstances and situations. See Schuller \& Vidmar, supra note 96, at 280-81.

133. Daubert v. Merrell Dow Pharm., Inc., 43 F.3d 1311, 1315 (9th Cir. 1995) (Daubert II). Looking to the text of Rule 702, the Supreme Court held in Daubert that the district court's role is to ensure that all scientific testimony and evidence offered in federal court is not only relevant but also reliable. Daubert v. Merrell Dow Pharm., Inc., 509 U.S. 579, 584 (1993). A determination of relevance requires the court to examine the "fit" between the scientific evidence and the disputed issues in the case to determine whether the proffered evidence logically advances a material aspect of the party's case. Daubert $I I, 43$ F.3d at 1315 . 
otherwise-until the contrition phase was complete and the tensionbuilding phase was well under way.

Even if the battered woman syndrome theory were helpful in supporting a domestic violence victim's account of her subjective perceptions, the theory does little to support a claim that such perceptions were objectively reasonable. When an actor subjectively but unreasonably believes that her use of force is justified, she has at best a claim of imperfect self-defense, which mitigates punishment but does not wholly exculpate. ${ }^{134}$ The advocates of the battered woman syndrome theory argue that the jury must determine whether a "reasonable battered woman" would have perceived a threat of imminent harm, and that expert testimony is necessary for the jury to understand the reasonable battered woman. ${ }^{135}$ From this perspective, then, the syndrome evidence is relevant to a contextualized standard of reasonableness, where the model for comparison is a reasonable person with the defendant's characteristics. ${ }^{136}$ Not even under a contextualized standard of reasonableness, however, has the criminal law ever accepted the notion of a psychologically-individualized objective standard. ${ }^{137}$ Although an actor's objective circumstances can sometimes be considered to determine whether a reasonable person would share the actor's perceptions, the law does not accept as

134. See, e.g., In re Christian S., 872 P.2d 574, 576 (Cal. 1994) (explaining that any honestly held belief of imminent peril negates the mens rea of malice, and that the reasonableness of the honest belief goes only to the justification of the act). The Model Penal Code's approach to self-defense codifies this approach by limiting the scope of liability to reckless or negligent homicide when an actor subjectively believes that his use of deadly force is justified, but his belief is reckless or negligent. See MODEL PENAL CODE $\$ 3.09$ (2) (1985). In many jurisdictions, however, a consequence of the requirement of an objectively reasonable belief in justification is that the actor's recklessness or even negligence in forming this belief altogether strips him of any self-defense claim. See id. $\S 3.04$.

135. See, e.g., Smith v. State, 486 S.E.2d 819, 823 (Ga. 1997) (finding that evidence of the battered woman syndrome helps the defendant show that her beliefs were objectively reasonable from the perspective "of a reasonable person possessing the same or similar psychological and physical characteristics as the defendant").

136. See generally Jody D. Armour, Race Ipsa Loquitur: Of Reasonable Racists, Intelligent Bayesians, and Involuntary Negrophobes, 46 STAN. L. REV. 781, 799 (1994) (describing "the widely accepted" standard for reasonableness that takes into account the defendant's past experiences as the doctrinal foundation for race-based self-defense claims); Kevin Jon Heller, Beyond the Reasonable Man? A Sympathetic but Critical Assessment of the Use of Subjective Standards of Reasonableness in Self-Defense and Provocation Cases, 26 AM. J. CRIM. L. 1, 80-98 (1998) (describing a "particularized" reasonableness standard); Mark Kelman, Reasonable Evidence of Reasonableness, 17 CRITICAL INQUIRY 798, 798-817 (1991) (exploring the qualification of reasonableness standards with group-based characterizations).

137. See Dressler, supra note 9 , at 269 (noting that a "reasonable" person who misperceives reality is a contradiction). 
reasonable a perception attributable to the defendant's own unique psychological abnormality. ${ }^{138}$ Otherwise, the objective standard of reasonableness would become wholly subjective. For example, under a psychologically-individualized standard of reasonableness, the paranoid schizophrenic who crushes an innocent woman's skull with a brick $^{139}$ or throws her onto the subway tracks ${ }^{140}$ would be entitled to a claim of self-defense on the basis that any "reasonable paranoid schizophrenic" would have believed that the victim was about to kill him. Even qualified standards of reasonableness have never been extended to include psychologically-individualized standards of objectivity. ${ }^{141}$

Indeed, altering the self-defense standard to accommodate an actor's personal psychology undermines the very notion of selfdefense as a justification. ${ }^{142}$ Justification defenses operate when the

138. People v. Romero, 81 Cal. Rptr. 2d 823, 827 (Cal. Ct. App. 1999) (rejecting expert testimony opining that poverty and Latino culture of paternalism by an older brother justified the defendant's use of force to protect his younger brother); State v. Hampton, 558 N.W.2d 884, 889-91 (Wis. Ct. App. 1996) (excluding from self-defense case psychosocial evidence of ghetto background of violence and fear).

139. This hypothetical is based upon two highly-publicized New York incidents involving random street attacks. Paris Drake was sentenced to 25 years imprisonment after he was convicted of shattering a woman's skull with a brick in a random street attack. In reality, Drake claimed mistaken identity, not self-defense. See Katherine E. Finklestein, Man Convicted of Midtown Brick Attack Gets Maximum Sentence of 25 Years, N.Y. TIMES, Dec. 14, 2000, at B3. The suspect arrested in a second similar attack had a long history of mental problems and confessed to the assault, but was later released after a store's surveillance tapes established an alibi for him. See Katherine E. Finklestein Prosecutors Detail Evidence Leading to Suspect's Release, N.Y. TIMES, July 27, 2000, at B3.

140. This hypothetical is based upon Andrew Goldstein, a man with a long psychiatric record who pushed a young woman to her death onto the New York City subway tracks. See Michael Winerip, Oddity and Normality Vie in Subway Killer's Confession, N.Y. TIMES, Oct. 18, 1999, at B1. Goldstein confessed to the crime and did not claim selfdefense. $I d$.

141. See Ha v. State, 892 P.2d 184, 195-96 (Alaska Ct. App. 1995) ("The reasonableness of a defendant's perceptions and actions must be evaluated from the point of view of a reasonable person in the defendant's situation, not a person suffering mental dysfunction."); State v. Cole, 755 A.2d 202, 210-11 \& n.24 (Conn. 2000) (holding that a defendant who claimed that, because of a mental defect, he honestly but irrationally believed he was acting in self-defense could not have claimed self-defense; the actor's belief must be objectively reasonable); People v. Goetz, 497 N.E.2d 41, 47-51 (N.Y. 1986) (noting that defendant's beliefs must have a reasonable basis when viewed objectively and cannot be based upon fancy or delusion); State v. Jeppesen, 776 P.2d 1372, 1375-76 (Wash. App. 1989) (ruling that a defendant did not raise a valid self-defense claim, because his subjective belief that police officers were Russian agents who were pursuing him was not objectively reasonable).

142. See generally Dressler, supra note 9, at 267 (arguing that syndrome evidence speaks to an actor's mental state, not to her act, and is therefore consistent with notions of excuse, not justification); Cathryn Jo Rosen, The Excuse of Self-Defense: Correcting a 
defendant's act is the morally preferred option. ${ }^{143}$ Because justified acts are viewed as objectively preferable, the psychological, subjective peculiarities of the defendant are generally irrelevant to the application of the justification defense. ${ }^{144}$ In contrast, excuse defenses apply when the act itself is harmful, but when something about the actor relieves her of moral culpability for the wrongful act. ${ }^{145}$

The typical self-defender argues that her otherwise illegal use of force was objectively preferred under the unusual circumstances in which she found herself. In contrast, a defendant invoking the learned helplessness and cycle theory components of the battered woman's syndrome theory argues that her atypical psychology impaired her ability to ascertain the likelihood and the severity of the dangers presented by the batterer, thereby causing her to commit an undesirable act. If the basis for the defendant's decision to use force (deadly or not) is attributable to her individual psychology, the asserted theory of relief should be an excuse such as insanity or extreme emotional disturbance. Under neither theory is the defendant considered to be justified; rather, the defendant's conduct is understood not to be preferred, but merely excused in whole or in part because of the defendant's mental defect or disease.

The battered woman described by Walker would be unlikely to meet the traditional test of insanity. Judy Norman, for example, would meet neither the M'Naghten nor the Model Penal Code standards of insanity, because she clearly appreciated both the nature of her act and its criminality, and could have refrained from the conduct. ${ }^{146}$ Although Walker's version of the battered woman might

Historical Accident on Behalf of Battered Women Who Kill, 36 AM. U. L. REV. 11, 18-24 (1986) (arguing that battered woman syndrome is a disability conforming to excuse theory).

143. See, e.g., George Fletcher, Rethinking Criminal Law 769 (1978) ("The modern claim is that all justificatory arguments can be reduced to a balancing of competing interests and a judgment in favor of the superior interest."); Dan M. Kahan \& Martha C. Nussbaum, Two Conceptions of Emotion in Criminal Law, 96 COLUM. L. REV. 269,319 (1996) (describing justified acts as ones producing a "morally preferred states of affairs").

144. Kahan \& Nussbaum, supra note 143 , at 319 ; see also DRESSLER, supra note 4, at 202-03 (noting that justification claims generally focus upon the absence of any wrongfulness to the act, whereas excuses center upon the lack of moral culpability of the actor).

145. DRESSLER, supra note 4, at 202-03; Dressler, supra note 19, at 1162-63; Kahan \& Nussbaum, supra note 143 , at 319.

146. Under the M'Naghten rule, an accused is not criminally responsible if, at the time he committed the act, he was suffering from a defect of reason from disease of the mind such that he dicl not know the nature and quality of his act or did not know the wrongfulness of his act. M'Naghten's Case, 8 Eng. Rep. 718, 722 (1843). The Model Penal 
properly be considered as acting under extreme emotional disturbance, ${ }^{147}$ a claim of extreme emotional disturbance acts only to reduce murder to manslaughter. ${ }^{148}$ It is not a basis for acquittal.

Code provides that "[a] person is not responsible for criminal conduct if at the time of such conduct, as a result of such mental disease or defect he lacks substantial capacity either to appreciate the criminality [wrongfulness] of his conduct or to conform his conduct to the requirements of law." MODEL PENAL CODE $\$ 4.01$ (1985). Norman established the absence of legal insanity by testifying that when she killed her husband, she did not care whether she had to spend the rest of her life incarcerated, because it would be a better life than she had with him. State v. Norman, 324 N.C. 253, 257, 378 S.E.2d 8, 11 (1989).

147. Even with a theory of mitigation instead of defense, a battered woman who kills in response to prolonged abuse during a non-confrontational moment might have difficulty avoiding a murder conviction. At common law, provocation reduced intentional homicide to manslaughter only if there had not been a sufficient "cool down" period had not yet passed. Courts generally refuse to allow mitigation of intentional homicide where the actor has enjoyed a reasonable opportunity for his passions to cool. See Ex Parte Fraley, 109 P. 295, 297 (Okla. Crim. App. 1910); State v. Gounagias, 153 P. 9, 14 (Wash. 1915) (en banc). The Model Penal Code's expanded notion of mitigation, known as extreme emotional disturbance, does not contain an explicit "cool down" exception and requires only that the defendant act "under the influence of extreme mental or emotional disturbance for which there is reasonable explanation or excuse." MODEL PENAL CODE $\$ 210.3(1)(b)$. Accordingly, a battered woman who killed during a non-confrontational moment could have her charge reduced to manslaughter if she was still "under the influence," despite the pause in the violence, and if her disturbance was still reasonable.

148. See generally Victoria Nourse, Passion's Progress: Modern Law Reform and the Provocation Defense, 106 YALE L.J. 1331 (1997) (arguing for a more limited reconstruction of the Model Penal Code's treatment of "crimes of passion" because its current form preserves a role for gender-based norms). Although there is a reasonableness component to determining whether provocation is sufficient to reduce murder to manslaughter, the reasonableness standard in this context often provides a greater role to the subjective perceptions of the defendant. For example, the Model Penal Code provides that homicide that would otherwise be murder constitutes manslaughter when it "is committed under the influence of extreme mental or emotional disturbance for which there is reasonable explanation or excuse. The reasonableness of such explanation or excuse shall be determined from the viewpoint of a person in the actor's situation under the circumstances as he believes them to be." MODEL PENAL CODE $\$ 210.3(1)(b)$. Although the reaction of the defendant is evaluated by an objective standard, the evaluation must take the circumstances as the defendant subjectively believed them to be. In the self-defense context, however, a subjectively held, but negligent or reckless, belief about the circumstances appearing to justify defensive force prevents the doctrine from acting as a complete defense. See id. $\S 3.09(2)$ (providing that self-defense is unavailable against charges of recklessness or negligence when the actor's beliefs about the necessity of the use of force were reckless or negligent). Elizabeth Schneider has noted the disparity of the application of the provocation doctrine to male and female violence in intimate relationships. Applying concepts of justification or excuse defined by the male experience, those sitting in judgment have historically understood the motivation of a man who kills his wife out of jealousy. Battered women who kill in response to battering, however, have been treated harshly by the law. SCHNEIDER (2000), supra note 14, at 11617; see also Emily L. Miller, (Wo)manslaughter: Manslaughter, Gender, and the Model Penal Code, 50 EMORY L.J. 665 (2001) (arguing that the Model Penal Code's approach to manslaughter has worsened, not mitigated, the devaluation of women's lives reflected in 
Even setting aside the poor fit between a theory of psychological incapacitation and a legal defense of justification, Walker's battered woman syndrome ultimately iails to provide a satisfactory explanation for why the battered woman kills during a nonconfrontational moment. If one believes the cycle theory of violence, then one believes that the victim of domestic violence endures a constant and heightened fear of abuse, even if her batterer is peaceful or even sleeping. If one also believes the theory of learned helplessness, then one believes that the domestic violence victim is not only living in a constant reign of terror, but also suffering from a cognitive incapacity to recognize any method of escape. One would expect, therefore, the domestic violence victim to remain passive even when her batterer is seemingly calm or even sleeping, because she nonetheless is fearful of an imminent attack and because of her incapacity to recognize the ability to do anything other than remain passive. ${ }^{149}$

Perhaps Walker's most explicit statement on this issue is that a battered woman sometimes "strikes back during a calm period, knowing that the tension is building towards another acute battering incident, where this time she may die." 150 She speculates, "[t]he women felt that no one took them seriously, that they alone had to protect themselves against brutal attacks, and that they knew by observable changes in the man's physical or mental state that this time he really would kill them." 151 Walker's apparent rebuttal to this argument does little, however, to explain how women suddenly break from their helplessness. Moreover, although it suggests why a battered woman may feel justified in using force in the absence of an

common law voluntary manslaughter approaches).

149. Alan. M. DERShowitz, The ABuse Excuse and OTher Cop-OuTs, Sob STORIES, AND EVASIONS OF RESPONSIBILITY 15 (1994) ("The act of killing is not a symptom of the battered woman syndrome. Indeed, it is largely inconsistent with the characteristic symptoms of passivity."); CHARLES P. EWING, BATTERED WOMEN WHO KILL 56 (1987) (noting that the helplessness and passivity connoted by the battered woman syndrome creates an implicit contradiction: "if the battered woman was so helpless and passive why did she kill the batterer?"); JAMES Q. WILSON, MORAL JudGMENT: DOES THE ABUSE EXCUSE THREATEN OUR LEGAL SySTEM? 53 (1997) (noting that "killing one's abuser seems quite inconsistent with the theory of learned helplessness. Seligman's helpless dogs did not bite their abusers, but Walker's helpless women killed theirs"); Anne M. Coughlin, Excusing Women, 82 CAL. L. REV. 1, 81 (1994) ("If the woman is psychologically paralyzed, as Walker claims, then it seems much more likely that she will continue to endure the ongoing violence, rather than resort to such an extreme form of self-help.").

150. WALKER (1984), supra note 29, at 142.

151. Id. at 40 . 
imminent threat, Walker's assertion undermines the argument that battered women reasonably perceive the coming threat as imminent.

Walker's explanation is also inconsistent with her assertion that the battered woman's cognitive resources are expended upon her hyperalertness to the possibility of future violence at the expense of escape skills. Walker has difficulty explaining why the woman's cognitive priority suddenly shifts from survival skills within the abusive relationship to escape skills that require use of force to survive outside the relationship.

Walker's likely explanation for the discrepancy between the passivity connoted by the learned helplessness theory and the action necessary to act in self-defense is that the battered woman who kills does so not because of her learned helplessness, but because she has overcome it. Walker, for example, concludes that women leave abusive relationships when they become more angered, disgusted, and hostile, and less fearful, anxious, and depressed. ${ }^{152}$ Walker acknowledges, however, that her findings "do not indicate why some women become disgusted and angry enough to leave a relationship and others do not." 153 Similarly, Walker's findings fail to explain why some women kill their abusers and others remain in a battering relationship to their peril.

More importantly, though, Walker's conclusion that a woman's passivity ends when she overcomes learned helplessness does little to assist women like Norman and Hennum. If the battered woman has overcome her learned helplessness and can appreciate exit options, then the syndrome fails to explain why she exercises the option of deadly force. Additionally, if Walker's explanation for the shift from passivity to action is that the woman's emotions have shifted to anger, disgust, and hostility, then the use of force would appear to be out of revenge rather than the need for self-protection.

In sum, there is a poor fit between the battered woman syndrome theory and the self-defense claims of battered women who kill. To qualify for self-defense, the actor's belief that she faced an imminent threat must have been objectively reasonable. The battered woman syndrome theory is relevant to such a claim only if courts evaluate the battered woman's beliefs from the perspective of a reasonable person whose perceptions have been altered as a result of battered woman syndrome. This psychologically-individualized concept of

152. Id. at 89 .

153. Id. 
reasonableness has never been accepted in other contexts. ${ }^{154}$ Moreover, the battered woman syndrome theory ultimately fails to explain why a victim of domestic violence might kill in a nonconfrontational circumstance. The heightened and prolonged fear, cognitive impairment, and submissiveness described by the syndrome theory are inconsistent with a sudden decision to act at all, let alone with deadly force. If the explanation for this discrepancy is that the woman who acts has overcome her learned helplessness, then nothing about the theory exculpates.

\section{Refusal to Apply to Duress Claims Demonstrates Result-Oriented Acceptance of Theory}

Because of questions about both the reliability and relevance of Walker's research, one would expect a trend toward disallowing expert evidence regarding battered woman syndrome, at least in those courts that emphasize their role as gatekeepers about the flexibility intended by Rule 702 and Daubert. Nevertheless, evidence of the battered woman syndrome has enjoyed a lengthy love affair with most courts, social scientists, and legal commentators. ${ }^{155}$

Courts have largely ignored the flaws in the scientific research underlying the battered woman syndrome theory and have held that scientific evidence regarding the syndrome is sufficiently reliable to meet evidentiary standards. ${ }^{156}$ Additionally, because the cycle theory and the theory of learned helplessness are perceived as supporting a battered woman's claim of self-defense, a majority of jurisdictions have held that expert testimony regarding battered woman syndrome

154. See supra notes $137-41$.

155. As Faigman explains,

[c]ritical review [of battered woman syndrome research] usually focuses on the applicability of researchers' conclusions to the legal doctrine of self-defense, not on the validity of the conclusions themselves. Commentators have smoothed over the numerous analytical problems involved in applying theories of battered woman syndrome to self-defense cases, and they have wholly neglected the empirical flaws of the research.

Faigman, supra note 26, at 631; see also James Acker \& Hans Toch, Battered Women, Straw Men, And Expert Testimony: A Comment On State v. Kelly, 21 CRIM. L. BULL. 125, $139-43$ (1985) (considering accuracy of research findings).

156. See Bonner v. State, 740 So. 2d 439, 441-44 (Ala. Crim. App. 1998) (as corrected January 14, 2000) (reversing battered woman's manslaughter conviction based on trial court's rejection of expert testimony regarding battered woman syndrome, because "[a]llowing the defense the opportunity to present expert testimony on the syndrome and the characteristics of a battered woman would not have confused the jury but instead would have given the jury and the trial court information beyond the understanding of the average layperson"); see also United States v. Brown, 891 F. Supp 1501, 1506-08 (D. Kan. 1995) (holding evidence of battered woman syndrome to be admissible under Daubert). 
is relevant and admissible to assist a jury to decide whether a battered woman has a valid self-defense claim. ${ }^{157}$ Moreover, a number of state legislatures have mandated by statute that evidence regarding the battered woman syndrome meets standards of admissibility, thereby removing from the courts' hands their usual role of determining on a case-by-case basis whether expert testimony is admissible. ${ }^{158}$

157. As a leading criminal law casebook concludes, "A clear majority of states now permit the defendant to introduce expert testimony on the "battered woman syndrome." JOHN KAPLAN ET AL., CRIMINAl LAw: CASES AND MATERIALS 597 (4th ed. 2000); see, e.g., People v. Humphrey, 921 P.2d 1, 9 (Cal. 1996) (ruling that evidence regarding battered woman syndrome is admissible); Chapman v. State, 367 S.E.2d 541, 543 (Ga. 1988) (same); State v. Hundley, 693 P.2d 475, 480 (Kan. 1985) (same); State v. Anaya, 438 A.2d 892, 894 (Me. 1981) (same); Commonwealth v. Rodriquez, 633 N.E.2d 1039, 1042 (Mass. 1994) (same); State v. Hennum, 441 N.W.2d 793, 798 (Minn. 1989) (same); State v. Williams, 787 S.W.2d 308, 313 (Mo. Ct. App. 1990) (same); Boykins v. State, 995 P.2d 474, 479 (Nev. 2000) (same); State v. Kelly, 478 A.2d 364, 376 (N.J. 1984) (same); State v. Gallegos, 719 P.2d 1268, 1274 (N.M. 1986) (same) overruled on other grounds by State v. Alberico, 861 P.2d 192, 201 (N.M. 1993); People v. Torres, 488 N.Y.S.2d 358, 362 (N.Y. Sup. Ct. 1985) (same); State v. Leidholm, 334 N.W.2d 811, 819 (N.D. 1983) (same); State v. Moore, 695 P.2d 985, 987 (Or. App. 1985) (same); Commonwealth v. Stonehouse, 555 A.2d 772, 784-85 (Pa. 1989) (same); State v. Hill, 339 S.E.2d 121, 122 (S.C. 1986) (same); State v. Furlough, 797 S.W.2d 631, 649 (Tenn. Crim. App. 1990) (same); State v. Ciskie, 751 P.2d 1165, 1176-77 (Wash. 1988) (same); State v. Steele, 359 S.E.2d 558, 564 (W. Va. 1987) (same). See generally James O. Pearson, Jr., Annotation, Admissibility of Expert or Opinion Testimony on Battered Wife or Battered Woman Syndrome, 18 A.L.R. 4TH 1153 (1982) (discussing state and federal case that have considered or decided that evidence of battered woman syndrome is admissible). But see Hill v. State, 507 So. 2d 554, 555 (Ala. 1986) (rejecting admission of evidence regarding battered woman syndrome); Fultz v. State, 439 N.E.2d 659,662 (Ind. App. 1982) (upholding trial court's refusal to admit expert testimony on facts of particular case, without appearing to establish per se rule); State v. Necaise, 466 So. 2d 660, 664-65 (La. Ct. App. 1985) (rejecting admission of evidence regarding battered woman syndrome); State v. Clay, 779 S.W.2d 673 (Mo. App. 1989) (upholding trial court's refusal to admit expert testimony on facts of particular case, without appearing to establish per se rule), overruled on other grounds by J.E.B. v. Alabama ex rel. T.B., 511 U.S. 127 (1994); State v. Felton, No. 80-1458-CR, 1981 WL 138911 , at $* 17$ (Wis. App. Dec. 28, 1981) (rejecting admission of evidence regarding battered woman syndrome), aff'd in part, rev'd in part, 329 N.W.2d 161 (Wis. 1983); Buhrle v. State, 627 P.2d 1374, 1376-78 (Wyo. 1981) (affirming the exclusion of Walker's proffered testimony because defense did not lay proper foundation and Walker's opinion extended to ultimate issues to be resolved by the jury).

158. See, e.g., CAL. EvID. CoDE $\$ 1107$ (b) (West Supp. 1995) (providing that battered woman syndrome is scientifically valid and admissible when relevant and when the testifying expert is properly qualified); MD. CODE ANN., CTS. \& JUD. PROC. \$ 10-916(b) (1998) (admitting evidence of the battered woman syndrome "notwithstanding evidence that the defendant was the first aggressor, used excessive force, or failed to retreat at the time of the alleged offense”); MASS. ANN. LAwS ch. 233, \$23F (Law Co-op 1996) (allowing evidence of battered woman syndrome to be the subject of expert testimony at the trial of criminal cases "charging the use of force against another where the issue of defense of self or another, defense of duress or coercion, or accidental harm is asserted"); OHIO REV. CODE ANN. $\$ 2901.06($ A)(1)-(2) (Anderson 1996) (providing that battered woman syndrome is a "matter of commonly accepted scientific knowledge" and that "the 
The overwhelming acceptance of the battered woman syndrome theory is consistent with two possible realities. The first is that courts and legislatures may sincerely believe that the syndrome is an actual phenomenon. They permit defendants to use evidence of the syndrome because they have concluded that the evidence is relevant and reliable. Alternatively, the syndrome theory may enjoy its reverence as a result of either sympathy for battered women who kill, a lack of sympathy for the batterers who are killed, or both. That the theory's popularity far exceeds its scientific and analytical merit suggests that sympathies are the underlying driving forces. The reluctance to expand the syndrome theory to other legal contexts further suggests that the criminal justice system has relied upon the syndrome solely within the self-defense context to achieve the desired result of assisting domestic violence victims who use force against their batterers. ${ }^{159}$ This section of the Article discusses the largely unsuccessful efforts of syndrome theory advocates to expand the theory's application outside of the self-defense context.

Specifically, advocates have attempted to use the theory to help domestic violence victims who are charged with crimes not against

subject matter and details of the syndrome are not within the general understanding or experience of a person who is a member of the general populace").

159. Courts' acceptance of the prosecution's use of battered woman syndrome evidence in the prosecution of domestic violence cases is consistent with the objectives served by the evidence when used by a battered woman to support a self-defense claim. See Arcoren v. United States, 929 F.2d 1235, 1240-41 (8th Cir. 1991) (concluding that expert testimony regarding syndrome was admissible to explain the recantation of the victim-witness); State v. Borrelli, 629 A.2d 1105, 1112-14 (Conn. 1993); Nixon v. United States, 728 A.2d 582, 593 (D.C. 1999) (affirming trial court's admission of battered woman syndrome evidence to explain conduct of victim-witness in a domestic violence prosecution); Commonwealth v. Goetzendanner, 679 N.E.2d 240, 244-45 (Mass. App. Ct. 1997) (finding that evidence was admissible to explain victim's erratic behavior); People v. Christel, 537 N.W.2d 194, 196 (Mich. 1995) (holding evidence admissible to assist jury in assessing credibility of victim-witness); State v. Frost, 577 A.2d 1282, 1288 (N.J. Super. Ct. App. Div. 1990) (finding that evidence was admissible to explain the victim's delay in reporting the abuse and remaining with the defendant after the abuse); State v. Ciskie, 751 P.2d 1165, 1171 (Wash. 1988) (same). See generally Joan M. Schroeder, Note, Using Battered Woman Syndrome Evidence in the Prosecution of a Batterer, 76 IOWA L. REV. 553 (1991) (summarizing cases). When used by the prosecution against a defendant in a domestic violence case, and when used by a battered woman to support a claim of selfdefense against her batterer, evidence of the battered woman syndrome acts to assist the battered woman and punish the batterer. The reluctance to accept the syndrome theory, I argue, comes only when the evidence has implications outside the battering relationship and is offered to excuse criminal conduct affecting innocent third parties. In these instances, the proponent of the evidence asks the fact finder not to punish the batterer or to excuse a battered woman from killing her batterer, but to excuse a battered woman who has committed crimes against third parties on the basis that she-like the third party victims that she has harmed-is a victim of the batterer. 
their batterers, but against third parties in cooperation with their batterers. In recent years, defendants have attempted to invoke battered woman syndrome to excuse drug-related crimes, ${ }^{160}$ embezzlement, ${ }^{161}$ fraud, ${ }^{162}$ bank robbery, ${ }^{163}$ and murder, ${ }^{164}$ arguing that the conduct should be excused because it was done only to appease an abusive husband or boyfriend. In these cases, defendants have attempted to borrow the analysis that has been well accepted in the self-defense context to expand the defense of duress beyond its traditional application. ${ }^{165}$ In these instances, the proponent of the evidence asks the fact finder not to excuse a battered woman from killing her batterer, but to excuse a battered woman who has committed crimes against third parties on the basis that she-like the third party victims that she has harmed-is a victim of the batterer.

160. See, e.g., United States v. Archer, No. 91-50743, 1993 U.S. App. LEXIS 24875, at *5-6 (9th Cir. Sept. 23, 1993) (manufacture and possession of methamphetamine with intent to distribute); United States v. Santos, 932 F.2d 244, 246-47 (3d Cir. 1991) (distribution of cocaine); United States v. Sixty Acres in Etowah County, 930 F.2d 857, 860 (11th Cir. 1991) (forfeiture of co-owned property purchased with the proceeds of drugdealing); United States v. 38011 Moravian, No. 89-CV73098-DT, 1991 U.S. Dist. LEXIS 14358, at *2-3 (E.D. Mich. June 19, 1991) (same).

161. See, e.g., United States v. Sebresos, No. 91-10193, 1992 U.S. App. LEXIS 17757, *6-8 (9th Cir. July 22, 1992) (holding that battered woman syndrome cannot be a defense to charges of embezzlement).

162. See, e.g., United States v. Homick, 964 F.2d 899, 906 (9th Cir. 1992) (forged phony affidavit).

163. See, e.g., United States v. Thomas, 11 F.3d 1392, 1399 (7th Cir. 1993) (aiding and abetting armed robbery by driving getaway car); United States v. Simpson, 979 F.2d 1282, 1288 (8th Cir. 1992) (same).

164. See, e.g., People v. Smith, 608 N.E.2d 1259, 1270 (Ill. App. Ct. 1993) (defendant killed three month old son by forcing caustic substance down his throat); State v. Bockorny, 863 P.2d 1296, 1300 (Or. Ct. App. 1993) (defendant and husband both had forced intercourse with victim before stabbing and strangling her, then threw the body over an embankment); see also Cox v. State, 843 S.W.2d 750, 755-56 (Tex. App. 1992) (conspiracy to commit murder).

165. See, e.g., Homick, 964 F.2d at 905 (invoking duress defense against charges of fraud); Sixty Acres in Etowah County, 930 F.2d at 857 (invoking duress defense in forfeiture action); Neelley v. State, 642 So. 2d 494, 505 (Ala. Crim. App. 1993) (claiming abuse by husband prevented defendant from forming intent to murder). It is also common for defendants to argue that their status as battered women entitles them to a lighter sentence once convicted of the offense. See, e.g., United States v. Johnson, 956 F.2d 894, 901 (9th Cir. 1992) (affirming conviction for drug offense but remanding for resentencing) supplemented on reh'g sub nom., United States v. Emelio, 969 F.2d 849 (9th Cir. 1992); see also U.S. SENTENCING GUIDELINES MANUAL § 5K2.12 (2001) [hereinafter U.S.S.G.] (permitting downward departure if defendant committed offense "because of serious coercion, blackmail or duress, under circumstances not amounting to a complete defense"); Laurie Kratky Dore, Downward Adjustment and the Slippery Slope: The Use of Duress in Defense of Battered Offenders, 56 OHIO ST. L.J. 665, 732-33 (1995) (arguing that courts should consider duress to mitigate the sentences of battered women who commit crimes with their batterers). 
Although some courts have permitted defendants to introduce evidence of the battered women syndrome in support of their claims of duress to excuse crimes against third parties, ${ }^{166}$ the criminal justice system has demonstrated far more skepticism of the theory-and less sympathy for domestic violence victims-in the duress context than in the self-defense arena. ${ }^{167}$ Analyzed closely, though, the battered woman syndrome theory is actually more descriptive of the battered woman who submits to her batterer's requests, however unlawful, than one who uses force against him. The only apparent explanation for accepting the theory in the self-defense context, and not for claims of duress, is that the former use of the theory helps a more sympathetic class of defendants than the latter.

\section{Traditional Law of Duress}

Compared to self-defense, duress is considered to operate more as an excuse than as a justification. ${ }^{168}$ However, the defense of duress

166. See, e.g., United States v. Marenghi, 893 F. Supp. 85, $94-97$ (D. Me. 1995) (observing the similarities between the elements of self-defense and duress, and declining to adopt a per se rule excluding expert testimony of battered woman syndrome in duress cases); State v. Williams, 937 P.2d 1052, 1058 (Wash. 1997) (en banc) (reversing battered woman's conviction for receiving public assistance overpayments because trial court should have given a duress instruction in light of the defendant's history of abuse); State v. Lambert, 312 S.E.2d 31, 34-35 (W. Va. 1984) (holding that history of violence was admissible to negate criminal intent in prosecution for fraud).

167. See United States v. Willis, 38 F.3d 170, 175-76 (5th Cir. 1994); Johnson, 956 F.2d at 900; Neelley v. State, 494 So. 2d 669, 689, 693 (Ala. Crim. App. 1985); State v. Mott, 931 P.2d 1046, 1054-55 (Ariz. 1997); Commonwealth v. Pike, 726 N.E.2d 940, 949-50 (Mass. 2000); State v. Copeland, 928 S.W.2d 828, 838 (Mo. 1996); State v. Sonko, 1996 Ohio App. LEXIS 2010, at *9 (Ohio Ct. App. May 22, 1996); State v. Lundgren, No. 90-L-15-125, 1994 WL 171657, at *18-19 (Ohio Ct. App. April 22, 1994); State v. Riker, 869 P.2d 43, 49 (Wash. 1994).

168. Some have treated duress as a justification, viewing it as a subspecies or variant of the necessity defense. For example, LaFave's view is that the traditional necessity and duress defenses can be treated together as a broader necessity or choice-of-evils defense, because both involve a claim that the defendant engaged in the conduct because of pressure exerted upon the defendant's mind and not upon the body. LAFAVE, supra note 4, at 476-77 (treating duress as a subspecies of the necessity defense); see United States v. Bailey, 444 U.S. 394, 410 (1980) ("Modern cases have tended to blur the distinction between duress and necessity."). Under this view, the only distinction between the defenses is the source of the pressure. In a necessity claim, the pressure has a natural source (such as a flood or fire), and in a duress claim, the source is a human actor. LAFAVE, supra note 4, at 476-77. This view does not recognize another, more critical difference between the two defense theories. Whereas necessity justifies only when the actor commits a crime that causes less harm than the evil that was avoided, see MODEL PENAL CODE \$ 3.02(1)(a) (1985), not every excused act of duress passes a strict utilitymaximizing test. "In conformity with this analysis, most scholars, courts, and state criminal codes that draw distinctions between justifications and excuses treat duress as an excuse defense." DRESSLER, supra note 4, at 300. 
shares a foundational premise with self-defense, reflecting a basic belief that an individual should not be punished for acts motivated by a desire for self-protection. Moreover, like self-defense, the defense of duress envisions an actor who maintains his capacity for rational decision making, unlike the excused insane actor or excused actor with a diminished mental capacity. ${ }^{169}$ The defendant who acts under duress retains his capacity for rational decision making but is placed by circumstance in a moral dilemma in which he lacks what can be characterized as a fair opportunity to avoid behaving unlawfully. As Professor Kadish has stated, "It is not, then, that there is literally no choice in these cases, but that there is no effective choice given the limits of moral fortitude, not just of the defendant, but of humankind generally. In other words, the choice exhibits no defect of character meriting blame." 170

Although jurisdictions vary in their doctrinal approach to the duress defense, ${ }^{171}$ George Fletcher observes correctly that "[t]he proverbial mode of duress is a gun pointed at the head as the ultimate persuader to do (or not do) something ... and right now!" 172 The Model Penal Code inquiry, for example, is whether the defendant's conduct was coerced by a threat of unlawful force that a "person of

169. Some courts have suggested otherwise by concluding that an actor who commits crimes under duress is excused because his acts are involuntary. See United States v. Bailey, 585 F.2d 1087, 1119-20 (D.C. Cir. 1978) (Wilkey, J., dissenting) ("[I]f legally sufficient duress exists, then the defendant may be acting involuntarily; if legally sufficient duress does not exist, then the defendant is deemed to be acting voluntarily as a matter of law."), rev'd, 444 U.S. 394 (1980); The Queen v. Hudson, [1971] 2 Q.B. 202, 206 (Eng. C.A.). However, this depiction of coerced acts as involuntary is not consistent with "voluntarism" as traditionally used in criminal law. The coerced crime is not, for example, the result of an involuntary seizure or muscle spasm. $C f$. People v. Grant, 360 N.E.2d 809, 814 (Ill. App. Ct. 1977) (reversing defendant's assault conviction because jury instructions did not accurately reflect the requirement of a voluntary act, where defendant claimed that his assaultive conduct was automatism triggered by a epilepsy). In a duress case, the defendant willfully moves his body to commit a crime. Consequently, as Dressler has noted, "[t]he coerced actor has the capacity to choose, i.e., she is not an automaton controlled by the coercing party." DRESSLER, supra note 4, at 302 .

170. Sanford H. Kadish, Excusing Crime, 75 CAL. L. REv. 257, 273-74 (1987); see also 4 WILLIAM BLACKSTONE, COMMENTARIES *30 (describing duress as "threats and menaces which induce a fear of death or other bodily harm, and which take away for that reason the guilt of many crimes and misdemeanours"); Joshua Dressler, Exegesis of the Law of Duress: Justifying the Excuse and Searching for its Limits, 62 S. CAL. L. REV. 1331,1365 (1989) ("Duress excuses when the available choices are not only hard but also unfair. A person acting under duress is excused, although he possessed the capacity to make the right choice ... if he lacked a fair opportunity to avoid acting unlawfully.").

171. See Dore, supra note 165, at Appendix for a thorough review of jurisdictional differences in the duress defense.

172. George P. Fletcher, Basic Concepts of Legal Thought 105 (1996) (omission in original). 
reasonable firmness" in his situation would have been unable to resist. ${ }^{173}$

A three-prong test for duress is a common approach, ${ }^{174}$ and each of the three prongs has an analog in the self-defense context. ${ }^{175}$ First, the defendant who claims duress must have acted in response to an immediate threat of death or serious bodily injury. ${ }^{176}$ This requirement is comparable to the requirement of immediacy or imminence present in the self-defense context. Second, the defendant must have had a "well-grounded" fear that the threat would have been carried out had she not committed the criminal act. ${ }^{177}$ By requiring that the defendant's fear be "well-grounded," the duress defense includes the objective test traditionally employed for selfdefense claims, asking what the impact of the threat would have been on the reasonable person. The final prong of the duress defense requires that the defendant must have had no reasonable opportunity to escape the threatened harm. ${ }^{178}$ This last requirement parallels the requirement that some jurisdictions impose in the self-defense context, requiring that the use of physical force be a last resort.

\section{Extension of Battered Woman Syndrome to Duress Claims}

Because the defenses of duress and self-defense share the same material elements, the same arguments to support the theory's use in self-defense cases support the theory's application to a defense of duress. Just as Walker's battered woman syndrome theory purports to explain why women who kill their batterers reasonably fear imminent harm, even during non-confrontational moments, ${ }^{179}$ the theory would explain why a battered woman has a "well-grounded" fear of "immediate" harm if she does not commit a crime with her batterer, even if her batterer did not literally hold a gun to her head

173. MOdel Penal CODE $§ 209(1)$ (1985).

174. For general discussions of the defense of duress, see DRESSLER, supra note 4 , at 297-99; LAFAVE, supra note 4, 467-76; 2 PAUL H. ROBINSON, CRIMINAL LAW DEFENSES $\$ 177$, at 347-72 (1984); and WILLIAMS, supra note 82, at 624-36.

175. See Faigman \& Wright, supra note 104, at 92 (noting that the elements of the duress defense bear a "close resemblance" to the elements of self-defense).

176. United States v. Toney, 27 F.3d 1245, 1248 (7th Cir. 1994); United States v. Homick, 964 F.2d 899, 905 (9th Cir. 1992); United States v. Santos, 932 F.2d 244, 249 (3d Cir. 1991); United States v. Scott, 901 F.2d 871, 873 (10th Cir. 1990); Dore, supra note 165, at 698 ; Faigman \& Wright, supra note 104, at 92.

177. See supra note 176.

178. United States v. Bailey, 444 U.S. 394, 410 (1980) (noting that, whatever the precise contours of the defense of duress, the defense will fail "if there was a reasonable, legal alternative to violating the law"); see also supra note 176 (collecting cases).

179. See supra notes $86-89$. 
during the commission of the offense. According to the battered woman syndrome theory, the domestic violence victim's familiarity with her batterer's cycle of violence may have led to a reasonable belief that harm was imminent if she protested his criminal behavior. ${ }^{180}$ Moreover, as a result of the cyclical nature of her batterer's violence and her lack of control over the abuse, she may perpetually fear immediate harm.

The battered woman syndrome theory also relates to the third prong of the duress defense, requiring that the defendant have no reasonable opportunity to escape the danger without committing the crime. Walker's version of learned helplessness depicts the battered woman as lacking the cognitive capacity to recognize options for escaping the batterer's abuse. ${ }^{181}$ Accordingly, one would expect the battered woman to remain with her batterer, even if he was a criminal who required her to help him. Additionally, Walker's battered woman prioritizes survival skills, ${ }^{182}$ so one would expect her to obey any command delivered by her batterer in an attempt-albeit perhaps futile-to avoid further episodes of violence.

Because duress and self-defense share the same elements of reasonableness, imminence, and a need for self-protection, one would expect the battered woman syndrome theory to be as relevant to one defense as to the other. In fact, Walker's theory appears even more applicable to the defense of duress than to self-defense. A primary discrepancy between the law of self-defense and Walker's battered woman syndrome theory is the difficulty explaining how a woman in a constant and heightened fear of danger, who is so helpless that she fails even to appreciate valid escape options, suddenly develops the impulse not just to stop or escape her batterer's abuse, but to end it permanently. ${ }^{183}$ In contrast, Walker's theory of learned helplessness, if true, does explain why an abused woman complies with her batterer's requests, even if she apparently has an opportunity to escape him, and even if compliance requires her to commit crimes against third parties. One would expect from Seligman's dog experiments that an abused woman would remain passive and obedient to her abuser, not decide on her own to kill him.

Despite the close nexus between the battered woman syndrome theory and the elements of the duress defense, there is less

180. See supra notes $86-89$.

181. WALKER (1979), supra note 21, at 49-50.

182. WALKER (1984), supra note 29 , at $33,87-89$.

183. See supra notes $149-53$. 
acceptance of the syndrome's relevance to a claim of duress than to a self-defense claim. ${ }^{184}$ Although some courts have extended the battered woman syndrome theory into the duress context ${ }^{185}$ it is not uncommon for courts faced with the issue of battered woman syndrome in the duress context to reject syndrome-based arguments that are accepted in the self-defense context; and instead to embrace traditional positions that are generally rejected in the self-defense context. ${ }^{186}$ Some courts have simply concluded with little analysis that the usefulness of battered woman syndrome evidence is limited to self-defense claims.

Consider, for example, the death sentence imposed upon Judith Ann Neelley, who was charged with capital murder after participating in a bizarre scheme to lure young girls for her husband, Alvin. ${ }^{187}$ Neelley's capital offense began when she lured thirteen-year-old Lisa Ann Millican from a mall, drove her to a motel, and tried to persuade her to have sex with Alvin. ${ }^{188}$ When Millican refused, Alvin overcame her resistance by telling her that Judith would kill her if she did not

184. See Faigman \& Wright, supra note 104 , at 92 (noting that "courts that have considered the [battered woman] syndrome in duress cases vary in their receptivity to this evidence").

185. See United States v. Marenghi, 893 F. Supp. 85, $94-97$ (D. Me. 1995); State v. Williams, 937 P.2d 1052, 1058 (Wash. 1997) (en banc); State v. Lambert, 312 S.E.2d 31, 35 (W. Va. 1984).

186. At least one federal circuit treats evidence of battered woman syndrome or domestic violence generally as a factor warranting a downward departure for coercion or duress under section $5 \mathrm{~K} 2.12$ of the Sentencing Guidelines. U.S.S.G., supra note 165 , $\S 5 \mathrm{~K} 2.12$; see, e.g., United States v. Weischedel, 201 F.3d 1250, 1255 (9th Cir. 2000) (allowing testimony regarding battered woman syndrome in determining defendant's sentence for murder); United States v. Ramos-Oseguera, 120 F.3d 1028, 1041 (9th Cir. 1997) (remanding in part so the district court could include evidence of battered woman syndrome, among other factors, in establishing a sentence); United States v. Johnson, 956 F.2d 894, 899-900 (9th Cir. 1992) (holding that battered woman syndrome could be considered in determining a sentence for a drug offense). In this Article, I am more interested with the use of such evidence toward a substantive defense, rather than in mitigation at sentencing.

187. According to the defense, the purpose of the Neelley's scheme was to satisfy Alvin's desire for girls with "small sex organs." State v. Neelley, 494 So. 2d 669, 676 (Ala. Crim. App. 1985), aff'd, 494 So. 2d 697 (Ala. 1986). For several days, Judith and Alvin cruised the streets of Rome, Georgia in separate automobiles looking for suitable victims. Id. at 690 . Alvin would alert Judith by C.B. radio when he saw a girl who suited him, and Judith would offer a ride to the targeted victim. Id. After days of rejections from numerous girls, Judith successfully lured thirteen-year-old Lisa Ann Millican from a mall into her car. Id.

188. Id. Judith Neelley was convicted of murdering Millican, but, in the course of her conduct, she abducted and killed another young woman, shot the woman's boyfriend and left him for dead, and attempted to abduct two other children from shopping malls. Id. at 691. Neelley also committed acts of robbery, firebombing, and forgery. Id. at 676. 
submit. ${ }^{189}$ The next day, ${ }^{190}$ Judith and Alvin, traveling in separate cars, took Millican to Alabama, where they extended their horrendous physical and sexual abuse of Millican for two more days. ${ }^{191}$

After three days of holding Millican captive, Judith drove Millican to a remote area and killed her. She initially tried to kill Millican by injecting her repeatedly in various parts of her body with liquid drain cleaner. ${ }^{192}$ After six failed injections, Judith marched Millican to the rim of the canyon and shot her in the back, ignoring Millican's pleas for her life and promises not to tell what had happened. ${ }^{193}$

At her trial on charges of capital murder, Judith admitted the alleged conduct, but asserted a defense that mixed elements of duress and coercion with evidence that Judith was a battered woman. ${ }^{194}$ The jury considered the details of Judith's deprived childhood, including the fact that she ran away from home at the age of fifteen to marry Alvin, a twenty-six-year-old ex-convict. ${ }^{195}$ According to Judith, Alvin subjected her to repeated psychological, physical, and sexual abuse during the course of their relationship, training her to do everything she could to satisfy Alvin and avoid his beatings. ${ }^{196}$

\footnotetext{
189. Id. at 690 . ld.

190. The Neelleys kept Millican handcuffed overnight to prevent her from escaping.

191. Shortly after their arrival in Alabama, Judith hit Millican in the head several times with a slapjack in an attempt to render her unconscious. Id. After Judith's attempts failed, Alvin raped Millican again, then left her to sleep overnight on the floor, unclothed and handcuffed to the bed. Id. The following day, while Judith was present, Alvin raped Millican twice more. Id.

192. Id. Judith took Millican to a canyon and handcuffed her facedown to a tree. Id. Judith told Millican that she was going to give her a shot that would make her sleep and that she would be free to go once she woke. Id. Judith then injected Lisa in the neck with liquid drain cleaner. Id. When Lisa did not die in five minutes, Judith injected her again five more times in her neck, arms, and buttocks, waiting five minutes between each injection to see if, this time, Millican would succumb. Id.

193. Id. at 691 . When Lisa fell backward instead of falling into the canyon as planned, Judith picked up the body and propelled it into the canyon. Id.

194. Although the defense did not refer explicitly to "battered woman syndrome," defense attorneys did present evidence relating to learned helplessness and the related "Stockholm syndrome." See Neelley v. State, 642 So. 2d 494, 506 (Ala. Crim. App. 1993). "Stockholm syndrome" refers to the phenomenon in which hostages bond with their kidnappers. Hope Toffel, Note, Crazy Women, Unharmed Men, and Evil Children: Confronting the Myths About Battered People Who Kill Their Abusers, and the Argument for Extending Battering Syndrome Self-Defenses to all Victims of Domestic Violence, $70 \mathrm{~S}$. CAL. L. ReV. 337, 353 (1996). The theory has been offered to explain why battered women stay with their abusers. See id. at 351-55.
}

195. Neelley, 494 So. $2 d$ at 676.

196. Neelley not only admitted to the facts surrounding the murder of Lisa Millican, 
The jury convicted Judith Neelley of murder, but ten jurors in the sentencing phase recommended life without parole and only two recommended a sentence of death. ${ }^{197}$ Nevertheless, the trial judge rejected the jury's recommendation and sentenced Neelley to die by electrocution. ${ }^{198}$ As the court articulated its reasoning, "There were numerous opportunities for the defendant to break with her husband and seek help had she felt the need or been so inclined. These opportunities were enhanced by the fact that the defendant was armed and traveling in a separate vehicle during most of their exploits." 199 Moreover, the judge stated explicitly that, while battered woman syndrome might provide a justifiable extension of the selfdefense doctrine, it was inapplicable where a battered woman chose to engage in criminal behavior against innocent third persons:

In a growing number of cases, the law has recognized the battered woman syndrome in judging the culpability of women who kill their batterers. Such recognition is entirely consistent with the legal concepts of self-defense and selfprotection. A major distinguishing fact, however, between these cases and the one before the court is that the petitioner did not choose to kill her batterer. She chose, instead, to kill an innocent third party, a choice which falls outside any acceptable notion of self-protection. The battered woman syndrome offers no plausible explanation for that choice, and the court is unconvinced that the battered woman syndrome provides any reason for mitigating petitioner's sentence. ${ }^{200}$

but also volunteered additional information about her criminal activities with Alvin, including shocking accounts of attempted murder, burglary, forgery, arson, theft, child abuse, incest, rape, and sexual sadism. Id.

197. Id. at 671 .

198. Id.

199. Sentencing Order, State v. Neelley, Circuit Court of DeKalb County, included as Appendix III in Neelley, 494 So. 2d at 689, 693; see also Commonwealth v. Pike, 726 N.E.2d 940, 949 (Mass. 2000) (affirming trial court's findings that defendant's post-trial testimony was not credible, because once she was separated from her batterer, defendant would not have continued to feel controlled by him and continue to conceal the abuse).

200. Neelley, 642 So. $2 \mathrm{~d}$ at 508 . The court correctly noted that many jurisdictions, including its own, adopt a per se rule against permitting duress as a defense to homicide. This exception to duress provides a legitimate basis for denying a defense to a battered woman who kills under the coercion of her batterer, while providing one to a battered woman who kills her abuser. However, the limitation upon the ability to use lethal force under duress does not provide a basis for treating the battered woman syndrome theory as wholly irrelevant when a battered woman commits crimes with her abuser. For example, despite the homicide exception to duress, the court in Neelley certainly could have considered the theory as a basis for mitigation at sentencing. See also State v. Riker, 869 P.2d 43, 49 (Wash. 1994) (using Frye to reject evidence regarding the battered woman 
Other courts have at least attempted to articulate a basis for refusing to apply evidence of the battered woman syndrome in the duress context by reasoning that the syndrome describes the subjective beliefs of the defendant and is therefore irrelevant to the issue of whether the objective tests under the duress defense have been met. ${ }^{201}$ For example, under the Model Penal Code, duress is established only if a person of "ordinary firmness" would succumb to the threat. ${ }^{202}$ Similarly, there must be no reasonable legal alternative to violating the law. ${ }^{203}$ Because these standards establish an objective inquiry, the argument goes, the consideration of battered woman syndrome evidence in applying the standards would turn the objective inquiry that duress has always required into a subjective one that focuses instead on whether the individual defendant's unique psychological condition prevented her from resisting coercion. ${ }^{204}$

This reliance upon the distinction between objective and subjective standards, although analytically sound in the duress context, fails to explain why the battered woman syndrome theory is any more acceptable in the self-defense context. Like the standard for duress, the traditional approach to self-defense also requires an objective standard, asking whether a reasonable person would have perceived a threat. ${ }^{205}$ Accordingly, an advocate of the objectivesubjective distinction as a basis for rejecting battered woman syndrome evidence in the duress context should conclude, as I do, ${ }^{206}$ that the evidence is equally inapplicable to an objective standard of self-defense. Nevertheless, when a battered woman kills her batterer and claims self-defense, courts have permitted evidence of the battered woman syndrome not only to support the defendant's

syndrome outside of the self-defense context, because the court was "unable to conclude that this extension of battered person principles has achieved general acceptance in the appropriate scientific community"). Similarly, the rule against permitting duress as a defense to homicide does not preclude application of the defense to battered women who are accused of committing crimes other than homicide with their batterers. See, e.g., United States v. Willis, 38 F.3d 170, 174-77 (5th Cir. 1994) (holding that evidence of the battered woman's syndrome was not relevant to determining whether defendant accused of carrying a firearm during a drug trafficking crime acted under duress).

201. Willis, 38 F.3d at 174-77; United States v. Johnson, 956 F.2d 894, 898 (9th Cir. 1992).

202. Model Penal CODE $\S 2.09$ (1985); see Willis, 38 F.3d at 176.

203. See United States v. Bailey, 444 U.S. 394, 410 (1980); Willis, 38 F.3d at 176.

204. See Willis, 38 F.3d at 176.

205. See LAFAVE, supra note 4, at 493-95.

206. See infra Sections II.B \& III.D. 
subjective perception of her situation, but also to determine the objective reasonableness of her perception and response. ${ }^{207}$

With no convincing basis upon which to admit battered woman syndrome evidence in the self-defense context and yet exclude it in the duress context, courts that draw this distinction ultimately appear satisfied with the unexplained, policy-based conclusion that the extension of such evidence to the duress context would be "unwise." "208

In addition to the lack of consensus among courts regarding the application of battered woman syndrome in the duress context, there are other indications that the criminal justice system treats battered women who claim duress differently than battered women who kill their abusers. Although some trial courts have chosen as a matter of discretion to permit battered women to claim duress and present evidence of the battered woman syndrome to support their claims, ${ }^{209}$ appellate courts have been reluctant to reverse convictions based on a

207. See People v. Humphrey, 921 P.2d 1, 10 (Cal. 1996) (holding that the trial court erred by instructing jury that evidence of the battered woman syndrome was admissible only regarding the subjective, and not the objective, prong of the self-defense standard).

208. See Willis, 38 F.3d at 176. Other courts, rather than make their own policy-based decision to permit the evidence in self-defense cases but not duress cases, have reached the same result by relying on the legislature's perceived intentions to do so, without making an independent inquiry regarding the admissibility of the evidence absent support from a specific statute. See, e.g., State v. Copeland, 928 S.W.2d 828, 838 (Mo. 1996) (en banc) ("Had the legislature intended battered spouse syndrome to be a general defense, it could easily have made provision for that defense. If self-defense is not in the case, there is no authority for admitting such evidence unless in support of a claim of mental disease or defect."); State v. Sonko, No. 95CA006181, 1996 Ohio App. LEXIS 2010, at *9 (Ohio Ct. App. May 22, 1996) (relying on statutory limitation to affirm conviction of woman who sought to use evidence of the battered woman syndrome to excuse her participation in drug distribution); State v. Lundgren, No. 90-L-15-125, 1994 WL 171657, at *18-19 (Ohio Ct. App. Apr. 22, 1994) (relying upon statutory limitation to exclude evidence of the battered woman syndrome theory offered by battered woman against murder charges arising from bizarre religious sacrifice of a family); Campbell v. State, 999 P.2d 649, 660 (Wyo. 2000) (holding that statute regarding battered woman syndrome "expressly limits its reach to the affirmative defense of self-defense" and therefore did not apply to assist duress defense against charges of child endangerment).

209. See, e.g., United States v. Simpson, 979 F.2d 1282, 1288 (8th Cir. 1992) (finding sufficient evidence to support bank robbery conviction of battered woman who claimed coercion as a defense, where defendant was alone in getaway car during the scoping and robbing of bank, and was aware of nearby police station); United States v. Santos, 932 F.2d 244, 249 (3d Cir. 1991) (affirming legality of trial court's sentence of battered woman who presented duress defense); People v. Smith, 608 N.E.2d 1259, 1261-70 (Ill. App. Ct. 1993) (finding that a sixty year sentence was not an abuse of trial court's discretion when battered woman joined husband in killing their three-month-old son by pouring a caustic substance down his throat); State v. Bockorny, 863 P.2d 1296, 1300 (Or. Ct. App. 1993) (affirming conviction of battered woman who helped husband rape, stab, and strangle another woman). 
trial court's refusal to do so. ${ }^{210}$ Moreover, one of the only appellate court decisions in which a battered woman's conviction was reversed because she was denied an adequate opportunity to present her duress defense ${ }^{211}$ was subsequently limited to specific intent crimes. ${ }^{212}$ In contrast, appellate courts often find reversible error in a trial court's refusal to permit domestic violence victims who kill their

210. See, e.g., United States v. Madoch, 149 F.3d 596, 599 (7th Cir. 1998) (declining to "expand the law relating to battered women's syndrome" in a duress case because of insufficient development of the record below); United States v. Thomas, 11 F.3d 1392, 1399 (7th Cir. 1993) (affirming trial court's exclusion of evidence regarding battered woman syndrome because defendant did not file required notice of intent to present defense based on mental state); United States v. Archer, No. 91-50743, 1993 U.S. App. LEXIS 24875, at *5-6 (9th Cir. Sept. 23, 1993) (same); United States v. Homick, 964 F.2d 899, 905-06 (9th Cir. 1992) (affirming trial court's refusal to give a duress instruction, because no reasonable jury could apply the defense when battered woman conspired with her ex-husband while he was in another state and where the monitored conversations between defendant and batterer were not threatening); United States v. Sebresos, No. 9110193, 1992 U.S. App. LEXIS 17757, at *6-7 (9th Cir. July 22, 1992) (upholding exclusion of battered woman syndrome evidence to support defense of duress to charge of embezzlement); United States v. Sixty Acres in Etowah County, 930 F.2d 857, 860-61 (11th Cir. 1991) (reversing dismissal of complaint seeking seizure of battered woman's property, because there was no imminent threat against the woman to prevent her from reporting her husband's criminal activities, and a generalized fear of future harm from her husband was insufficient to support duress defense); United States v. 38011 Moravian, No. 89-CV-73098-DT, 1991 U.S. Dist. LEXIS 14358, at *4-5 (E.D. Mich. June 19, 1991) (rejecting battered woman's claim in forfeiture action that she did not consent to her husband's criminal activity, where there was only generalized fear and no threat of immediate harm); Cox v. State, 843 S.W.2d 750, 755 (Tex. Crim. App. 1992) (affirming trial court's exclusion of evidence regarding battered woman syndrome as irrelevant); State v. Wyatt, 482 S.E.2d 147, 158 (W. Va. 1996) (reversing conviction on other grounds, but noting that it was not reversible error to preclude expert from testifying about battered woman's syndrome in a case against battered woman for child abuse and neglect).

211. See Dunn v. Roberts, 963 F.2d 308, 313-314 (10th Cir. 1992) (reversing conviction because defendant was denied funding for psychiatric expert to buttress duress claim). In Dunn, the defendant was convicted of aiding and abetting a crime spree that included felony murder, kidnapping, and aggravated robbery. Id. 309-10. Unlike many of the cases in the duress area, there was no direct evidence in Dunn that the defendant was an actual participant in the crimes. See id. at 311 (noting that the only evidence of any participation by the defendant was the testimony of one witness who said he saw someone who looked like Dunn driving the truck used by the primary defendant). She was convicted solely on her presence during the spree. Id. The Tenth Circuit held that, under those circumstances, evidence of battered woman syndrome was necessary to provide an alternative explanation for the defendant's presence with her batterer. Id. at 311-13; cf. United States v. Ramos-Oseguera, 120 F.3d 1028, 1038 (9th Cir. 1997) (holding that because one paragraph of defendant's proposed jury instruction was inaccurate, appellate court will not decide whether it would have been error to exclude legally accurate instructions that did what defendant's offered instructions purported to do: put the duress defense in context with evidence of a battering relationship), overruled on other grounds by United States v. Nordby, 225 F.3d 1053 (9th Cir. 2000).

212. United States v. Willis, 38 F.3d 170, 177 n.7 (5th Cir. 1994). 
batterers to claim self-defense or present expert testimony regarding battered woman syndrome. ${ }^{213}$

In addition to the clear split of authority regarding the admissibility of battered women syndrome evidence in the duress context, there are other indicators suggesting at least an implicit discomfort with such evidence when offered to support a duress claim. For example, a number of states have taken the unusual step of removing from the court's hands the determination of whether expert testimony of battered woman syndrome is admissible, and mandate by statute that the evidence meets the standards of admissibility as a matter of law. ${ }^{214}$ However, many of these statutes are explicitly limited-apparently for political reasons-to cases in which the evidence is offered to support a claim of self-defense. ${ }^{215}$

213. See, e.g., Rogers v. State, 616 So. 2d 1098, 1100 (Fla. Dist. Ct. App. 1993) (reversing conviction because trial court erroneously excluded testimony explaining battered woman syndrome), overruled in part by State v. Rogers, 630 So. 2d 177 (Fla. 1993); People v. Evans, 631 N.E.2d 281, 295 (Ill. App. Ct. 1994) (reversing conviction because state had not disproved self-defense by a reasonable doubt); State v. Williams, 787 S.W.2d 308, 313 (Mo. Ct. App. 1990) (reversing conviction where defendant's counsel had failed to present evidence of battered woman syndrome); State v. Koss, 551 N.E.2d 970, 970 (Ohio 1990) (reversing conviction because trial court erroneously excluded expert testimony regarding battered woman syndrome); State v. Zimmerman, 823 S.W.2d 220, 227 (Tenn. Crim. App. 1991) (same); State v. Allery, 682 P.2d 312, 316 (Wash. 1984) (en banc) (same).

214. See supra note 158. California's legislature went even further, enacting a subjectspecific habeas corpus provision that applies to defendants convicted prior to the enactment of Section 1107 of the California Evidence Code, which governs the admissibility of battered women's syndrome evidence. Act of Sept. 13, 2001, 2001 Cal. Stat. ch. 858, $\$ 1$ (codified at CAL. PENAL CODE $\$ 1473.5$ (West Supp. 2002)). Under the new law, a writ of habeas corpus may be granted if evidence relating to the syndrome was not introduced at trial, and if there is a reasonable probability that the results of the trial would have been different if the evidence had been admitted. CAL. PENAL CODE $\S 1473.5$ (West Supp. 2002). The first release pursuant to the new law was awarded to Marva Wallace two weeks after California's governor denied Wallace parole. Anna Gorman, Wife Who Killed Husband Free After 17 Years, L.A. Times, Oct. 26, 2002, at A1 (reporting Wallace's release).

215. See Ohio Rev. Code AnN. $\$ 2901.06$ (Anderson 1999); Mo. Rev. Stat. $\S 563.033(1)$ (Supp. 1994); WYO. STAT. ANN. § 6-1-203(b) (Michie 2001). But see MASS. ANN. LAwS ch. 233, $\S 23 \mathrm{~F}$ (Law Co-op. 2000) (stating that evidence of battered woman syndrome may be the subject of expert testimony at the trial of criminal cases "charging the use of force against another where the issue of defense of self or another, defense of duress or coercion, or accidental harm is asserted"). Courts have relied upon the limited scope of these syndrome-specific evidentiary rules as a basis for refusing to admit expert testimony regarding the syndrome in support of a claim of duress. E.g., State v. Copeland, 928 S.W.2d 828, 838 (Mo. 1996) ("Had the legislature intended battered spouse syndrome to be a general defense, it could easily have made provision for that defense. If selfdefense is not in the case, there is no authority for admitting such evidence unless in support of a claim of mental disease or defect."); State v. Sonko, No. 95CA006181, 1996 Ohio App. LEXIS 2010, at *9 (Ohio Ct. App. May 22, 1996) (relying on statutory 
Commentators also appear to embrace the theory of battered woman syndrome more readily when a woman kills her abuser than when she commits offenses in cooperation with him. Commentary on battered woman syndrome in women who kill their batterers has been vast, ${ }^{216}$ with many commentators eager to advocate the use of the syndrome as an extension of the traditional self-defense claim. ${ }^{217}$ Fewer commentators, however, even mention battered women who harm innocent third parties, ${ }^{218}$ and those who do appear to concede

limitation to affirm conviction of woman who sought to use evidence of the battered woman syndrome to excuse her participation in drug distribution); Campbell v. State, 999 P.2d 649, 660 (Wyo. 2000) (finding that Campbell could not raise the defense of coercion even though the abuse she suffered caused her to believe that she was in imminent danger of death if she did not endanger her child's life by delaying medical care).

216. See generally CyNTHIA Gillespie, Justifiable Homicide: BATTERED WOMEN, Self-DefENSE, AND THE LAW (1989) (discussing the battered woman syndrome from historical, social, and legal perspectives with an extensive list of books, articles, and cases on this subject contained in the appendix); WALKER (1979), supra note 21 (setting out the original statement of the battered woman syndrome); Erich D. Andersen \& Anne Read-Andersen, Constitutional Dimensions of the Battered Woman Syndrome, 53 OHIO ST. L.J. 363 (1992) (examining the "constitutional dimensions of the battered woman syndrome"); Michael A. Buda \& Teresa L. Butler, The Battered Wife Syndrome: A Back Door Assault On Domestic Violence, 23 J. FAM. L. 359 (1984) discussing the criminal justice system's inadequacies in addressing domestic violence and murder); Phyllis Crocker, The Meaning of Equality for Battered Women Who Kill Men in Self-Defense, 8 HARV. WOMEN's L.J. 121, 130-31 (1985) (suggesting trial strategies based on feminist theory that could be applied in the case of a battered woman); Rosen, supra note 5 (arguing for a self-defense standard for battered women based on necessity without an imminence requirement); Rocco C. Cipparone, Jr., Comment, The Defense Of Battered Women Who Kill, 135 U. PA. L. REv. 427 (1987) (advocating use of insanity defense); Loraine P. Eber, Note, The Battered Wife's Dilemma: To Kill Or To Be Killed, 32 HASTINGS L. J. 895 (1981) (concluding that perceptions derived from sexual discrimination must be evaluated in determining the reasonableness of the battered woman's conduct); Jeffrey Robinson, Note, Defense Strategies For Battered Women Who Assault Their Mates: State v. Curry, 4 HARv. WOMEN's L.J. 161 (1981) (examining the possible uses of battered woman syndrome to support a self-defense claim).

217. See, e.g., Faigman \& Wright, supra note 104, at 75 n.52 (citing a "representative sample" of the "substantial numbers of legal commentators [who] have rallied around the use of syndrome evidence"). But see Acker \& Toch, supra note 155, at 142-43 (arguing that expert testimony about battered woman syndrome has the potential to divert attention from facts that are logically related to a self-defense claim); Faigman, supra note 26, at 643-47 (arguing that courts should not admit expert testimony based on battered woman syndrome research in self-defense cases); Marilyn Hall Mitchell, Note, Does Wife Abuse Justify Homicide?, 24 WAYNE L. REV. 1705 (1978) (asserting that a battered woman defense "would not only validate a kind of vigilante justice the law is supposed to preclude, but would also establish a virtual sex discrimination classification").

218. As one commentator has noted, "[w]hile a voluminous amount of scholarship concerns battered women's self-defense work ... scholars have paid relatively little attention to the potentially broader use of the battered woman syndrome to support a defense of duress." Dore, supra note 165, at 672, n.24. For additional discussion of the battered woman syndrome in the duress context, see generally Meredith Blake, Coerced Into Crime: The Application of Battered Woman Syndrome to the Defense of Duress, 9 
that the claims of these women are less sympathetic than those of women who kill their abusers. ${ }^{219}$

Finally, trends in executive clemency also suggest that a battered woman's decision to kill her abuser is more readily excused than her choice to participate in his criminal schemes. The explosion of executive clemency granted to domestic violence victims began in 1990, when, four days before Christmas, the governor of Ohio commuted the sentences of twenty-five battered women who had killed or assaulted their batterers. ${ }^{220}$ Within two months, the governor of Maryland granted clemency to eight, similarly convicted battered women.221 Illinois's governor followed suit by granting clemency in 1994, 1995, and 1997 to domestic violence victims who

WIS. WoMEn's L.J. 67 (1994); Beth I.Z. Boland, Battered Women Who Act Under Duress, 28 NEW ENG. L. REV. 603 (1994); Coughlin, supra note 149, at 56-59 (criticizing the application of the battered woman syndrome in duress cases as reminiscent of the old marital coercion doctrine, which presumed that women acted at the command of their husbands); Susan D. Appel, Note, Beyond Self-Defense: The Use of Battered Woman Syndrome in Duress Defenses, 1994 U. ILL. L. REV. 955, 977-980 (1994) (arguing that evidence of the battered woman syndrome theory should be admitted to support claims of duress by battered women); Christine Emerson, Note, United States v. Willis: No Room for the Battered Woman Syndrome in the Fifth Circuit?, 48 BAYLOR L. REV. 317 (1996); Monique Gousie, Comment, From Self-Defense to Coercion: McMaugh v. State-Use of Battered Woman's Syndrome to Defend Wife's Involvement in Third-Party Murder, 28 NEW ENG. L. REV. 453, 473-80 (1993) (advocating for the use of the battered woman syndrome theory to support claims of duress); Monacella, supra note 104 (arguing that evidence of the battered woman syndrome theory should be admitted to support claims of duress by battered women); and Ann-Marie Montgomery, Note, State v. Riker, Battered Women Under Duress: The Concept the Washington Supreme Court Could Not Grasp, 19 SEATTLE U. L. REV. 385 (1996) (same).

219. For example, one commentator states that, "[w]hile obviously those battered women who kill their batterers garner the most sympathy and can argue most persuasively the mitigated seriousness of their homicides, battered women who kill third-party, completely 'innocent' victims nonetheless have a unique partial explanation of their otherwise unfathomable acts." Streib, supra note 49, at 187 . He therefore argues that women who kill their batterers should enjoy explicit protection from the death penalty, while battered women who commit crimes in cooperation with their abusers should simply be given a mitigating factor arguing against imposition of the death penalty. Id. at 196 . Other commentators offer similar qualification of their support for the conduct of battered women who commit crimes with their batterers. E.g., Appel, supra note 218, at 979-80 (acknowledging that battered women who claim duress are not "innocent," but also are not culpable); Monacella, supra note 104, at 700 (advocating use of the battered woman syndrome theory to support duress claims, but stating that the evidence "in the context of duress should not be used to endorse the defendant's behavior or account for what happened").

220. Isabel Wilkerson, Clemency Granted to 25 Women Convicted for Assault or Murder, N.Y. TIMES, Dec. 22, 1990, at A1.

221. See Tamar Lewin, More States Study Clemency for Women Who Killed Abusers, N.Y. TIMES, Feb. 21, 1991, at A19. 
committed crimes against their batterers. ${ }^{222}$ The trend continues. In 2000, California Governor Gray Davis released a woman convicted of murdering her abusive boyfriend. ${ }^{223}$ Despite the proliferation of clemencies for battered women who kill their abusers, reports of clemency are rare for battered women convicted of committing a crime at her batterer's request, and I am not aware of any governor who has released such a defendant. ${ }^{224}$

222. Illinois Clemency Project for Battered Women, at http://pubweb.nwu.edu/ mva472/ clemency2.htm (last visited Nov. 9, 2002) (on file with the North Carolina Law Review); see Julie Irwin, Abuse Argument in Doubt at 12 Clemency Hearings, CHI. TRIB., Apr. 6, 1994, at N1; see also John Milne, Abuse as Defense Being Mulled, Boston GloBE, Mar. 6, 1994, at 43 (reporting that Massachusetts Governor Weld has slowly released the so-called "Framingham Eight," eight women who killed their abusers); see also Krause, supra note 31, at 699 (arguing that decision makers and advocates for battered women should look beyond clemency efforts, to the ultimate goal of preventing domestic violence). See generally Linda L. Ammons, Discretionary Justice: A Legal and Policy Analysis of a Governor's Use of the Clemency Power in the Cases of Incarcerated Battered Women, 3 J.L. \& POL'Y. 1 (1994) (arguing that "the clemency power exists because this strict or misapplication or inadequacy of the law can bring harsh, unfair, and unjust results"); Martin E. Veinsreideris, The Prospective Effects of Modifying Existing Law to Accommodate Preemptive Self-Defense by Battered Women, 149 U. PA. L. REV. 613, 64044 (2000) (advocating clemency for battered women who kill); Christine Noelle Becker, Comment, Clemency for Killers? Pardoning Battered Women Who Strike Back, 29 LOY. L.A. L. REv. 297 (1995) (concluding that battered women who have killed their abusers may be particularly suited for the principled exercise of executive clemency).

223. Killer's Parole Approved By California Governor, N.Y. TIMES, Sept. 25, 2000, at A25.

224. One researcher's recent survey reports only two cases in which capital sentences were commuted for battered women who killed in concert with their batterers, Judith Neelley and Debra Brown. See Elizabeth Rapaport, Staying Alive: Executive Clemency, Equal Protection, and the Politics of Gender in Women's Capital Cases, 4 BUFF. CRIM. L. REV. 967, 994 n.97 (2001). Neither woman was pardoned, so both remained in prison. See At End of Term, Ohio's Governor Commutes Death Sentence for 8, N.Y. TIMES, Jan. 12, 1991, at A12 (noting the commutation of the sentence of Debra Brown, who killed a 15year-old under the duress of a male companion who was also convicted of murder); supra note 198. Moreover, both commutations sparked heated controversies. Alabama Governor Fob James's commutation of Debra Brown's sentence, granted in the last days of the governor's term and with a refusal to comment, prompted a proposal to amend the state constitution to revoke the governor's power to commute capital sentences. See Mike Cason, Bill Would Remove Power to Commute, Montgomery Advertiser, Jan. 20, 1999, at 1A. Ohio Governor Richard Celeste's commutation of Debra Brown's sentence also occurred in the last days of the governor's term, as part of a group of eight commutations. At End of Term, Ohio's Governor Commutes Death Sentence for 8, supra. In justifying the pardon, Celeste cited not just the abuse inflicted by Brown's boyfriend, but also her mental retardation. $I d$. Four of the other seven defendants whose sentences were commuted at the same time were also retarded. Id. The Ohio Attorney General sued to set aside seven of the eight commutations. See State ex rel. Maurer v. Sheward, 644 N.E.2d 369, 379 (Ohio 1994) (upholding commutations). Citing the Governor's fulfillment of procedural requirements, the Attorney General did not seek to set aside one of the eight commutations, which was granted to a woman who hired a man to kill her abusive husband. Alan Johnson, Death Penalty Commutations in Court Today, Colum. 
In short, although battered women who claim duress have had some success relying upon the battered woman syndrome theory, ${ }^{225}$ they have enjoyed less success than battered women who claim selfdefense. It appears, in other words, that the battered woman syndrome theory enjoys wide acceptance when invoked in the selfdefense context to help a battered woman who has killed her batterer, but triggers at least reluctance when sought to be applied outside the battering relationship to excuse criminal conduct affecting innocent third parties. If we truly believed that the battered women syndrome accurately described the characteristics of domestic violence victims, the discrepancy between the acceptance of the syndrome in the selfdefense and duress contexts is unexplainable. One might argue that the reluctance to expand the defense of duress is attributable to the moral ambivalence already surrounding the traditional scope of the defense. Because the duress doctrine excuses crimes committed against innocent third parties, it may simply be a less favored defense generally than self-defense. For example, the common law rule that duress could never excuse an intentional homicide certainly reflects a preference for defensive force over coerced force. ${ }^{226}$ However, the preferential treatment of the justification of self-defense over the excuse of duress explains only the ultimate result in these cases, i.e., that battered women who kill in self-defense are shown more sympathy and are more likely to get requested jury instructions, be acquitted, or successfully appeal their convictions than battered women who act under duress against third parties. This preference does not explain the differential acceptance of the theory of battered

DisPaTCH, Jan. 28, 1992, at 3C, LEXIS, Colum. Dispatch File. Nor did he seek to set aside the Governor's grant of clemency just three weeks earlier to twenty-five women who claimed that they defended themselves against their batterers. See At End of Term, Ohio's Governor Commutes Death Sentence for 8, supra. In sum, there are rare instances of executive clemency for abused. women who commit crimes against third parties in cooperation with their batterers, but they are far less frequent, and apparently far more controversial, than grants of clemency to battered women who kill their batterers.

225. See United States v. Marenghi, 893 F. Supp. 85, 94-97 (D. Me. 1995); State v. Williams, 937 P.2d 1052, 1058 (Wash. 1997); State v. Lambert, 312 S.E.2d 31, 34-35 (W. Va. 1984).

226. The unavailability of duress as a defense to murder has been traced to "an unbroken tradition of authority dating back to Hale and Blackstone." The Queen v. Howe, [1987] A.C. 417, 427. The exception remains common today and is codified by statute in various states. See WASH. REV. CODE ANN. § 9.A.16.060(2) (West 2000) ("The defense of duress is not available if the crime charged is murder, manslaughter or homicide by abuse."); see also Hunt v. State, 753 So. 2d 609, 613 (Fla. Dist. Ct. App. 2000) (retaining the common law rule that duress is not a defense to an intentional homicide) (citing Wright v. State, 402 So. 2d 493, 498 (Fla. Dist. Ct. App. 1981)); Jackson v. State, 558 S.W.2d 816, 819-20 (Mo. Ct. App. 1997) (same). 
woman syndrome itself in the two contexts. As discussed above, the theory itself is a better fit with the defense of duress than with a claim of justified self-defense.

\section{AN ALTERNATIVE EXPLANATION FOR WHY BATTERED WOMEN STAY AND THE IMPLICATIONS UPON CRIMINAL DEFENSES}

In short, there is an incongruity between the empirical and analytical strength of the battered woman syndrome and the acceptance that the theory has enjoyed among social scientists and the legal system. Moreover, the doctrinally warranted extension of the self-defense cases involving battered women have largely been rejected. For example, courts do not apply psychologicallyindividualized reasonableness standards to other actors who claim self-defense, such as the "reasonable schizophrenic" or "reasonable delusional man."227 Similarly, the battered woman syndrome theory itself has enjoyed less support when applied to the defense of duress, even though the social science theory is more descriptive of the coerced battered woman than the defensive battered woman. ${ }^{228}$ From all appearances, then, the battered woman syndrome is a psychological and legal fiction that has been created to accommodate the self-defense claims of sympathetic domestic violence victims whose cases may not always meet traditional self-defense requirements. By characterizing women as impaired, syndrome advocates have attempted to explain what are perceived as "problems" to such claims: why women stay in abusive relationships and why some battered women may kill during non-confrontational moments.

These problems, however, can be explained without resorting to pathology. A woman's participation in an abusive relationship can be understood without depicting domestic violence victims as homogenous, irrational, and cognitively impaired. In light of individual factual circumstances that vary from woman to woman, a domestic violence victim's decision to remain in a battering relationship may not evidence cognitive incapacity. It may, in fact, demonstrate that the woman is a rational actor making a reasoned decision based upon an evaluation of her viable escape options and the value she assigns to competing priorities.

Viewing battered women as rational actors choosing among options that are limited by their factual circumstances has

227. See supra notes 134-41.

228. See supra Section II.C.2. 
ramifications for their self-defense and duress claims. The doctrinal impediment for battered women who used defensive force during non-confrontational moments has been the requirement of a reasonable fear of imminent harm. The prevailing approach uses the fiction of battered woman syndrome as a means to argue that domestic violence victims meet this requirement. An alternative approach, however, is to question directly the requirement of imminency and change the scope of self-defense to encompass justified uses of force.

This section sets forth an alternative approach to understanding the decisions of battered women who stay, by viewing battered women as rational actors. Using the rational actor approach, this Article then suggests an alternative analysis of battered women's claims of duress and self-defense.

\section{A. An Alternative Understanding of Battered Women}

The primary purpose of the battered woman syndrome theory is to explain why battered women do not leave their batterers. As an initial matter, the reality is that many battered women do leave the abusive relationship. One recent study, for example, found that more than a third of the married battered women studied left their husbands during the two years they were studied, when the divorce rate in the general population during a two-year period is typically from two to five percent. ${ }^{229}$ As Sarah Buel explains, "It is a myth that [battered women] do not leave. We generally leave many times before we are finally able to leave and stay away." ${ }^{230}$ Battered women are also not universally submissive. One research team concluded that battered women as a group were "resourceful, heroic, and consistently held their ground."231

To the extent that battered women may stay with their batterers in greater numbers and for longer periods than one might expect, the decisions of domestic violence victims to remain with their batterers can be understood without depicting women as syndromatic. Battered woman syndrome lacks solid empirical evidence supporting its validity, ${ }^{232}$ so there is little reason to believe that domestic violence

229. NeIL S. JACOBSON \& JOHN H. GOTTMAN, WHEN MEN BATTER WOMEN 49, 136 (1998) (reporting that thirty-eight percent of the battered women in the couples studied by the researchers left their husbands during a two-year period).

230. DEFENDING OUR LIVES (Cambridge University Films 1993) (citing statistics of the Federal Bureau of Investigations).

231. JACOBSON \& GOTTMAN, supra note 229, at 63 .

232. See supra Section II.A. 
victims share the specific psychological traits described by Walker. Moreover, there is little reason to believe that battered women all share any particular psychological infirmity that prevents rational decision making, no matter how one might describe it.

Walker's own interviews of domestic violence victims indicate that they do not literally lack the cognitive capacity to appreciate their escape options; rather, the unfortunate reality is that what victims lack are viable escape options. ${ }^{233}$ Moreover, sociological evidence demonstrates that there is no single explanation for the continuation of battering relationships. Battered women remain in abusive relationships for a myriad of diverse reasons that are specific to the actor. Considering her own unique situation and the value she assigns to competing priorities, a woman may make a rational decision to stay in a domestic relationship, even after one or many instances of physical abuse.

A woman's current presence in such a relationship does not mean that she wants to stay. Many women stay because they justifiably fear that leaving would be even more dangerous. ${ }^{234}$ The reality is that many women attempt to leave their batterers only to discover the futility of their efforts. ${ }^{235}$ Some women may be in Judy Norman's position. They have tried repeatedly to leave, only to be hunted down and dragged back to heightened abuse and threats that the next escape attempt will be fatal-a phenomenon so common that one commentator considers it a separate quality of offense called "separation assault."236 These women have good reason to fear leaving. The risks of a battered woman being seriously injured or

233. I do not mean to suggest that Walker theorizes the former to the complete exclusion of the latter. To be certain, Walker discusses the economic and sociological barriers to escaping an abusive relationship in addition to the psychological theory of learned helplessness. The primary use of Walker's research in court, however, has concerned her description of women as helpless. As Elizabeth Schneider has noted, even if a testifying expert is cautious to emphasize a woman's individual circumstances and not her helplessness, courts hear the testimony to describe women as helpless when it is framed in the context of a syndrome. Elizabeth M. Schneider, Describing and Changing: Women's Self-Defense Work and The Problem of Expert Testimony on Battering, 9 WOMEN'S RTS. L. REP. 195, 198 (1986).

234. JACOBSON \& GOTTMAN, supra note 229 , at 165-66.

235. See, e.g., Edward Gondolf \& Ellen Fisher, BatTered WOMEn As SuRvivors: AN Alternative to Treating LeARNEd HelplessNess 92-93 (1988) (reporting that over seventy percent of battered women leave home at some time in response to violence).

236. Mahoney, supra note 5, at 65-93 (defining separation assault as "the assault on the woman's separation as a specific type of attack that occurs at or after the moment she decides on a separation or begins to prepare for one"). 
killed by her batterer are at their highest within the first two years of her separation from the batterer. ${ }^{237}$

An especially disturbing contribution to a woman's failure to leave a battering relationship is that, even when people are aware of the abuse, they often fail to protect battered women. Sarah Buel, a survivor of domestic violence, recalls one effort to leave her husband in New York and hide from him in a small town. ${ }^{238}$ She was at a crowded laundromat with her son when she looked up and saw her husband in the door. ${ }^{239}$ She began screaming, telling the people around her to call the police. Her husband responded, "No, this is my wife. We've just had a little fight." ${ }^{240}$ No one moved, so Buel pointed to the bruises still blackening her face and said, "This is the person who beat me up.... [p]lease, call the police." Her husband responded repeatedly, "No, this is my wife," and still no one moved. ${ }^{241}$ Women commonly report being beaten in front of their homes, in apartments with paper-thin walls, and in houses with open windows and doors. ${ }^{242}$ Despite a woman's pleas for help, passersby simply look the other way, and neighbors call police only to complain about the noise.

Even if someone does call authorities, the police and courts often fail to protect women from abuse. Before mandatory arrest laws, police often refused to arrest a batterer if they did not witness the abuse first hand, even if they arrived at the scene of a reported battering to find a woman covered with blood waiting for them outside. $^{243}$ Perhaps as a result of police avoidance of arrests in

237. JACOBSON \& GOTTMAN, supra note 229, at 49 (citing Margo Wilson \& Martin Daly, Spousal Homicide Risk and Estrangement, 8 VIOLENCE \& VICTIMS 3 (1993)).

238. DEFENDING OUR LIVES, supra note 230.

239. Id.

240. Id.

241. Id. Buel later became a prosecutor of domestic violence offenses and is a well known advocate for the prevention of domestic violence and assistance of domestic violence survivors. See Stephanie B. Goldberg, Nobody's Victim, A.B.A. J., July 1996, at 48, 48-51 (profiling Sarah Buel).

242. DEFENDING OUR LIVES, supra note 230.

243. Summarizing several studies of police response to domestic violence, LaViolette and Barnett report that "myth, misogyny, and misinformation" have contributed to police reluctance to intervene in family violence. Police officers may believe that the battered woman is not truly a victim if she chooses to stay, that the violence is her fault, that law enforcement intervention is not a solution, or that domestic violence situations are too dangerous to police. AlyCE D. LAVIOLETTE \& OLA W. BARNETT, IT COULD HAPPEN TO ANYONE: Why BATTERED WOMEN STAY 53-54 (2d ed. 2000). Leaving a battered woman to fend for herself against a batterer because domestic abuse scenes are supposedly too dangerous for police officers is, to say the least, ironic, but these are the types of beliefs that may cause police to avoid arresting a batterer, even if that choice 
domestic violence situations, batterers themselves do not perceive any significant risk of arrest for their conduct. ${ }^{244}$ Although mandatory arrest statutes increase the rate at which batterers are arrested, ${ }^{245}$ they also increase the likelihood that a domestic violence victim will be arrested for using defensive force. ${ }^{246}$ An unfortunate consequence is that battered women may be less likely to call the police for help if they fear they will be the partner selected for arrest or that the police, not knowing which partner was at fault, will arrest both parties. ${ }^{247}$ Even if a woman manages to leave her husband and secure a restraining order against him, the hurdles to enforcement of the order can be considerable. ${ }^{248} \mathrm{~A}$ battered woman's past attempts to resort to the police, the courts, or other avenues of escape may have failed to

requires them to disregard the law and their training. They may avoid an arrest by, for example, applying a higher standard of probable cause for domestic violence assaults or concluding that no crime has occurred. Id. at 55.

244. See Kirk R. Williams \& Richard Hawkins, The Meaning Of Arrest for Wife Assault, 27 CRIMINOLOGY 163, 170-172 (1989).

245. "Mandatory arrest" statutes require police officers to take a suspect into full custody if there is probable cause to believe that the suspect has committed a crime of domestic violence. See generally Vito Nicholas Ciraco, Note, Fighting Domestic Violence With Mandatory Arrest, Are We Winning?: An Analysis in New Jersey, 22 WOMEN's RTs. L. REP. 169, 199 (2001) (concluding that "mandatory arrest laws have varying degrees of success depending on the defined goal"); Machaela M. Hoctor, Comment, Domestic Violence as a Crime Against the State: The Need for Mandatory Arrest in California, 85 CAL. L. REv. 643, 699 (1997) (arguing that "California must allow warrantless arrest for all misdemeanor violence assaults").

246. For example, after one police department reported a twelvefold increase in arrests of women for domestic violence, with only a twofold increase in arrests of men, a study of the arrests concluded that two thirds of the arrested women had been defending themselves. See LAVIOLETTE \& BARNETT, supra note 243, at 55 (citing L.K. Hamberger \& J. Arnold, The Impact of Mandatory Arrest on Domestic Violence Perpetrator Counseling Services, 6 FAM. VIOLENCE BULL. 11 (1991)).

247. For further discussion of "dual arrest" situations, see generally Margaret E. Martin, Double Your Trouble: Dual Arrest in Family Violence, 12 J. FAM. VIOLENCE 139-57 (1997) and Daniel G. Saunders, The Tendency to Arrest Victims of Domestic Violence: A Preliminary Analysis of Officer Characteristics, 10 J. INTERPERSONAL VIOLENCE 147, 147-58 (1995). For an argument against state intervention in domestic violence against the wishes of the victim, see Linda G. Mills, Killing Her Softly: Intimate Abuse and the Violence of State Intervention, 113 HARV. L. REV. 550 (1999).

248. Mahoney, supra note 5, at 60 (discussing lawsuits that expose the failure of police to enforce restraining orders); Schopp et al., supra note 26 , at 85 ("Once a battered woman obtains a protective order, she is at the mercy of the police and legal system to enforce it."). For example, as explained by Schopp et al., police sometimes fail to arrest batterers for restraining order violations, despite state laws mandating that they do so. Schopp et al., supra note 26 , at 85 . Moreover, even when an arrest occurs, judges do not impose meaningful sanctions for restraining order violations and often blame the victim for participating in the contact from which the violation arises. $I d$. 
protect her from additional and escalating abuse, leaving her with a reasonable belief that she has no safe options. ${ }^{249}$

In other cases, however, the reasons for staying may not be so directly entwined with issues of personal safety. The economic and sociological reasons for a woman's decision to stay with a batterer are far better documented than the psychological components of the battered woman's syndrome theory. ${ }^{250}$. It may be economically infeasible for the woman to leave because she has no money, job, child care, or housing. ${ }^{251}$ One recent study found that battered women cited economic hurdles more frequently than even fear of physical retaliation as a deterrent to leaving. ${ }^{252}$ Many batterers deplete the household savings account or prevent their wives or girlfriends from having their own money. ${ }^{253}$ Battered women often suffer marked feelings of shame for the abuse they have endured, rendering them reluctant to seek help. The isolation from family and

249. Again, the extraordinary case of Judy Norman provides the relevant example. In light of her repeated, unsuccessful attempts to leave her abusive husband, several commentators have noted that she did not appear to have any reasonable alternatives to the use of deadly force. See Murdoch, supra note 7, at 214 (arguing that Norman had a reasonable belief that force was necessary in light of several futile attempts to protect herself without the use of force); Rosen, supra note 5, at 392-93 (discussing the lack of reasonable, safe options for Judy Norman).

250. See generally LAVIOLETTE \& BARNETT, supra note 243 (summarizing empirical evidence of factors contributing to a battered woman's decision to stay); Sue E. Eisenberg \& Patricia L. Micklow, The Assaulted Wife: "Catch-22" Revisited, 3 WOMEN's RTS. L. REP. 138 (1977) (arguing that the legal system "only offers the battered wife a band-aid for her wounds, both physical and psychological").

251. Debra S. Kalmuss \& Murray A. Straus, Wife's Marital Dependence and Wife Abuse, 44 J. MARRAIGE \& FAM. 277, 284-85 (1982) ("The primary group of women who tolerate severe violence are those highest in objective dependency [i.e., economic dependency].... They have virtually no alternatives to their marriages and, therefore, 'must' tolerate the conditions of those marriages.").

252. JACOBSON \& GOTTMAN, supra note 229 , at 50,166. A different study reports that a battered woman's decision to stay with a batterer correlates with the objective factor of whether the woman is employed and with tile subjective assessment of whether she is economically dependent. Michael J. Strube \& Linda S. Barbour, Factors Related to the Decision to Leave an Abusive Relationship, 46 J. MARRIAGE \& FAM. 837, 842 (1984).

253. Mahoney, supra note 5, at 63. Because the lack of income, savings, or housing places many battered women in the position of choosing between staying with an abusive partner or facing poverty and homelessness, many commentators have proposed expanding the hardship exceptions that can apply to battered women who would otherwise be exempt from receiving welfare or other public benefits. See Maria L. Imperial, Self-Sufficiency and Safety: Welfare Reform for Victims of Domestic Violence, 5 GeO. J. Fighting PoVERTY 3, 21-23 (1997); Ethan Breneman Lauer, Housing and Domestic Abuse Victims: Three Proposals for Reform in Minnesota, 15 LAW \& INEQ. 471, 497-502 (1997); Jennifer M. Mason, Buying Time for Survivors of Domestic Violence: A Proposal for Implementing an Exception to Welfare Time Limits, 73 N.Y.U. L. REV. 621, 645-52 (1998). 
friends that is common during the course of an abusive relationship further restricts potential avenues of support. ${ }^{254}$ Although the United States has more shelters for battered women than it did two decades ago, there are still not enough beds for women who need assistance when they flee abusive relationships. ${ }^{255}$ It is also common for batterers to threaten to seek sole custody of the children should the woman leave the abusive relationship. ${ }^{256}$ In these situations, a woman's escape option may be to live in a battered women's shelter while struggling to find a job and keep her kids.

Some women are coerced into remaining within abusive relationships by batterers who threaten to commit suicide if the relationship is terminated. ${ }^{257}$ The victim's feelings of responsibility for the batterer's well-being may defeat her strong desire to protect herself by leaving the abusive relationship. Opposition to divorce, whether because of a high valuation of the marital bond ${ }^{258}$ or religious commitment, ${ }^{259}$ presents an additional hurdle for married battered women.

254. Joyce McCarl Nielsen, et al., Social Isolation and Wife Abuse: A Research Report, in INTIMATE VIOLENCE 49-59 (Emilio C. Viano ed., 1992).

255. See Merle H. Weiner, From Dollars to Sense: A Critique of Government Funding for the Battered Women's Shelter Movement, 9 LAW \& INEQ. 185, 273 n.541 (1991); Joan Zorza, Recognizing and Protecting the Privacy and Confidentiality Needs of Battered Women, 29 FAM. L. Q. 273, 276 (1995); Susanne M. Browne, Note, Due Process and Equal Protection Challenges to the Inadequate Response of the Police in Domestic Violence Situations, 68 S. CAL. L. REV. 1295, 1296 (1995).

256. Mahoney, supra note 5, at 63; see also Marsha B. Liss \& Geraldine Butts Stahly, Domestic Violence and Child Custody, in BATTERING AND FAMILY THERAPY 175, 179-82 (Marsali Hansen \& Michele Harway, eds., 1993) (discussing domestic violence and its impact on abused women seeking child custody). Apparently other battered women question the ability to protect their children, even if they have physical custody. Sarah Buel states that "one of the most common reasons that many of us stay [is that] we can better protect our children if we are there and can see the abuser than if we're on the run, and he has the opportunity and advantage of being able to track us down." Sarah Buel, The Dynamics of Family Violence, in COURTS AND COMMUnITIES: CONFronting VIOLENCE IN THE FAMILY 7, 11 (Nat'l Council of Juv. \& Fam. Ct. Judges ed., 1993).

257. See Renata Vaselle-Augenstein \& Annette Ehrlich, Male Batterers: Evidence for Psychopathology, in INTIMATE VIOLENCE, supra note 254, at 139, 141 (referring to a study finding that $71 \%$ of batterers threatened to commit suicide if their partners left).

258. Frisch and MacKenzie have suggested that whether a battered woman chooses to stay or leave depends not only on the level of her belief that she is helpless, but also on the value that she places on "preserving the marital bond, 'no matter what.'" Michael $B$. Frisch \& Cynthia J. MacKenzie, A Comparison of Formerly and Chronic Battered Women on Cognitive and Situational Dimensions, 28 PSYCHOTHERAPY 339, 342 (1991).

259. See Diane Vaughn, The Long Goodbye, PSYCHOL. TODAY, July 1987, at 37-38, 42 (1987) (reporting religious conviction as one factor contributing to the continuation of unhappy marriages). 
Some women may not want to leave their abusers. The ties of love are strong enough for some battered women to justify the continuation of the relationship, despite the abuse. ${ }^{260}$ Love is a powerful incentive and can convince women that the batterer's repeated promises of change will eventually be kept. Patty Hennessy, an abused woman who eventually killed her husband, explains that "[y]ou end up staying because you really want to believe that the person you love loves you back .... Because you hate what they're doing, it doesn't mean that you hate them ... [a]nd you believe they'll change." ${ }^{261}$ Battered women may value the possibility of that change more than they do their own safety, and while many might decide differently, that decision alone does not evidence a cognitive incapacity.

To understand why a battered woman might stay in an abusive relationship, one need only consider the well-documented factors that might persuade a rational actor that her options outside of the abusive relationship are unsafe or not viable. Whereas the battered woman syndrome theory depicts domestic violence victims as homogenous, irrational, and incapacitated, a woman's continued participation in an abusive relationship can be understood by focusing upon a woman's individual circumstances and rational decision making.

\section{B. Battered Women Who Kill and Self-Defense}

Viewed as autonomous, rational actors, domestic violence victims should be held as responsible as any other actor for the consequences of their choices and their conduct. A separate question, however, is whether the standards by which all actors' conduct is to be judged are fair or reflect the values they are intended to protect. This Article advocates a version of self-defense that might apply in unusual cases to justify the killing of a batterer in nonconfrontational circumstances. Two factors distinguish this approach from the traditional standard. First, self-defense should justify uses of force that are necessary. Although necessary force would usually be in response to an imminent threat, the right to self-defense should apply whenever the force is necessary, even not in response to an imminent threat. Second, borrowing an approach that increasingly is

260. In their study of abusive relationship, Jacobson and Gottman found that many women preserve the fantasy of a loving relationship by attributing the physical abuse to their partner's alcoholism or difficult childhood. JACOBSON \& GOTTMAN, supra note 229, at 166.

261. DEFENDING OUR LIVES, supra note 230. 
used when applying traditional self-defense rules, this Article advocates that the reasonableness of the defendant's belief that force is necessary should be viewed from the perspective of a reasonable person in the defendant's situation. The consequences of these components of the approach, and the reasons behind them, are discussed in turn.

\section{Necessary Force is Justified Force}

Consider, for example, a battered woman who reasonably believes that her lethal use of force against her abuser is necessary to avoid her inevitable, but not imminent, murder. Currently, the requirement that the defendant face an imminent threat of unlawful force would defeat her self-defense claim. ${ }^{262}$ Battered women are most likely to be killed by their abusers after they leave the relationship or report abuse. ${ }^{263}$ Women should not be forced to await such a fate if they have a reasonable fear that it is inevitable, but not necessarily imminent.

The problem faced by Hennum and Norman, ${ }^{264}$ then, is a problem presented by the imminency requirement, not a problem unique to battered women. Attempting to avoid the problem by creating a specialized syndrome theory that permits battered women to avoid the imminency requirement overestimates the correlation between battered women and justified actors who use self-defense in non-confrontational moments. Not all battered women should be entitled to use force during non-confrontational moments, and not all actors who might be justified in using force without an imminent attack are battered women. ${ }^{265}$

As an initial matter, few battered women who defend themselves do so under the circumstances that initially motivated the use of the battered woman syndrome as a legal theory. Despite modern

262. As discussed in supra note 82 , the Model Penal Code's recommended relaxation of the imminency standard to a requirement of "immediate necessity" does not provide complete relief to a battered woman who needs to use force inevitably, albeit perhaps at a later time than the moment she acts.

263. See Barbara J. Hart, Family Violence and Custody Codes, 43 Juv. \& FAM. CT. J. 29,34 (1992).

264. See supra text accompanying notes $60-75$ and $76-81$ for a summary of the cases involving JoAnn Hennum and Judy Norman, respectively.

265. In a recent survey of self-defense cases, Victoria Nourse reports that claims by battered women comprised slightly more than half of all non-confrontation cases in which the imminence requirement was discussed. Nourse, supra note 17, at 1254 . Nearly forty percent of self-defense claims in non-confrontation cases were raised by male adult and juvenile defendants. Id. 
perceptions fueled by well-publicized stories of battered heroines who strike back when their abusers least suspect it, ${ }^{266}$ cases like Judy Norman's and Joann Hennum's are not typical. One researcher has concluded that only approximately twenty percent of battered women who kill an abusive spouse do so in circumstances one would characterize as non-confrontational. ${ }^{267}$ Most battered women who kill their abusers do so during a pending attack or under threat of death or serious injury and, therefore, under circumstances comporting with traditional self-defense. ${ }^{268}$ Accordingly, a theory designed to explain battered women's use of self-defense in non-confrontational situations is not necessary to assist most battered women who kill.

Despite the fact that most domestic violence victims who kill their batterers do so under traditional self-defense circumstances, the prevailing view of battered women who kill arises from a theory developed to assist the self-defense claims of women who kill in nonconfrontational circumstances. The battered woman syndrome theory has been used to carve out an exception to the traditional selfdefense requirements for a class of sympathetic defendants who used force when it was necessary to prevent an inevitable, although not imminent, attack. Widespread acceptance of the faulty assumption that non-confrontation cases are typical has buttressed the claim that it is common for battered women to behave in a manner that appears unreasonable to the average layperson, thereby lending additional support to Walker's theory of battered woman syndrome. Moreover, by assuming that most battered women who kill do so during a nonconfrontational situation, commentators have contributed to the perception that, without resort to a specialized theory that

266. See, e.g., THE BURning BED (Trimark Films 1984) (depicting a wife who was prosecuted for killing her abusive husband).

267. Maguigan, supra note 14 , at 384, 397-401 (summarizing social science research finding that between seventy and ninety percent of battered women who kill do so during a confrontation).

268. Id. Note that, although the empirical data suggest that these types of cases represent a small minority of those in which battered women kill, the dominant assumption underlying the scholarly literature is that most battered women who kill do so during a non-confrontational moment. See, e.g., Faigman, supra note 26, at 621 ("Frequently, however, a battered woman kills her mate after an attack has ended or at some time when, seemingly, no immediate threat is present."); Kit Kinports, Defending Battered Women's Self-Defense Claims, 67 OR. L. REV. 393, 409 (1985) ("The battered woman who kills her husband often does so in a non-confrontational setting."); Cipparone, supra note 216, at 436 (stating that it "often occurs" that "a woman has killed her batterer during a lull in the beatings-such as when he is asleep or when he had his back turned"); cf. Crocker, supra note 216, at 139 (stating that most appellate opinions addressing battered woman syndrome and self-defense involved non-confrontational killings). 
distinguishes battered women from other actors, the law would punish the defensive use of force by most battered women. In the end, though, the battered woman syndrome theory pathologizes and stereotypes domestic violence victims and ultimately fails to answer the question of why the battered woman who kills in a nonconfrontational moment feared imminent danger. A better approach to these atypical cases is to scrutinize the reasons for asking that question at all. In other words, why require imminency?

Outside of the context of domestic violence, Paul Robinson and others have pointed out the unnecessary rigidity of the imminency requirement. For example, Robinson hypothesizes a kidnapping victim confined by a captor who announces that the victim will be murdered in a week. ${ }^{269}$ The traditional requirement of an imminent threat would appear to prohibit a kidnap victim from using force against his sleeping jailer to escape, and would require him instead to wait until the use of force was imminent and then try to escape, possibly to his peril. ${ }^{270}$ As Robinson notes, this cannot be the preferred decision. Arguing that the imminency requirement does not properly capture the concept of necessity, Robinson argues that the proper inquiry should be the actor's need to act in defense, not the imminence of the threat. ${ }^{271}$

The heart of self-defense has always been the desire to avoid punishing actors whose conduct was necessary to self-preservation. The various rules that have been employed to define self-defense for juries all reflect an attempt to capture necessary uses of force. For example, requiring that the force used be proportional to the avoided threat serves to ensure that the defensive actor does not go beyond necessary force and inflict unnecessary revenge. ${ }^{272}$ Similarly, some

269. 2 ROBINSON, supra note $174, \S 131(\mathrm{c})(1)$, at 78 .

270. 2 Id.

271. 2 Id. Robinson's example is a good one not because it demonstrates that the hypothetical kidnap victim would in fact be prosecuted and convicted under current selfdefense standards, but because of an obvious intuition that he certainly would not be, indicating that the imminency requirement cannot be taken literally. At least one court has flirted with the hypothetical in dictum, noting that it raised questions about the appropriateness of the state's requirement of an immediate threat. State v. Buggs, 806 P.2d 1381, 1384-85 (Ariz. Ct. App. 1990). Although the court conceded that it was "imaginable" that a preemptive strike might sometimes be warranted, the court ultimately avoided the question of how a court would go about acquitting a preemptive actor by distinguishing Robinson's hypothetical actor from the actual defendant. See id. (holding that there was no need to dispense with the requirement of immediate harm when the defendant returned to the scene of the initial confrontation and fired a pistol at his targets, despite the absence of any signals that the targets intended to renew the prior attack).

272. See FLETCHER, supra note 172, at 870 (stating that only the minimal use of force necessary under the circumstances is permitted, and the force used must be in proportion 
jurisdictions bar the initial aggressor in a confrontation from claiming self-defense. ${ }^{273}$ Although this limitation has been explained as reflecting the lesser moral rights of the initial aggressor, ${ }^{274}$ it can also be seen as barring the application of the defense to conduct that, when viewed through a wider time frame, was unnecessary. Likewise, in jurisdictions that require an actor to exercise retreat options before using defensive force, ${ }^{275}$ this duty to retreat assures that claims of selfdefense are reserved to necessary uses of force.

Like these other self-defense rules, the requirement of an imminent threat attempts to limit the defense to necessary acts of force. As Richard Rosen has observed, the requirement of imminency does not serve any purpose in the self-defense analysis other than as a proxy for the more general standard of necessity. ${ }^{276}$ The requirement does not reflect a determination that imminent threats are necessarily more dangerous than non-imminent ones, or that only imminent threats are sufficiently evil to warrant avoidance. Rather, the imminency requirement results from an a priori determination that force in the absence of an imminent threat is simply unnecessary. If the threat is not imminent, then the actor is presumed to have been able to take steps to avoid the necessity of using defensive force. ${ }^{277}$

to the interest defended); LAFAVE, supra note 4, at 492 (explaining that the force used must be "reasonably related to the threatened harm which [defendant] seeks to avoid"); 2 ROBINSON, supra note $174, \S 131$ (d), at 81 ("[The] force used by an actor must be reasonable in relation to the harm threatened.").

273. See DRESSLER, supra note 4, at 224-26; FLETCHER, supra note 143, at 858; LAFAVE, supra note 4, at 497; 2 ROBINSON, supra note 174, \& 132, at 98 n.5.

274. See, e.g., FLETCHER, supra note 143, at 858 (stating that an actor's initiation of aggression lessens the value of his interests); LAFAVE, supra note 4, at 497 ("[O]ne who provokes the use of force against himself for the purpose of causing serious bodily harm may not defend against the force he has provoked.").

275. Although the modern trend has been not to require retreat, a strong minority of jurisdictions require an actor to retreat if he can do so safely. LAFAVE, supra note 4 , at 498. For further discussion of the duty to retreat, see infra notes 293-304.

276. Using Rosen's nomenclature, imminency is a "translator" for necessity. See Rosen, supra note 5, at 380; see also Stephen J. Schulhofer, The Gender Question in Criminal Law, 7 SOC. PHIL. \& POL. 105, 127 (1990) (arguing that "the traditional insistence on a literally 'imminent' infliction of great bodily harm must be abandoned outright" because the correct inquiry is the necessity of the battered woman's action rather than "imminence per se").

277. See LAFAVE, supra note 4, at 495 (explaining that imminence is required because, without it, the actor would have alternatives to the use of force and force would be unnecessary); 2 ROBINSON, supra note $174, \S 131$ (c), at 78 (noting that the imminence requirement reflects a determination that only imminent harms make an actor's response necessary); Rosen, supra note 5, at 380 ("In self-defense, the concept of imminence has no significance independent of the notion of necessity."). 
As a factor acting independent of necessity, the imminency of the threat has no exculpatory value to a claim of self-defense. ${ }^{278}$ In other contexts, the length of a defendant's opportunity to reflect upon conduct options contributes to the determination of culpability because the defendant has chosen an undesirable option. From a non-utilitarian, moral perspective, actors are deemed less culpable for wrongful decisions made in the heat of the moment, because a quick decision is deemed to be less voluntary and less indicative of poor moral character than one reached after considerable deliberation. ${ }^{279}$ Viewed from a utilitarian perspective, punishment is less likely to deter hasty errors than contemplated ones. ${ }^{280}$ In either case, that the quick nature of the decision making process is exculpatory

278. Victoria Nourse's recent empirical analysis of self-defense cases does not alter my position that imminence acts doctrinally as a proxy for necessity. Based upon her survey of self-defense cases, Nourse argues that the imminence requirement serves in practice as a proxy for self-defense factors other than the general standard of necessity. Nourse, supra note 17, at 1225 . Nourse supports her argument with a survey of self-defense cases in which she claims that courts discuss other self-defense factors under the guise of "imminence." Id. at 1305-06. She argues that court opinions discuss "imminence" even in confrontation cases where there is no time element at issue. I have two reasons for disagreeing with Nourse's conclusion that imminence acts as a proxy for several other selfdefense factors. First, even if it were true that courts apply the imminence requirement in a way that questions other self-defense requirements, it is not the case that imminence acts as a "proxy" for those factors in the way I use that term. When I say that imminence acts as a proxy for necessity, I do not mean that when courts apply the imminence requirement, they are simply asking whether force was necessary. If that were the case, I would have no objection to the imminence requirement, because it would never preclude necessary force. Rather, I mean that the underlying basis for the imminence requirement in self-defense doctrine is to ensure that force is necessary. I do not perceive Nourse as arguing that the purpose of the imminence requirement is to capture other self-defense elements; she simply argues that, as applied, the imminence requirement often captures other self-defense elements (many of which, incidentally, also act to ensure necessity). Second, Nourse's survey does not convince me that courts routinely apply the imminence requirement to capture other self-defense factors. Nourse designated a case as "imminence-relevant" even "if the court discussed imminence in terms of other issues." $I d$. at 1304. Hence, her conclusion that courts discussing imminence often do so as a means to address other issues runs the risk of being somewhat of a tautology. For example, she treats an opinion as discussing imminence as a proxy for "motive and emotion," when the court reasoned that the defendant acted out of anger and revenge, not out of fear of "imminent" danger. Id. at $1258 \mathrm{n} .114$ (discussing Commonwealth v. Pike, 701 N.E.2d 951, 956 (Mass. 1998)). An alternative, of course, would be to treat that case as not "imminence-related," since it is clear that the court's decision was about the defendant's subjective motivations, not the presence or absence of an imminent threat.

279. As Blackstone suggested, the law "respects the passions of the human mind." 3 BLACKSTONE, supra note 170 , at *3.

280. For example, Dressler writes that the primal urge to save one's life is so instinctual that "[o]ne who is threatened with immediate death is not deterrable by the threat of criminal sanction. Therefore, his punishment is inefficacious." DRESSLER, supra note 4, at 233 . 
presupposes that the actor's decision was objectively undesirable. In other words, the actor's wrongful decision is excused because of the quickness with which he was forced to act. Insistence upon the lack of an opportunity to contemplate one's conduct is wholly misplaced when the defense is a justification and not an excuse. To require that the circumstances preceding the defensive use of force mandate a quick reaction-even when the use of force is objectively necessaryturns the traditional utilitarian and retributive rationales for timefocused elements on their heads and transforms self-defense into an excuse.

Advocates of the imminency requirement argue that to permit the use of force absent an imminent threat of harm is to encourage vigilantism. ${ }^{281}$ For example, they argue that, without the imminency requirement, actors would be permitted to engage in "self-help" even when there was sufficient time to seek police assistance. ${ }^{282}$ This argument, however, presumes that the use of force in a nonconfrontational situation is always unnecessary. Because the requirement of imminency is an imperfect proxy to ensure that a defendant's use of force is necessary, a better standard would require that the use of force be necessary. Requiring that the defendant have a reasonable belief that the use of force was necessary for self-

281. See Susan Estrich, Defending Women, 88 MICH. L. REV. 1430, 1431-32 (1990) ("[T]he imminence requirement is at least intended as a limit on vigilante revenge for attacks on one's family that occurred hours or days before."); Rosen, supra note 142, at 53-54 (arguing that relaxation of the imminence requirement undermines the notion of self-defense as a justification, because it permits non-confrontational defensive force, which is not socially desirable); Lauren E. Goldman, Note, Nonconfrontational Killings and the Appropriate Use of Battered Child Syndrome Testimony: The Hazards of Subjective Self-Defense and the Merits of Partial Excuse, 45 CASE W. RES. L. REV. 185, 205-06 (1994) ("Only by ... maintaining the integrity of an objective standard of imminence can society be sure that self-defense claims in nonconfrontational situations are rooted in necessity rather than retribution."). A recent comment worries specifically about the use of preemptive self-defense by inmates in prison. See Veinsreideris, supra note 222 , at $628-39$. Defenses invoked by prisoners threatened by other inmates have caused notable consternation among the courts, perhaps because of fears of fabricated claims of abuse, but more likely because of discomfort conceding that such abuse is rampant in American prisons. In any event, the same concerns raised in this context by elimination of the imminence requirement for self-defense currently arise when prisoners claim duress or necessity. Courts unwilling to trust juries in this unusual context to apply the broad legal standards defining these defenses have favored court-made rules. See People v. Lovercamp, 118 Cal. Rptr. 110,112 (Cal. Ct. App. 1974).

282. Cathryn Jo Rosen argues that relaxation of the requirement would encourage vigilantism because "the logical corollary is that any person who believes, reasonably or unreasonably, that the criminal justice system does not offer adequate protection can resort to self-help even though there may have been sufficient time to summon the aid of lawful authority." Rosen, supra note 142, at 54. 
protection $^{283}$ avoids by definition the extension of the defense to unnecessary and therefore unjustified uses of force. ${ }^{284}$ And, although in most situations, the avoided threat would need to be imminent in order for self-protection to be necessary, Robinson's hypothetical kidnap victim demonstrates that the standard of necessity can be met even when imminence is absent. The battered woman syndrome theory may permit an end-run around the imminency requirement for domestic violence victims, but it does not remedy the underlying formal doctrinal problem. As one court astutely noted, the current standard's requirement of an imminent threat-even in conjunction

283. This Article does not seek to define the precise scope of the nature of the harms that the defendant must seek to avoid in order to claim self-defense. For current purposes, it is sufficient simply to avoid a potential point of confusion that may be created by the "necessity" verbiage. By relying on a generalized standard of necessity for defensive force, I do not intend to require in a self-defense claim the strictly utilitarian balancing of harms that is typical to a defense of "necessity" outside of the self-defense context. For example, when a defendant claims that "necessity" justifies the destruction of property to prevent the spread of a fire, the defense of necessity applies only if the harm that the actor sought to avoid is greater than the harm that his chosen course of conduct inflicted. See MODEL PENAL CODE $\$ 3.02$ (1985) (providing "choice of evils" defense applicable when "the harm or evil sought to be avoided by such conduct is greater than that sought to be prevented by the law defining the offense charged"). Self-defense norms do not typically require that type of harm-balancing, and I do not advocate any such change. Nourse has correctly noted, for example, that one cannot discuss imminence in a vacuum, because defendant may face an imminent attack, but one that is not deemed serious enough to warrant a deadly response. Nourse, supra note 17, at 1276-77. Just as advocating an imminence requirement does not answer the question of "imminent threat of what harm?," my advocacy of a necessity requirement is not intended to answer the question of "necessary to avoid what harm?" The Model Penal Code, for example, permits deadly physical force to defend against not only death, but also serious bodily harm, kidnapping, or rape. MODEL PENAL CODE $\$ 3.04$ (1985). Whatever the scope of the harms against which a jurisdiction permits defense, my argument is that the threat of such harm need not be imminent if the actor has a reasonable belief that force is necessary to avoid the proscribed harm.

284. It is for this reason that I disagree with Maguigan's suggestion that elimination of the imminency requirement would help the perpetrators of domestic violence more than its survivors. Maguigan's argument is that, because men who kill female partners far outnumber the women who kill male partners, any expansion of defensive force standards "would probably not maximize the safety" of battered women. Maguigan, supra note 14, at $449 \&$ n.245. Her inference from these statistics assumes, however, that among the men and women who kill are proportionate numbers of actors whose uses of force were necessary despite the lack of an imminent threat. The reasons for making this assumption are unclear in light of the fact that the vast majority of perpetrators of domestic violence are men, Mahoney's theory that men (and not women) perceive separation from a confrontation as "losing," and the fact that men who kill during non-confrontational moments claim self-defense at a lower rate than similarly situated women. See Mahoney, supra note 5, at 64 (explaining that women are more likely than men to see safe retreat from a confrontation as prevailing); Nourse, supra note 17, at 1254 (reporting that battered women comprised most of the defendants in non-confrontation self-defense cases in which the imminent requirement was discussed). 
with the battered woman syndrome theory-renders the defense inapplicable when a battered woman who faces no imminent threat reasonably concludes that homicide or suicide are her only possible long-term means of escaping an abusive relationship. ${ }^{285}$

George Fletcher's advocacy of the imminency requirement adopts a slightly different slant on the vigilantism argument. He has argued that the requirement of imminency is politically necessary to a theory of justification, because only in the presence of an imminent threat can the governed trust that the state has appropriately delegated its right to use force against lawbreakers and is not authorizing the populace to "take the law into its own hands" and use retaliatory force. ${ }^{286}$ His argument is to some extent circular because one does not take the law into her own hands by doing what the law permits, and the debate is about what types of defensive force the law should permit. For example, as discussed further below, many jurisdictions permit the defensive use of force in response to an imminent threat, even if the defensive actor could have safely retreated from the confrontation. ${ }^{287}$ Why is the state's delegation of the use of force to a man who can safely retreat from an imminent threat any more legitimate to the populace than delegation to a woman who reasonably believes that she cannot retreat from a non-

285. State v. Leidholm, 334 N.W.2d 811, 820 n.8 (N.D. 1983). Nothing about the battered woman syndrome theory changes this result. In Leidholm, the North Dakota Supreme Court adopted what is perhaps the most expansive approach to self-defense advocated by supporters of the battered woman syndrome theory. The court adopted a "subjective" standard of reasonableness, requiring the jury to consider the defendant's conduct not from the standpoint of a reasonable person, but from the perspective of what the defendant herself "in good faith honestly believed and had reasonable ground to believe" in light of her prior knowledge and unique psychological and physical characteristics. Id. at 818 (citing State v. Hazlett, 113 N.W. 374, 380 (N.D. 1907)); see also State v. Wanrow, 559 P.2d 548, 558-59 (Wash. 1977) (adopting a "subjective" standard of reasonableness and concluding that a self-defense instruction using masculine pronouns to describe the defensive actor violated the equal protection rights of a female defendant who was five feet and four inches tall with her leg in a cast). The court ultimately conceded, however, that if there was no "reasonable" belief of imminent unlawful harm, even under this psychologically-individualized standard of reasonableness, "the defendant perhaps should consider abandoning" a self-defense claim, even though she believed (and reasonably so) that the use of force was necessary. See Leidholm, 334 N.W.2d at 820 n.8; see also Ha v. State, 892 P.2d 184, 192 (Alaska Ct. App. 1995) (citing State v. Stewart, 763 P.2d 572, 577-79 (Kan. 1988) (although the court would generally permit jurors to consider self-defense claim from the perspective of the "reasonably prudent battered wife," a self-defense instruction could not be given when the victim was sleeping and there was no imminent danger).

286. George P. Fletcher, Domination in the Theory of Justification and Excuse, $57 \mathrm{U}$. PITT. L. REV. 553, 556-58, 567-71 (1996).

287. See infra notes 293-304 and accompanying text for further discussion of the duty to retreat. 
imminent threat? More importantly, it is not at all clear that the legal standard for defensive force should conform to popular beliefs about when defensive force is necessary, if those beliefs are inaccurate. Fletcher compares a battered woman's necessary preemptive strike to conflicts between states, where, for example, Israel and Iraq argue about whether force in the absence of an imminent threat is retaliatory or preemptive. ${ }^{288}$ Although provocative and, at first glance, appealing, the individual/sovereign analogy falls short because it ignores the everyday role that jurors play in American criminal cases. To permit armies to engage in preemptive attacks is disastrous in part because there is no feasible and credible process for resolving a dispute about whether an attack is necessary. In contrast, we regularly entrust juries to apply generalized standards to resolve disputes about the blameworthiness of individual, rather than sovereign, conduct ${ }^{289}$

Combined with the rational actor approach to understanding the continuation of domestic violence relationships, a necessity standard for self-defense would permit some victims of domestic violence to claim self-defense even in non-confrontational situations. For example, consider a woman who remained in a violent domestic relationship because she tried multiple times to leave only to be tracked down, beaten, and dragged back home, a phenomenon so common that Martha Mahoney has coined it "separation assault." 290 Suppose, in addition, that after the most recent and most aggravated separation assault, the batterer stated that if she ever tried to leave again, he would track her down and this time kill her, himself, and their children. If the woman were to kill her husband in his sleep, a necessity-based theory of justification would permit the woman to present a claim of self-defense for jury decision. ${ }^{291}$

288. Fletcher, supra note 286, at 556-58, 570 .

289. Consider, for example, the considerable relaxation of the bright-line rules that previously determined when murder could be reduced to voluntary manslaughter. At common law, a series of defined categories of occurrences were recognized as adequate provocation, including physical attack, mutual combat, unlawful arrest, and the witnessing of adultery. See MODEl Penal CODE $\$ 210.3 \mathrm{cmt}$. 5(a) (Official Draft 1980). Under the modern approach, these rigid definitions of provocation have given way to a generalized standard of provocation that jurors are entrusted to apply. See, e.g., MODEL PENAL CODE $\S 210.3(1)$ (1985) (reducing homicides that would otherwise be murder to manslaughter if committed "under the influence of extreme mental or emotional disturbance for which there is reasonable explanation or excuse").

290. Mahoney, supra note 5, at 6 (proposing recognition of "separation assault").

291. Some commentators have argued that the requirement of imminency should not apply or should be waived in cases involving violent intimate relationships, without noting that the requirement is problematic in other contexts as well. E.g., Alene Kristal, Note, 
Despite its elimination of a requirement of imminency, a standard of necessity for defensive force is in one important respect more stringent than the self-defense standard used in many jurisdictions. ${ }^{292}$ A duty to retreat from a threatening situation before using force inherently follows from a requirement that defensive force be necessary. ${ }^{293}$ Nevertheless, contemporary American criminal law has backed away from the common law duty to retreat. ${ }^{294}$ This expansion of the common law self-defense doctrine reflects the view that a "true man"295 has a "divine right" 296 to "stand his ground"297

You've Come a Long Way, Baby: The Battered Woman's Syndrome Revisited, 9 N.Y.L. SCH. HUM. RTS. J. 111, 155-56 (1991) (arguing that the imminent harm requirement "should be relaxed somewhat" for cases arising from battering situations, and stating that the requirement is "more appropriately applicable to the traditional equal force scenario").

292. Others who have advocated the elimination of the imminency rule in favor of a necessity standard appear to view the change as an expansion of self-defense norms. See Rosen, supra note 5, at 404. Richard Rosen asserts that the suggested change "imports no new norms into the law of self-defense; it merely changes the locus of decision making" by shifting from the legislature to the jury the responsibility to decide when force is necessary. Id. At least implicitly, however, Rosen describes the change as an expansion of the right to self-defense and appears to assume that the approach would lead to more and not fewer self-defense instructions. See id. He does not explicitly acknowledge that the battered woman syndrome theory is used currently to claim self-defense even when the force is unnecessary, nor does he advocate a retreat from the theory's current acceptance and use. See id. at 410-11; see also Murdoch, supra note 7, at 213 (arguing for elimination of the imminency requirement, but still applying the battered woman syndrome theory).

293. See State v. Leidholm, 334 N.W.2d 811, 820 (N.D. 1983) ("[B]efore it can be said that the use of deadly force is 'necessary' to protect the actor against death or serious injury, it must first be the case that the actor cannot safely retreat from the assailant with safety to himself and others."). See generally RICHARD MAXWELL BROWN, No DUTY TO RETREAT (1991) (discussing the historical context surrounding the American rejection of the duty to retreat); Joseph H. Beale, Jr., Retreat from a Murderous Assault, 16 HARV. L. REV. 567, 573-82 (1903) (discussing the duty to retreat); Garrett Epps, Any Which Way But Loose: Interpretive Strategies and Attitudes Toward Violence in the Evolution of the Anglo-American "Retreat Rule," 55 LAW \& CONTEMP. PROBS. 303 (1992) (describing the development of the retreat rule); Yolanda R. Mitchell, Criminal Law-No Longer a Duty to Retreat-Chapter 696 of Mass. Acts of 1981, 67 MASS. L. REV. 89, 89-90 (1982) (describing the adoption of the no-retreat rule in Massachusetts).

294. See Beard v. United States, 158 U.S. 550, 560-64 (1895); Idrogo v. People, 818 P.2d 752, 756 (Colo. 1991) (en banc); Erwin v. State, 29 Ohio St. 186, 186, 193, 199 (Ohio 1876). Although there is a clear split among jurisdictions regarding an actor's duty to seek safe retreat options, the majority approach is generally described as rejecting a duty to retreat. See DRESSLER, supra note 4, at 227; LAFAVE, supra note 4, at 498.

295. In a famous rejection of the duty to retreat, the Supreme Court of Ohio reasoned that, although the criminal law reflects "tenderness for human life and the frailties of human nature, ... a true man, who is without fault, is not obliged to fly from an assailant, who by violence or surprise maliciously seeks to take his life or do him enormous bodily harm." Erwin, 29 Ohio St. at 199-200. For an overview of the historical context surrounding the American rejection of the duty to retreat, see BROWN, supra note 293, at 4-30. 
when threatened, and that any requirement of cowardice would violate American values. ${ }^{298}$ To facilitate these traditionally masculine notions of autonomy, the prevailing self-defense standard expands the right of self-defense even beyond force necessary for selfprotection, by rejecting a duty to retreat. ${ }^{299}$ At the same time, the traditional standard's imminency requirement makes it more difficult for women to engage in justified defensive force, because it forces actors to wait until a threat is imminent, even if force is necessary at an earlier opportunity. Changing current self-defense doctrine to require only necessity, not imminency, would make the defense more equitable and give women the same opportunity as men to "stand their ground." 300

Imposing a duty to retreat need not, however, prove fatal to a battered woman's self-defense claim. The duty to retreat does not require the actor to retreat at all costs. ${ }^{301}$ It imposes a duty to retreat

296. Miller v. State, 119 N.W. 850,857 (Wis. 1909).

297. See id.

298. For example, one Indiana court saw the duty to retreat as violating "the tendency of the American mind" and "the law of nature." Runyan v. State, 57 Ind. 80, 82 (1877).

299. As Susan Estrich has noted, conversely, to impose a duty to retreat is to limit "the manly instinct to stand one's ground and fight." Estrich, supra note 281, at 1432. Estrich favors the retreat requirement because it calls upon men "to sacrifice this aspect of manhood to the preservation of human life." Id. From another perspective, however, complying with the retreat rule may be the true demonstration of real manliness. As one author wrote, "[a] really honorable man ... would perhaps always regret the apparent cowardice of a retreat, but he would regret ten times more ... the thought that he had the blood of a fellow-being on his hands." Beale, supra note 293, at 581. Martha Mahoney uses the following anecdote to demonstrate gender differences in the response to retreat: A woman tells a man in a bar that if she fought off a man who attacked her and then ran away, she would consider herself the winner and the attacker beaten. The man in the bar responds that, no, she lost because she had to run away. The woman's perception is that she won by staying safe and protecting herself. Mahoney, supra note 5, at 64 (explaining the role that gender-differenced perceptions of control may play in the separation assault phenomenon).

300. Charles Ewing has suggested an alternative way to level the self-defense playing field. Ewing notes that traditional self-defense already permits lethal self-defense that is not utility maximizing by, for example, not requiring defensive actors to retreat and justifying killings in response to threats of serious physical injury. He advocates the recognition of an additional justification for lethal self-defense against "extremely serious psychological injury." Ewing, supra note 8, at 581-89. My approach equalizes the law of self-defense by limiting, rather than expanding, the justification of force other than to protect physical integrity.

301. For purposes of this Article, I remain agnostic about whether the duty to retreat should have a "castle exception" (under which a defensive actor need not leave his or her home), or whether such an exception should have a "co-habitor exception" that would reimpose the duty to retreat if the assailant also resides in the home. It seems to me that a properly constructed duty to retreat, which requires an actor to pursue retreat options only if they are completely safe, would rarely be an unfair hindrance to a justified defensive claim if the jurors were informed of the reasons why escape was unsafe. Even 
if it is safe to do so. ${ }^{302}$ An honest and reasonable belief that the actor cannot safely retreat satisfies the duty. ${ }^{303}$ A battered woman who kills out of necessity would be able to show that she could not safely retreat at the moment she acted, if she were able to introduce evidence about the realities of the circumstances that made retreat unsafe and the use of force necessary. ${ }^{304}$ Because jury consideration of the defendant's circumstances would be essential to a battered woman's ability to show that she reasonably believed that force was

under the prevailing approach, the retreat rule is only rarely at issue when battered women kill. See Maguigan, supra note 14 , at 420 \& n.142 (reporting that the retreat rule was at issue in only twelve percent of the cases in the studied sample). If the argument over the duty to retreat is instead viewed as a fundamental question of whether a battered woman (or any actor) should be forced to retreat from her own home, I view this as raising the same normative issues raised by the question of what types of threatened harms justify deadly physical force. See supra note 283.

302. See, e.g., State v. Anderson, 631 A.2d 1149, 1155 (Conn. 1993) (rejecting the majority no-retreat rule but holding that a jury instruction was erroneous for failing to explain that the actor must have an option to retreat to complete safety; "the term 'complete safety' connotes a standard that is more absolute than mere 'safety' "); State v. Gardner, 104 N.W. 971, 975 (Minn. 1905) ("Self-defense has not, by statute nor by judicial opinion, been distorted, by an unreasonable requirement of the duty to retreat, into selfdestruction.").

303. See State v. Leidholm, 334 N.W.2d 811,820 (N.D. 1983). In some jurisdictions, the belief need only be honest. In other words, a retreat requirement applies only if the actor is subjectively aware of the existence of a safe retreat option. See State v. Ash, 651 A.2d 247, 252 (Conn. 1994); Redcross v. State, 708 A.2d 1154, 1158 (Md. Ct. Spec. App. 1998). Joshua Dressler, for example, advocates for the retreat requirement as an extension of the necessity principle, but believes that the requirement applies only when the defendant is subjectively aware of a place of complete safety to which she can turn. DRESSLER, supra note 4, at 227-28. A requirement of objective reasonableness, however, is more consistent with the general principle that the right to use force in self-defense does not rest solely upon the actor's subjective beliefs about the necessity of force.

304. On the issue of retreat, my argument closely tracks the sentiments of Schneider, Maguigan, and Mahoney toward the imminence requirement. These commentators have argued that formal changes to the doctrinal requirement of imminence would be unnecessary if jurors understood the realities of the lives of domestic violence victims. See supra note 14. Although I believe that the imminency requirement is still a hurdle even with a contextualized self-defense standard, I agree with their approach with respect to the duty to retreat. Jurors who are fully informed of the individual circumstances surrounding a defendant's decision to use force would be able to determine whether the defendant had reasonably safe alternatives that she should have pursued instead. Curiously, Maguigan appears to have more resistance to the duty to retreat than the imminence requirement. For example, she argues that the duty to retreat must at least contain a "castle exception" to remove an impediment for claims of self-defense arising from family violence, but believes that evidence of separation assault can be used to support the defendant's belief that a threat is imminent, and that elimination of the imminency requirement might permit more batterers to claim self-defense. Compare Maguigan, supra note 14 , at 451 (advocating the castle exception to the duty of retreat), with id. at 449 (arguing that eliminating the imminence requirement would probably not "maximize the safety of women's lives" because more men kill women partners than vice versa). 
necessary (and retreat was unsafe) at a nonconfrontational moment, I turn next to the question of what "circumstances" the jury should consider when determining whether the defendant's beliefs were "reasonable."

\section{An "Objective" Contextualization of the Reasonableness Standard}

Under the approach that I advocate, a defendant would be entitled to a self-defense instruction whenever there is sufficient evidence to support a reasonable belief that her conduct was necessary. In this context, what does it mean to say that the defendant's beliefs were "reasonable?" And what evidence should the jury be permitted to consider in determining the reasonableness of the defendant's belief that the use of force was necessary? The exploration of these questions must begin with a clarification of terms.

An ongoing theme in the scholarly debate about self-defense is the tension between "objective" and "subjective" standards for judging self-defense claims. ${ }^{305}$ Unfortunately, the objective-subjective dichotomy is often invoked to reflect three separate dualities, each with differing significance in the self-defense debate. First, the terms are used to describe the governing standard that applies to the defendant's belief that force is justified. In this first context, the objective-subjective terminology does not present a matter of significant debate. "Subjective" is used to reflect the requirement that the defendant have an actual and honest belief that her conduct was justified. ${ }^{306}$ "Objective" is used to describe the requirement that the defendant's belief be measured against the beliefs of a reasonable person. ${ }^{307}$ Here, the self-defense standard is well settled. Every jurisdiction requires both that the defendant have an actual and honest belief that her conduct is justified, and that the defendant's

305. See generally Heller, supra note 136 (discussing the objective/subjective debate); Kelman, supra note 136 (same); Cynthia Kwei Yung Lee, Race and Self-Defense: Toward a Normative Conception of Reasonableness, 81 MINN. L. REV. 367, 381-91 (1996) (same); Maguigan, supra note 14, at 409-13 (same); Nourse, supra note 17 (same); Kenneth W. Simons, Self-Defense, Mens Rea, and Bernhard Goetz, 89 ColUM. L. REv. 1179, 1185-91 (1989) (book review) (same).

306. E.g., People v. Humphrey, 921 P.2d 1, 14 (Cal. 1996) (referring to defendant's actual belief as the "subjective" prong of the self-defense standard); State v. Stewart, 763 P.2d 572, 579 (Kan. 1988) (referring to the requirement that defendant have a sincere and honest belief in the need to defend as the "subjective" prong of the self-defense standard).

307. E.g., Humphrey, 921 P.2d at 14 (referring to the requirement that defendant's belief be reasonable as the "objective" prong of the self-defense standard); Stewart, 763 P.2d at 579 (same). 
belief be reasonable. ${ }^{308}$ To avoid confusion, this Article refers to the "subjective" and "objective" requirements in this context as the "actual, honest beliefs" requirement and the "reasonableness" requirement, respectively.

A second use of the objective-subjective dichotomy is to describe whether a jurisdiction considers circumstances that are specific to an individual defendant when applying the universal requirement that the defendant's beliefs be reasonable. In this context, a "subjective" standard of reasonableness compares the defendant's beliefs to those of a hypothetical reasonable person who stands in the defendant's shoes, knowing what the defendant knows, seeing what the defendant sees. ${ }^{309}$ In contrast, a wholly "objective" standard of reasonableness compares the defendant's beliefs to those of a hypothetical reasonable person, without taking into account the individual circumstances of the defendant.

Within this second context of describing the requirement that the defendant have a reasonable belief that force is necessary, the objective-subjective dichotomy is also misleading. Even the so-called "subjective" version of the reasonableness standard still requires that the defendant's beliefs be more than actual and honest, but also reasonable. For that reason, the objective-subjective terminology becomes a false dichotomy in this context and loses its descriptive

308. See Maguigan, supra note 14 , at $409 \mathrm{n} .105$ ("[A]11 jurisdictions require that the defendant have a subjective, actual, and honest belief in the necessity of using deadly defensive force."); Nourse, supra note 17, at 1290 ("There is no jurisdiction in the United States that adopts a purely subjective self-defense standard (for women or anyone else)." (emphasis in original)). Although some commentators have cited the Model Penal Code as employing a wholly subjective standard for the belief that force is necessary, see LAFAVE, supra note 4, at 494, the Model Penal Code does employ an objective standard when self-defense is asserted as a perfect defense. See MODEL PENAL CODE $\$ 3.09$ (1)(a) (1985). Section 3.04(1) of the Model Penal Code initially employs a wholly subjective standard for the defendant's belief that force is necessary. Id. $\$ 3.04$ (1) (justifying use of force "when the actor believes that such force is immediately necessary for the purpose of protecting himself."). However, the Code goes on to provide that when the defendant is reckless or negligent in his belief that force is justified, he is prohibited from asserting selfdefense, unless the charges against him require only recklessness or negligence as the mens rea. Id. $\$ 3.09(2)$. In other words, when a defendant's belief is not objectively reasonable, self-defense operates only to reduce a crime requiring purpose or knowledge to a lesser offense requiring only recklessness or negligence.

309. See Maguigan, supra note 14, at $409 \mathrm{n} .105$ (noting that one use of the term "subjective" is to describe the reasonableness standard of the defendant's honest and actual belief, placing "the hypothetical reasonable person in the situation of and having the information available to and the experience and perceptions of the defendant on trial"); Nourse, supra note 17, at 1278-79 (describing the "subjectivized" approach to selfdefense as permitting juries and judges to understand the individual defendant's experiences). 
value. For example, in State v. Wanrow, ${ }^{310}$ the court reversed the conviction of a battered woman who killed her husband, because the trial court had used an inappropriate, "objective" standard of reasonableness. ${ }^{311}$ However, while purporting to reject objectivity, the court simply held that the "justification of self-defense is to be evaluated in light of all the facts and circumstances known to the defendant, ${ }^{, 312}$ and must take into account the defendant's gender. ${ }^{313}$ Compare the court's reasoning in People v. Goetz, ${ }^{314}$ where the court reinstated the indictment against infamous subway killer Bernard Goetz. ${ }^{315}$ The Goetz court, like the court in Wanrow, held that the reasonableness determination must reflect the defendant's background, experiences, knowledge, and physical attributes. ${ }^{316}$ However, the court described this standard of reasonableness as "objective." 317 Because the objective-subjective dichotomy inappropriately describes the debate over whether to consider the defendant's individual circumstances when applying the reasonableness standard, this Article avoids using those terms in this context. This Article refers instead to a "contextualization" of the reasonableness standard, which takes into account the circumstances surrounding the defendant's beliefs. In contrast, a "non-contextual" reasonableness standard would measure the defendant's beliefs against those of a hypothetical reasonable person, without taking into account the individual characteristics of the defendant.

Many commentators have suggested that the recent debate between objectivity and subjectivity is about whether to contextualize

310. 559 P.2d 548 (Wash. 1977).

311. Id. at 559 .

312. Id. at 555 (emphasis in original).

313. Id. at $558-59$.

314. 497 N.E.2d 41 (N.Y. 1986).

315. Id. at 44. Goetz shot four African-American youths after two of the men in the group approached him on a subway train and asked him for five dollars. Id. at 43 . According to his statements to police, Goetz, a previous robbery victim, determined from the victims' facial expressions that they were going to rob and assault him. Id. at 44 . He drew a gun and aimed at the centers of the victims' bodies, wanting to inflict as much suffering as possible. See id. When he saw that one was unharmed, he said, "[y]ou seem to be all right, here's another," and then fired a bullet that severed the youth's spinal cord, paralyzing him. Id. Although the New York Court of Appeals reinstated the charges against Goetz, id. at 54, a jury ultimately acquitted him of the most serious charges. Kirk Johnson, Goetz is Cleared in Subway Attack; Gun Count Upheld, N.Y. TIMES, June 17, 1987, at A1.

316. Goetz, 497 N.E.2d at 52.

317. Id. at 48; see also Wanrow, 559 P.2d at 558-59 (applying an "objective" standard but considering "individual physical handicaps which are the product of sex discrimination"). 
the reasonableness standard. ${ }^{318}$ This suggestion is frequently made by holding up battered women as worthy candidates for a contextualized standard, and contrasting acquitted subway-killer Bernard Goetz as the undeserving beneficiary. ${ }^{319}$ The argument is that permitting jurors to evaluate the need for self-defense from the perspective of a battered woman's individual circumstances sets the stage for Bernard Goetz's reliance upon racial and other stereotypes when he claims that any "reasonable" person would fear being robbed by a group of young, black men. ${ }^{320}$ Contrary to this argument's premise, however, the contextualization of the reasonableness question is neither novel nor controversial. In fact, a wholly non-contextual standard of

318. See supra note 309.

319. See, e.g., Armour, supra note 136, at 783 (discussing Goetz as a disturbing example of the use of race-based evidence and arguments); Sanford H. Kadish, Fifty Years of Criminal Law: An Opinionated Review, 87 CAL. L. REv. 943, 978 (1999) (noting that the contextualization of the self-defense standard for battered women forces courts to confront claims like Goetz's); Kahan \& Nussbam, supra note 143, at 332 (proposing that an "evaluative" account of emotion in the law recognizes that battered women should not be required to forego violence as the expense of degradation and humiliation, distinguishing their self-defense claims from those, like Goetz, who are "impelled to violence by intense but morally inappropriate emotions"); Kelman, supra note 136, at 81214 (questioning whether contextualization should be permitted for battered women and not subway killers); Lee, supra note 305 , at $416-423$ (invoking the Goetz trial as demonstrative of how racial stereotypes about young black males can bolster a white male defendant's claim that he acted reasonably in self-defense); Shirley Sagawa, $A$ Hard Case for Feminists: People v. Goetz, 10 HARV. WOMEN's L.J. 253, 272 (1987) (concluding that the difference between battered women and Goetz is that the former are "outside" the legal system).

320. My own position is that Goetz's acquittal was the result of jury nullification, not the contextualization of the reasonableness standard. Goetz's own statements to the police showed that he did not have even an actual and honest, let alone reasonable, belief that his use of force was necessary. Accord Heller, supra note 136, at 89 n.310 (observing that Goetz did not appear to have even a "subjective" belief that self-defense was necessary). For example, Goetz admitted that he was certain that none of the youths whom he shot had a gun, that the boys were trying to get away from him when he shot them, and that his intention was "to make them suffer as much as possible." Goetz, 497 N.E.2d at 44. After checking to make sure that the first two victims had been "taken care of," he shot another in the back, saying, "[y]ou seem to be all right, here's another." Id. Because the Goetz acquittal appears to be the product of the jury's refusal to apply the governing legal standards, the undesirability of that outcome says nothing about the desirability of the standards themselves. Even if Goetz had an actual and honest belief that his conduct was necessary, several commentators have set forth compelling reasons to prohibit treating racism as reasonable, even using a contextualized standard. See, e.g., Kahan \& Nussbam, supra note 143, at 332 (distinguishing the self-defense claims of battered women from those, like Goetz, who are "impelled to violence by intense but morally inappropriate emotions"); Kelman, supra note 136, at 815-16 (arguing that the most persuasive reason to reject the subway killer's contextualizing evidence is that the societal costs of his error are more unacceptable than for the mistaken battered woman); Sagawa, supra note 319 , at 272 (concluding that the difference between battered women and Goetz is that the former are "outside" the legal system). 
reasonableness is difficult to fathom. For example, if the defendant stabbed a person who was holding a gun to his head and threatening to pull the trigger, a jury would certainly be permitted to consider the defendant's "circumstance" of having a loaded gun to his head when determining the reasonableness of his belief that the stabbing was necessary. The debate over contextualizing the reasonableness standard, therefore, is not about whether or not to do so.

Rather, the controversy over reasonableness arises in the third context of the objective-subjective dichotomy. In this context, the question is whether the jury should evaluate the reasonableness of the defendant's conclusion that force was necessary from the perspective of what a reasonable person would believe to be true about the surrounding factual circumstances, or, rather, from the perspective of what the defendant actually and honestly believed about the surrounding factual circumstances. ${ }^{321}$ For example, consider a defendant who actually and honestly, but wholly irrationally, believed that the victim was about to light him on fire. A "subjective" approach to contextualization would require the jury to accept the defendant's beliefs about the factual circumstances to be true, and then determine whether a reasonable person would have believed that force was necessary when the victim was about to ignite him. An "objective" approach to contextualization requires an initial evaluation of the defendant's beliefs about the factual circumstances (i.e., whether a reasonable person would have believed that the victim was going to ignite the defendant).

A different way to describe this dichotomy is by using the objective-subjective terminology to describe, not the standard of reasonableness, but the types of circumstances that the jury must take into account when assessing reasonableness. ${ }^{322}$ The "objective" approach instructs the jury to determine what a reasonable person would have believed given the objective, factual circumstances. For example, the jury might take into account the size of the defendant,

321. For example, in Leidholm, the court adopted a so-called "subjective" standard of reasonableness. State v. Leidholm, 334 N.W.2d 811, 821 (N.D. 1983). The court held that the relevant inquiry was not whether the surrounding circumstances would be sufficient to cause a reasonable person to believe that force was necessary, but rather whether the circumstances were such that the defendant himself had an honest and reasonable belief that he must use force. Id. at 820-21; see also Lee, supra note 305 , at 385 (describing a subjective standard of reasonableness as "one that views as reasonable those beliefs that the defendant sincerely thinks are reasonable").

322. See, e.g., Simons, supra note 305, at 1189 (questioning whether the Goetz jury should have considered Goetz's prior robbery victimizations and his resulting nervousness, and raising the question of "how 'objective' is the objective test?"). 
prior threats by the victim against the defendant, the victim's movements preceding the incident, and so on. ${ }^{323}$ The "subjective" approach takes into account subjective factors, permitting the individualization of the standard to accommodate the defendant's psychological peculiarities. For example, an unusually paranoid defendant might be quick to conclude that a man in a parking lot is following her, even when a reasonable person (including reasonable women) would not, given the objective circumstances. The subjective approach to contextualization would ask the jury to determine whether a reasonable person suffering from defendant's heightened paranoia would believe that self-defense was necessary.

Once the different uses of the objective-subjective terminology are unpacked, it is clear that the heart of the debate is not whether to use an objective or a subjective standard for self-defense, but whether to consider objective or subjective circumstances when applying an objective standard. The advocates of the battered woman syndrome have stretched the bounds of self-defense not by contextualizing the reasonableness standard ${ }^{324}$ but by asserting that the defendant's subjective peculiarities should be transposed upon the hypothetical reasonable person.

The better approach is to contextualize the reasonableness standard by instructing jurors to consider the objective factual circumstances surrounding the battered woman's use of force when determining whether the force was reasonable. In determining whether a defendant had a reasonable belief that the use of force was necessary, ${ }^{325}$ the jury would be required to determine what a

323. What I call the objective approach to contextualization has been offered by feminist scholars like Elizabeth Schneider. SCHNEIDER (2000), supra note 14, at 124 ("Evidence of batte'ing in a self-defense case is not relevant to justify the killing, but it provides the jury with the appropriate context in which to decide whether a woman's apprehension of imminent danger of death or great bodily harm was reasonable."); see also Mahoney, supra note 5, at 83-93 (explaining importance of jury understanding of "separation assault"); Maguigan, supra note 14, at 449 n.244 (advocating Mahoney's approach). Using my unpacked definitions in this context, I disagree with Victoria Nourse's characterization that Schneider relies upon the "notion of subjectivity." $C f$. Nourse, supra note 17, at 1278 (discussing Schneider's approach to self-defense).

324. The contextualization of reasonableness has always been accepted as part of the self-defense inquiry and became controversial only when pushed to the brink of "subjectivity" by proponents of the battered woman syndrome theory. See Nourse, supra note 17 , at 1289-90 \& nn.257-58 (citing century-old cases holding that the reasonableness of the defendant's beliefs must be measured from the perspective of a reasonable person in the defendant's situation).

325. Included within this standard is the issue of whether the level of force used by the defendant was reasonable. Even when an actor faces an imminent threat of unlawful force, the defensive force used must be proportionate to the threatened force. See 
reasonable person in the defendant's situation would have believed. Applied to a battered woman, the inquiry into the defendant's circumstances should include objective facts that the defendant knew about the batterer and the history of violence between the batterer and her, including any facts about failed attempts to escape the abuse. ${ }^{326}$ Knowledge of the batterer's history of abuse and his response to and other consequences of any of the defendant's previous attempts to leave would help the jury decide whether the defendant responded reasonably to a perceived threat by him. ${ }^{327}$

Jurors considering a claim of necessary self-defense under an objective contextualized standard of reasonableness would also be

LAFAVE, supra note 4, at 492-93; 2 ROBINSON, supra note 174, §131(c), at 77 . A standard of necessity for defensive force would contain the same requirement, since force is not necessary if it goes beyond the level of force sufficient for self-protection. See Rosen, supra note 142, at 20-21 (noting that disproportional force is not necessary force). This requirement is a commor issue in the literature regarding battered women who kill. A battered woman, for example, may be more inclined to use a weapon if her physical size, strength, and fighting skills place her at a disadvantage in a hand-to-hand battle with a man. See id. at 38; see also Faigman \& Wright, supra note 104, at 68-69 (criticizing the battered woman syndrome theory generally, but crediting its advocates for, among other things, drawing attention to the problematic application of the proportionality requirement to battered women who defend themselves); Krause, supra note 31, at 710-11 (advocating clemency for battered women who kill and noting proportionality as one aspect of traditional self-defense law that hinders the claims of such women); Maguigan, supra note 14, at 416-19 (noting that the majority rule does not prohibit women from using a weapon against an unarmed abuser per se, but instead focuses on the reasonableness of the defensive force); Elizabeth M. Schneider \& Susan B. Jordan, Representation of Women Who Defend Themselves in Response to Physical or Sexual Assault, 4 WOMEN's RTS. L. REP. 149, 157-58 (1978) (urging that juries be permitted to consider the relative size of the woman and her need to resort to a weapon when deciding self-defense claims); Schneider (1980), supra note 14, at 632 (noting that women are reluctint to defend themselves without a weapon).

326. For example, the Fifth Circuit in Willis, in rejecting the admission of expert testimony regarding battered woman syndrome in the duress context, recognized that a defendant should be permitted to show that her fear was well-grounded by presenting evidence not only of the immediate circumstances of the crime, but also of the defendant's past history with the person making the unlawful threat. United States v. Willis, 38 F.3d 170,177 n.8 (5th Cir. 1994).

327. This use of evidence regarding the history of prior abuse is suggested by both opponents and advocates of the battered woman syndrome. Schneider's work regarding the inequities caused when women are prevented from presenting a complete picture of the history of abuse has been especially important. See Schneider (1980), supra note 14, at 634-35. Ewing has argued that on the basis of her experience, a battered woman may be "better able to predict the likely degree of violence in any particular battering incident." EWING, supra note 149, at 55 (1987); see also People v. Torres, 488 N.Y.S.2d 358, 358 (N.Y. Sup. Ct. 1985) (evidence was relevant in part because the expert "would testify that a battered woman, through her extensive experience with prolonged physical abuse, learns to distinguish between varying degrees of danger and violence."). This use of evidence regarding a history of domestic violence is consistent with a depiction of battered women as more knowledgeable than average, as opposed to cognitively impaired. 
assisted by expert testimony demonstrating that battered women are not anomalies and, therefore, should not simply be dismissed as liars or inherently unreasonable in their belief that they could not safely escape the abusive relationship. Despite a reported decline in domestic violence in recent years ${ }^{328}$ nearly a quarter of all women report they have experienced violence in an intimate relationship during the course of their lives. ${ }^{329}$ Domestic violence is so common that intimate partners are the perpetrators of three-quarters of the rapes and physical assaults of women..$^{330}$

While the objective contextualization of the reasonableness standard permits consideration of the realities of the defendant's situation, it is not psychologically-individualized or otherwise "subjectified" as to include individual character traits that cause the defendant to have unreasonable beliefs or that themselves increase the likelihood of criminal conduct, despite situational forces. ${ }^{331}$ Jurors should not, for example, consider the evidence from the perspective of a "reasonable delusional paranoid schizophrenic" or "reasonable sociopath." Nor should they consider the evidence, as the battered woman syndrome theory suggests, from the perspective of a reasonable person who suffers from a condition that induces irrational beliefs about her ability to leave an abusive relationship or unreasonable perceptions about threats that are non-existent. The subjective version of contextualization advocated by battered woman

328. The Department of Justice reports that women were victims of domestic violence at a rate of 7.7 per 1000 in 1998 , down from 9.8 per 1000 in 1993. CALLIE MARIE RENNSON \& Sarah Welchans, U.S. Dep'T OF Justice, InTIMATE Partner VIOLENCE 3 (2000) (Sup. Doc. No. J29.13:IM 8).

329. Patricia Tuaden \& Nancy Thoennes, Nat'l institute of Justice \& CENTERS FOR DISEASE CONTROL AND PREVENTION, FUll REPORT OF THE PREVALENCE, INCIDENCE, AND CONSEQUENCES OF VIOLENCE AGAINST WOMEN: Findings fROM THE NATIONAL VIOLENCE AGAINST WOMEN SURVEY iv, 26 (2000) (Sup. Doc. No. J28.24/3:V 81/2) (reporting that $22.1 \%$ of surveyed women reported being physically assaulted by an intimate partner during their lifetime). Previous estimates of lifetime prevalence rates among women were as high as fifty percent. DEFENDING OUR LIVES, supra note 230 (reporting Federal Bureau of Investigations statistics).

330. Patricia TJaden \& NANCy Thoennes, NAT'L Institute of Justice \& Centers for Disease Control and PREVEntion, PREVAlenCe, INCIDENCE, AND CONSEQUENCES OF VIOLENCE AGaINST WOMEN: Findings fROM THE NATIONAL VIOLENCE AGAINST WOMEN SURVEY 12 (1998) (Sup. Doc. No. J28.24:V 81/6).

331. Mark Kelman, for example, notes that, in struggling to determine which of the defendant's traits to include in the profile of the hypothesized individual against whom the defendant's conduct is to be weighed, "[p]resumably, everyone tries to exclude from his vision of the typical man to whom the defendant is to be compared all the narrow-focused traits the defendant has that the criminal law is designed to alter-hot-headedness, hypersensitivity, proclivity to violence ...." Mark Kelman, Interpretive Construction in the Substantive Criminal Law, 33 STAN. L. REV. 591, 636-37 (1981). 
syndrome theorists is wholly inconsistent with the notion of selfdefense as a justification. ${ }^{332}$

Victoria Nourse has recently argued that the objective-subjective dichotomy is overstated and that the so-called objective status quo often relies on notions of subjectivity. ${ }^{333}$ She appears, however, to envision the second concept of the objective-subjective dichotomy, where the terminology describes whether the reasonableness standard is contextualized or non-contextualized. ${ }^{334}$ For example, as evidence that subjectivity has been a familiar notion in traditional criminal law, she cites early cases that instructed the jury to ask what a reasonable person- "in the position of the defendant, seeing what he saw, and knowing what he knew"-would have believed. ${ }^{335}$ As set forth above, the use of the objective-subjective terminology to describe the question of whether to contextualize the reasonableness standard does overstate the dichotomy, and "subjectivity" in this context (i.e., contextualizing the reasonableness standard) can be consistent with traditional notions of criminal law. ${ }^{336}$

Within a contextualized reasonableness standard, Nourse does not explicitly distinguish between the objective and subjective approaches. However, she does not appear to dispute that the psychologically-individualized standard of reasonableness that is advocated by battered woman syndrome theorists does not fall squarely within the traditional approach to contextualization. Indeed, she is able to argue that the battered woman syndrome theory is

332. See supra notes $135-45$ for discussion regarding the refusal to apply a psychologically-individualized concept of reasonableness to defendants other than battered women and the inconsistency of this concept of reasonableness with justification defenses. Subjective approaches to the contextualization of reasonableness can be found for excuse defenses. For example, the Model Penal Code's definition of voluntary manslaughter requires that reasonableness be determined "from the viewpoint of a person in the actor's situation under the circumstances as he believes them to be." MODEL PENAL CODE $\S 210.3(1)$ (b) (1985) (emphasis added). This latter component of the standard appears to require acceptance of the defendant's subjective beliefs about the surrounding factual circumstances, regardless of their reasonableness. A wholly objective, but contextualized, standard of reasonableness would adopt the viewpoint of a person in the actor's situation under the circumstances as he reasonably believes them to be. Unlike self-defense, provocation is an excuse, not a justification. Accordingly, the use of a subjective contextualized reasonableness standard does not undermine the philosophical underpinnings for the partial defense.

333. Nourse, supra note 17 , passim.

334. Nourse states that she uses " 'objectivity' ... in ways that are traditional in legal literature" and " subjectivity' ... [as] associated with its meaning in criminal law." Id. at $1240 \mathrm{nn} .22-23$.

335. Id. at 1289 \& n. 257 .

336. See supra notes 309-21. 
consistent with conventional criminal law only by first putting "claims of psychology and cycles aside." ${ }^{337}$ With those critical components of the battered woman syndrome theory set aside, Nourse then argues that the syndrome is consistent with standard self-defense notions, by informing jurors that women are not masochistic, can be highly attuned to the likelihood of danger, and face actual impediments to leaving. ${ }^{338}$ In other words, Nourse portrays the syndrome theory as conventional only after redefining the syndrome without its subjective components. That this redefinition was necessary demonstrates that the objective-subjective dichotomy retains significance when distinguishing the types of circumstances that should be considered in a contextualized approach to reasonableness.

\section{Application of the Standard}

Under the current approach to battered women and self-defense, the issues of whether a defendant can claim self-defense and present expert testimony to support the claim are determined more by the formal legal standards of the jurisdiction where she finds herself than by the individual facts of her case. Moreover, while the battered woman syndrome does nothing to help the hypothetical kidnap victim or other non-battered-woman defendants whose use of force may have been necessary in a non-confrontational situation, the theory does permit the expansion of the self-defense doctrine by battered women who should not be entitled to it. In contrast, treating battered women as rational actors and asking whether their objective circumstances supported a reasonable belief that force was necessary would permit self-defense when battered women reasonably believe their conduct is necessary, and prohibit it when they do not.

For example, consider a woman who has tried to protect herself from her husband's abuse. She has called the police, but the police do not arrest him. Or perhaps he has been arrested and prosecuted, only to serve a short jail sentence for misdemeanor charges and return to punish her for cooperating with police and prosecutors. She moves out when he is at work, but he tracks her down, assaults her, and tells her he will kill her if she ever leaves again. She believes that there is no safe way for her to leave the relationship and the only way to avoid further abuse is to kill her husband when he is not looking. Given these objective circumstances, a jury could find that the defendant's beliefs were reasonable.

337. Nourse, supra note 17 , at 1288.

338. Id. 
Consider, in contrast, a woman who is living at a battered women's shelter with her children in an attempt to leave her abusive husband. From a religious family, she has deep reservations about divorce, even in light of the physical abuse. Her children develop behavioral problems because of the disruption in their household. They are teased at school for being homeless. Their father threatens to seek sole custody of them because their mother has no realistic hope of securing the type of full-time employment necessary to provide a quality of life comparable to that which the children previously enjoyed. He does not, however, physically pursue his wife or threaten to harm her if she does not return. Depending on the value she places upon competing priorities, this hypothetical domestic violence victim might decide to return to her husband. ${ }^{339}$ She is not cognitively incapable of recognizing escape options; rather, she recognizes her escape options and makes what she decides is a rational decision not to pursue them. If she were subsequently threatened with imminent force by her husband, she should retain her rights to use self-defense, because her decision to return does not make her blameworthy for her husband's subsequent conduct. If she decides instead, however, to shoot her husband in his sleep, she would not be able to demonstrate that her actions were necessary to defend her own safety, and would therefore not be entitled to claim selfdefense. ${ }^{340}$

339. Courts have reasoned improperly that a battered woman who remains in an abusive relationship assumes the risk of further abuse. For example, in Commonwealth $v$. Watson, the trial court concluded that a battered woman was not imminently threatened when her boyfriend knocked her down, jumped on top of her, and grabbed her around the neck, in part because of the "long course of physical abuse" in the relationship. $431 \mathrm{~A} .2 \mathrm{~d}$ 949, 951 (Pa. 1981). The appellate court reversed, holding that the defendant did not consent to or assume the risk of further abuse by choosing to maintain the relationship. Id. at 951-52. As one commentator has explained:

Fault involves culpability, blameworthiness.... Certainly many women would leave at the first hint of physical abuse. Perhaps it can be said that one who does not choose this course has some responsibility for the ever-worsening situation. That does not, however, render culpable one who remains, whether for love or lack of other options. A difficult choice among many difficult choices, even one that, in hindsight, turns out to be wrong, is not necessarily a culpable choice.

Rosen, supra note 5, at 398-99 (1993); see also Nourse, supra note 17, at 1246-47 (discussing Watson).

340. Although this Article does not explore the possibility, the rational actor approach to self-defense is not inconsistent with the creation of a separate excuse that might apply to mitigate charges against battered women or other defendants who act under some type of psychological impairment. Stephen Morse, for example, has made the case for a "guilty but partially responsible" excusing condition based on diminished rationality. Stephen J. Morse, Excusing and the New Excuse Defenses: A Legal and Conceptual Review, in CRIME AND JUSTICE 329, 397-402 (Michael Tonry ed., 1998); see also Dressler, supra note 
Ironically, the prevailing theory of battered woman syndrome is most helpful to those women who I believe are least entitled to the assistance. By creating a replacement stereotype for jurors instead of merely correcting prevailing stereotypes, the syndrome evidence results in additional marginalization of battered women who do not fit the new syndrome stereotype. For example, Walker's paradigm omits women who have offered active resistance to the abuse by trying repeatedly to leave, only to be victimized further. The woman who repeatedly and actively resists abuse is the most justified in the subsequent use of deadly force, because she has explored alternatives to the use of force and has a basis for concluding that they are not viable. The omission of this woman from Walker's description of battered women is especially improper given that Walker's theory was developed primarily to support battered women's self-defense claims. $^{341}$

Although the rational actor approach would permit fewer nonconfrontational uses of force than the battered woman syndrome theory would, it would expand the scope of the justification where a forceful response was in fact required. Specifically, recognizing the use of force by battered women as justified, and not merely excused, would expand the ability of other actors to intervene against the batterer on the victim's behalf. Generally, an actor can use force to defend a third party, if the third party herself would be justified in using self-defense. ${ }^{342}$ Nevertheless, when a batterer is killed not by

9, at 275-81 (proposing that some battered women who kill in non-confrontational situations may be excused, but not justified); HERBERT FINGARETTE \& ANN Fingarette Hasse, Mental Disabilities and Criminal Responsibility 199-261 (1979) (arguing that mitigation applies to lessen criminality where there is "partial disability of the mind"). Similarly, some have suggested that domestic violence victims who kill their batterers under circumstances that do not meet standards of self-defense should be prosecuted only for manslaughter. See Shad, supra note 5, at 1175-77. Nor is it inconsistent with a claim of "imperfect" self-defense in jurisdictions that recognize this theory of mitigation. For example, the Model Penal Code permits negligent or reckless beliefs about the presence of a justification as a defense to crimes that require knowledge or purpose. MODEL PENAL CODE \$3.09(2) (1985); see also supra note 134 and accompanying text (describing the Model Penal Code's approach to self-defense).

341. The Sixth Circuit's decision in Seymour v. Walker, 224 F.3d 542 (6th Cir. 2000), cert. denied, 532 U.S. 989 (2001), illustrates the possibility that the battered woman syndrome theory has created a defense strategy only for those who fit the stereotype of passivity suggested by the syndrome. In this habeas case, the court rejected as speculative the defendant's argument that the use of battered woman syndrome evidence would have helped her claim of self-defense. Id. at 557. The court concluded that the evidence would not have helped the defendant, "especially in light of the facts that Seymour was no longer involved in the abusive relationship and that Seymour herself had acted violently toward Reams prior to the shooting." $I d$.

342. In jurisdictions that retain the "alter ego" rule, force used in defense of a third 
his victim, but by an intervening actor, the battered woman syndrome theory has not helped the intervenors' claims that they were defending a third party. ${ }^{343}$ Similarly, when battered women are accused of aiding, conspiring with, or soliciting the intervenors, courts have rejected the women's self-defense claims. ${ }^{344}$ The confinement of battered woman syndrome theory to cases in which the battered woman acts alone to kill her batterer is at least an implicit recognition that courts are using the syndrome theory to transform the justification of self-defense into an excuse based on the battered woman's alleged mental state. Because the battered woman syndrome theory seeks to excuse acts of defensive force by explaining the defendant's claimed good-faith but irrational perceptions, the theory provides no assistance when the force is inflicted not by the battered woman herself, but by a hit man or altruistic third party. An approach that treats defensive force against the batterer as justified, on the other hand, would apply whenever the use of force was necessary, regardless of whether it was the battered woman or a third party who inflicted it.

Extending defenses to situations in which the batterer is killed by an intervenor-actor and not the battered woman is admittedly one of the more troubling consequences of shifting the defense for battered

party is justified only if the third party himself actually would have been justified in using self-defense. DRESSLER, supra note 4, at 255; LAFAVE, supra note 4, at 502 . The majority modern view goes even further and permits the intervenor to use force whenever she reasonably believes the force to be justified in defense of a third party. See DRESSLER, supra note 4, at 256 (describing the "majority modern view"); LAFAVE, supra note 4, at 501, 503 (describing the "prevailing" and "preferable" rule as permitting defense of a third party when the intervenor reasonably believes force is necessary); see also MODEL PENAL CODE \& 3.05(1) (1985) (providing defense to intervenor who mistakenly, but reasonably, believes that force is necessary to defend third party).

343. See State v. Verrinder, 637 A.2d 1382, 1388-89 (Vt. 1993). In Verrinder, the defendant shot and killed the estranged, abusive husband of a woman he had befriended. Id. at 1388. The court permitted expert testimony regarding the battered woman syndrome to help the jury understand the battered woman's actions and, hence, to bolster her credibility as a witness. Id. at 1388-89. No attempt, however, was made to invoke the theory to assist the defendant's claim that he had acted not just in self-defense, but to defend his abused friend. $I d$.

344. See People v. Yaklich, 833 P.2d 758, 763 (Colo. Ct. App. 1991). In Yaklich, the defendant hired two men to kill her abusive husband. The court invoked two reasons for barring the defendant's self-defense claim. First, the court held that there was no imminent threat of violence. $I d$. at 763 . Second, the court assumed without analysis that the hired killers could not claim defense of others, and then held that it would be "poor public policy" for the defendant to escape liability while her hit men were convicted. Id.; see also State v. Anderson, 785 S.W.2d 596, 600 (Mo. Ct. App. 1990) (holding trial court did not err by excluding battered woman syndrome evidence in support of self-defense claim because defendant's agreement with a third party to kill her husband was wholly inconsistent with self-defense). 
women from an excuse based on battered woman syndrome theory to a true justification based on traditional self-defense principles. ${ }^{345}$ It is important to note, though, that the current rationale for prohibiting the use of battered woman syndrome theory in such "third party" cases is untenable. Battered woman syndrome theory is used currently to assist battered women's self-defense claims, not as a separate excuse defense or a theory of mental impairment. ${ }^{346}$ If the battered women invoking the theory were truly entitled to act on their own in self-defense, there would be no doctrinal basis to prohibit the use of force by a third party under those same circumstances. Even the most restrictive jurisdictions permit an actor to defend a third party under circumstances that would justify the third party's use of self-defense. ${ }^{347}$ In other words, the expansion of defenses to intervenors automatically follows from the expansion of self-defense rights. This relationship between self-defense and the defense of third parties demonstrates the importance of construing self-defense in accordance with the principles underlying the justification and restricting the defense to cases in which force reasonably appears necessary.

\section{Advantages of Viewing Battered Women as Rational Actors}

The battered woman syndrome lacks empirical support and has been used to apologize for conduct by battered women that is understandable and even rational when considered in light of the well-established, objective hurdles to leaving an abusive relationship. Viewing battered women as rational actors provides an alternative story about why battered women stay. When applied in the legal context of criminal defenses, the rational actor approach to understanding the conduct of battered women, when combined with elimination of the imminency requirement, reconciles the battered woman cases with traditional principles of self-defense by ensuring

345. See, e.g., Dressler, supra note 9, at 271 (noting discomfort with any theory that would permit a battered woman to use a contract killer against her abusive husband).

346. See Ibn-Tamas v. United States, 407 A.2d 626, 634 (D.C. 1979); State v. Pisciotta, 968 S.W.2d 185, 189 (Mo. App. 1998) (noting that statute permitting use of battered woman syndrome theory evidence does not make the syndrome a defense, but permits syndrome evidence to show the battered spouse's state of mind at the time of the offense in order to assist the jury in evaluating the self-defense claim); State v. Kelly, 478 A.2d 364, 377 (N.J. 1984).

347. DRESSLER, supra note 4, at 255; LAFAVE, supra note 4 , at 502 . The majority modern view goes even further and permits the intervenor to use force whenever she reasonably believes the force to be justified in defense of a third party. DRESSLER, supra note 4 , at 256 . 
that the defense is permitted if and only if a reasonable person would have believed that defensive force was necessary.

It is not obvious what effect this change would have on the absolute number of self-defense claims permitted by battered women. On the one hand, an objective contextualization of the reasonableness requirement would prevent some claims that might get to a jury under a subjective approach of contextualization, because the defendant would have to show that her beliefs were reasonable under the objective circumstances and could not rely upon claimed psychological peculiarities. ${ }^{348}$ On the other hand, elimination of the imminency requirement would permit force in nonconfrontational cases, as long as the defendant's conduct was reasonable under the objective circumstances. ${ }^{349}$ The recommended approach would lead to fewer successful self-defense claims only if the claims rejected using an objectively contextualized reasonableness requirement outnumber the "new" claims permitted in nonconfrontation cases. ${ }^{350}$ The empirical result would depend on how many of the defendants who would otherwise rely upon the psychological components of battered woman syndrome theory could demonstrate a reasonable belief that force was necessary by relying only on objective circumstances. Because current litigants tailor their defenses toward the battered woman syndrome theory, it is impossible to know what proportion of them could make a prima facie case that their conduct was objectively reasonable, without use of the syndrome theory. ${ }^{351}$ However, even if this approach results in fewer allowable self-defense claims, the approach is preferable to the battered woman syndrome theory, because the cases in which self-

348. See supra Section III.B.2.

349. Sè supra Section III.B.1.

350. Because most battered women who kill do so under confrontational circumstances, see Maguigan, supra note 14, at 382, 388-93, the "new" claims permitted by the elimination of the imminency requirement would probably not be a substantial proportion of the total number of successful claims.

351. In this context, it is noteworthy that many advocates for battered women believe that battered women's self-defense claims could prevail without the use of psychological theories, using what I call an objectively contextualized standard of reasonableness. See, e.g., SCHNEIDER (2000), supra note 14, at 124 (arguing that evidence of battering alone is not enough to justify self-defense, but the jury must be allowed to hear such evidence in order to understand the woman's apprehension of imminent death or serious bodily injury); Maguigan, supra note 14, at 449; Mahoney, supra note 5, at 83-93 (explaining importance of jury understanding of "separation assault"); Nourse, supra note 17, at 1288 (advocating "put[ting] claims of psychology and cycles aside"). 
defense is allowed would be more consistent with the principles of necessity and objective reasonableness that underlie self-defense. ${ }^{352}$

Moreover, the rational actor approach avoids many of the problems associated with the battered woman syndrome theory. First, the rational actor approach distinguishes among the victims of domestic violence and does not treat them as a homogenous group sharing a common set of characteristics. One criticism of the use of syndrome evidence generally is that, although it is offered to correct prevailing stereotypes regarding the affected group, it presents the danger of accomplishing more than a mere correction and might instead distort the jury's view in a different direction. ${ }^{353}$ Accordingly, it runs the risk of further disenfranchising those who do not fit the "new" stereotype described through the syndrome evidence. ${ }^{354}$ For example, some critics of Walker's work have observed that AfricanAmerican and Native American victims of domestic violence often do not conform to the image of learned helplessness that is conveyed by the battered woman syndrome. ${ }^{355}$ The rational actor approach does

352. See supra Section III.B.

353. See Mary Becker, The Passions of Battered Women: Cognitive Links Between Passion, Empathy, and Power, 8 WM. \& MARY J. WOMEN \& L. 1, 7-11 (2001) (describing cognitive biases based upon stereotypes that disadvantage battered women); Elaine Chiu, Confronting the Agency in Battered Mothers, 74 S. CAL. L. REV. 1223, 1249-50 (2001) (noting that the battered woman syndrome describes a "narrowly defined persona" that does not describe many battered women); Mosteller, supra note 9, at 464-65 (arguing generally that the risks of group character evidence vary according to the use of such evidence and that standards for admissibility should vary accordingly).

354. Donald A. DOWns, MORE THAN Victims: BatTered WOMEN, THE SYNDROME SOCIETY, AND THE LAW 166-68 (1996); Valli Kanuha, Domestic Violence, Racism, and the Battered Women's Movement in the United States, in FUTURE INTERVENTIONS WITH BATTERED WOMEN AND THEIR FAMILIES 34, 42-43 (Jeffrey L. Edleson \& Zvi C. Eisikovits eds., 1996) (noting that the battered woman's movement has tried to counter images of battered women as "bad" by portraying them instead as lacking agency and not fighting back, the "[e]verywoman, which, for mainstream America, is often equivalent to white, middle-class, moral, 'good' women"); Mary Ann Dutton, Understanding Women's Responses to Domestic Violence: A Redefinition of Battered Woman Syndrome, 21 HoFSTRA L. REV. 1191, 1195 (1995) ("[B]attered women's diverse psychological realities are not limited to one particular profile.").

355. Downs, supra note 354, at 167-68 (noting that battered women of color are more likely to fight back and that an explanation of battered women's conduct from a "solely victimized perspective" ignores the stories of such women); Linda L. Ammons, Mules, Madonnas, Babies, Bathwater, Racial Imagery and Stereotypes: The African-American Woman and the Battered Woman Syndrome, 1995 WIS. L. REV. 1003, 1068-80 (noting the discrepancy between the paradigmatic battered woman with learned helplessness and the empirical data and imagery associated with African-American women, and noting that the stereotype of learned helplessness could undercut the legitimate defenses possessed by African-American victims of domestic violence); Shelby A.D. Moore, Battered Woman Syndrome: Selling the Shadow to Support the Substance, 38 How. L.J. 297, 317-36 (1995) (summarizing empirical studies undermining the theories of learned helpless and the cycle 
not homogenize battered women and therefore does not marginalize women who do not conform to a predetermined vision of who a battered woman should be. By seeking to understand victims' conduct in light of their individual circumstances, the rational actor approach acknowledges diversity among domestic violence victims. ${ }^{356}$

A second advantage of the rational actor approach is its treatment of women as competent, rational decision makers, and the defensive use of force by battered women as justified, not merely excused. ${ }^{357}$ The battered women's syndrome theory depicts women as

theory of violence, and noting the negative effect of the battered woman syndrome upon African-American women who do not fit the paradigm conveyed by it).

356. There are important differences among batterers as well. Jacobson and Gottman describe a distinction between batterers who are "pit bulls" and those who are "cobras." JACOBSON \& GOTTMAN, supra note 229, at 36-39. Pit bulls confine their violence to family members, especially their wives. $I d$. at 38 . Other than family violence, they are not likely to engage in criminal conduct. Id. Cobras, however, demonstrate anti-social behavior in many contexts other than their intimate relationships. Id. at 36-37. Their study found that wives of pit bills leave their husbands more often and more quickly than do the wives of cobras, because cobras are more likely to inspire fear in their victims. Id. at 145-46. Even though pit bulls are safer to leave in the short run, however, they may be more dangerous to leave in the long run. Id. at 38-39. Whereas cobras quickly move on to new targets for their generally anti-social behavior, pit bulls are more likely to pursue their targets long after separation. $I d$. at 38-39,146-47.

357. Permitting a claim of self-defense where the actor is mistaken about the necessity of her conduct is not inconsistent with a theory of the defense as a justification, as long as the actor's mistake was objectively reasonable. As Kent Greenawalt has explained in the context of the necessity defense, when an actor reasonably believes that conduct is necessary, he is justified in taking the risk that he is mistaken, even if hindsight suggests that his reasonable belief was erroneous. Greenawalt, supra note 19, at 1908. Put another way, the question of whether conduct is justified should be viewed ex ante, rather than post hoc. Some theorists reject this categorization, arguing that mistaken, reasonable beliefs may constitute the basis for an excuse, but never for a justification. See Fletcher, supra note 286, at 566-67; Paul Robinson, Criminal Law Defenses: A Systematic Analysis, 82 Colum. L. REV. 199, 224, 242 (1982). Resolving the dispute about whether to draw a conceptual distinction between accurate and reasonably inaccurate defensive actors is not my priority. Without a crystal ball capable of depicting the present had the past been different, it will often be impossible after a person uses force based upon her reasonable beliefs to determine whether those beliefs were accurate or mistaken. Moreover, the law clearly treats these actors as equal by giving them both perfect defenses. See, e.g., MODEL PENAL CODE $\$ \$ 3.02,3.04$ (1985) (permitting self-defense and choice of evil defenses as long as the actor's beliefs are not reckless or negligent). More important to me is the certain distinction between reasonable and unreasonable mistaken force. Unlike true accuracy, which cannot feasibly be determined after force has been used, a juror can determine whether the defendant had a reasonable belief that her conduct was necessary at the time that she acted. The reasonable defensive actor stands on a higher legal and moral ground than the mistaken, unreasonable actor. It is for this reason that I argue that the law of self-defense must distinguish between battered women whose use of force is rational and battered women whose force is "reasonable" only when viewed through an psychologically-individualized, irrational standard of reasonableness. Viewing selfdefense as an excuse tends to blur this clear distinction, since excuses are more tolerant of 
irrational and lacking the ability to reason. Even the very term "syndrome" implicitly suggests that all battered women suffer from a psychological disability that prevents them from behaving "normally." 358 Legal advocates of battered women who kill may have viewed the syndrome theory's focus on the psyche as a tactical strength of the defense. Criminal law's traditional tendency is to punish conduct that flows from choice and to excuse conduct resulting from pathology. ${ }^{359}$ Retributivist notions of punishment view voluntary conduct as morally blameworthy and therefore more deserving of punishment, ${ }^{360}$ while utilitarianists view voluntary conduct as more subject to deterrence than involuntary conduct. ${ }^{361}$

psychological idiosyncrasies. See Finkelstein, supra note 5, at 627-31. Finkelstein would restrict justification to self-defense cases where the force was actually necessary, and then permit an excuse whenever the defendant reasonably believe that her use of force was lawful. Id. Finkelstein, however, would use a completely subjective view of reasonableness, thereby failing to distinguish between rational and irrational actors. $I d$. at 630-31; see also Rosen, supra note 142, at 45-56 (advocating the creation of a self-defense excuse for battered women).

358. See, e.g., Dressler, supra note 9, at 268 (noting that the term "syndrome" connotes an abnormality). Some have criticized Walker's work because of its tendency toward stereotyping, even though they generally favor Walker's accomplishments on behalf of battered women. Mahoney, for example, justifiably credits Walker for her summary of battered women's experiences and her attempts to bring women's stories into court through expert testimony. Mahoney, supra note 5, at 42 . She argues, however, that the emphasis upon helplessness in the psychology of individual women risks contributing to stereotypes. Id. at 41-43.

359. See, e.g., FLETCHER, supra note 143, §10.3.2 (distinguishing the excusable involuntary act (e.g., an act under duress) from an act where there is no wrongdoing at all (e.g., the actor stabbing his neighbor while having a seizure)); JEROME HALL, GENERAL PRINCIPLES OF CRIMINAL LAW 455-60 (2d ed. 1960) (citing the clash of elementary philosophical perspectives as the dividing line between psychology and criminal responsibility); Herbert L. PACKer, THE Limits OF THE CRIMINAL SANCTION 74-75 (1968); Larry Alexander, A Unified Excuse of Preemptive Self-Protection, 74 NOTRE DAME L. REV. 1475, 1487 (1999) (noting that "duress differs from other excuses recognized by criminal law, such as insanity, intoxication and infancy"); Kelman, supra note 331, at 597-98,642 (describing blameworth:ness as deriving from the intentionalist, as opposed to determinist model); Stephen J. liorse, Rationality and Responsibility, $74 \mathrm{~S}$. CAL. L. REV. 251, 256-57 (2000) (describing compelled, coerced, or involuntary conduct as excusable).

360. For presentations of a retributivist view of punishment, see generally IMMANUEL Kant, The Metaphysical Elements of Justice (J. Ladd tr., 1965); Michael S. MOORE, LAW AND PSYCHIATRY: RETHINKING THE RELATIONSHIP 238, 238-45 (1984); Michael S. MoORe, Placing Blame (1997); David Dolinko, Three Mistakes of Retributivism, 39 UCLA L. REV. 1623, 1632-33 (1992); Jean Hampton, Correcting Harms versus Righting Wrongs: The Goal of Retribution, 39 UCLA L. REV. 1659 (1992); H.J. McCloskey, A Non-Utilitarian Approach to Punishment, 8 INQUIRY 249 (1965); and Jeffrie G. Murphy, Retributivism, Moral Education, and the Liberal State, CRIM. JUST. ETHICS, Winter/Spring 1985, at 3.

361. For presentations of a utilitarian view of punishment, see generally JEREMY Bentham, The Theory of Legislation 322-38 (ed. 1931); John Stuart Mill, 
Accordingly, advocates for battered women may have concluded that their best defense was to depict their clients not as fully autonomous and responsible actors, but as suffering from an abnormality rendering them incompetent or without the capacity to make voluntary choices.

However, as a result of the emphasis upon battered woman syndrome, advocates for battered women who kill have transformed an explanation of what is supposed to be self-defense into something resembling a mental defect defense. ${ }^{362}$ Courts that sign off on the theory depict the battered woman as a zombie, wholly lacking the ability to behave and think rationally. ${ }^{363}$ At least one jurisdiction has gone so far as to treat battered woman syndrome procedurally like the defense of insanity and to require the defendant to undergo examination by a court-appointed psychiatrist. ${ }^{364}$

UTILITARIANISM (1863); and FrankLIN E. ZimRING \& GORDON J. HAwKINS, DETERRENCE (1973); Louis Michael Seidman, Soldiers, Martyrs, and Criminals: Utilitarian Theory and the Problem of Crime Control, 94 YALE L.J. 315, 319-34 (1984).

362. See, e.g., United States v. Willis, 38 F.3d 170, 175 (5th Cir. 1994) (referring to battered woman syndrome as a "psychological condition"); United States v. Gaviria, 804 F. Supp. 476, 479-80 (E.D.N.Y. 1992) (downward departure because defendant was susceptible to "dependence, domination, and victimization"); State v. Mott, 931 P.2d 1046, 1054-55 (Ariz. 1997) (affirming trial court's exclusion of evidence of the battered woman syndrome to support defendant's claim of diminished capacity for failing to take child to hospital, because state law prohibited evidence of mental disease or defect, not constituting legal insanity, for the purpose of negating the required mens rea); State v. Hundley, 693 P.2d 475, 479 (Kan. 1985) ("Battered women are terror-stricken people whose mental state is distorted and bears a marked resemblance to that of a hostage or prisoner of war."); State v. Copeland, 928 S.W.2d 828, 838 (Mo. 1996) (affirming exclusion of expert testimony regarding battered woman syndrome, in part because defendant had not filed requisite notice for evidence of mental disease or defect); Cox v. State, 843 S.W.2d 750, 754-55 (Tex. Crim. App. 1992) (affirming district court's exclusion of evidence because woman testified that husband could not have forced her to commit the actual murder, just to conspire, showing she was capable of exerting herself); $c f$. United States v. Johnson, 956 F.2d 894, 899 (9th Cir. 1992) ("Battered woman syndrome is not a mental disease or defect; rather, battered woman syndrome is a post-traumatic stress disorder."). But see United States v. Marenghi, 893 F. Supp. 85, 92 n.10 (D. Me. 1995) (declining to decide whether battered woman syndrome is properly characterized as a mental defect); United States v. Bell, 855 F. Supp. 239, 240 (N.D. Ill. 1994) (stating that battered woman syndrome is a defense unrelated to a defendant's mental capacity).

363. For example, one court described the defendant's characterization of the battered woman as "psychologically vulnerable and emotionally incapable of extracting themselves from the victim's role into which they have fallen." Lumpkin v. Ray, 977 F.2d 508, 509 (10th Cir. 1992). Similarly, as described by another court, battered women "easily fall prey to their mates' coercion and intimidation and have no means of resisting demands to do things against their will and interest." People v. Smith, 608 N.E.2d 1259, 1262 (Ill. App. Ct. 1993).

364. MO. REV. STAT. $\S 563.033$ (Supp. 1992) (equating the use of battered woman syndrome procedurally with an insanity plea and requiring that defendant submit to examination by a court-appointed psychiatrist). As one commentator observed: 
Although undoubtedly with the best of intentions, the advocates of battered woman syndrome have created a defense in which battered women are left attempting to excuse and apologize for their fears, depriving them of the claim of objective justification that other self-defending actors enjoy. In this respect, the rampant use of the battered woman syndrome defense and its frequent characterization as an incapacity undermines what Elizabeth Schneider has identified as the original goal of feminist lawmaking - "to be included within the traditional framework of the criminal law in order to guarantee their equal rights to trial." 365 An alternative approach that treats battered women as rational actors operating under their individual circumstances permits battered women not to apologize for seemingly irrational conduct, but instead to explain to the jury the reasonableness of their behavior and to argue that their conduct was justified..$^{366}$

\footnotetext{
If [a woman's inability to leave an abusive relationship] is seen as her pathology, the law may offer her some redress. But ... the battered woman's perceptions of the constraints on her decisionmaking may not be pathological at all but grounded in reality. Paradoxically, this eliminates the chance of legal remedy by transforming the inquiry from her mental incapacity to her circumstantial constraints. Because these constraints are not cognizable as either her incompetence or (except under very extreme conditions) duress, the law presumes that she is a competent individual whose actions and decisions are a result of her own free will. Battered women are perceived by law to be either pathological victims who are out of contact with reality, and therefore entitled to some remedy, or autonomous individuals capable of making choices in their lives (presumably, the choice to leave) and therefore responsible for those choices.
}

Susan Stefan, Silencing the Different Voice: Competence, Feminist Theory and Law, $47 \mathrm{U}$. MIAMI L. REV. 763, 792-93 (1993) (emphasis added); see also Schneider (1980), supra note 14, at 636 (arguing that judges often exclude evidence of an individual woman's perceptions and circumstances and juries are more likely to excuse a woman's actions on grounds of incapacity than they are to find them justified under a claim of self-defense).

365. SCHNEIDER (2000), supra note 14, at 114. Although Schneider believes that the original goal of the litigation on behalf of battered women who kill was to expand defense options in order to "equalize women's rights to trial and afford women equal opportunity to present an effective defense," she acknowledges that the current use and common understanding of the battered woman syndrome theory are "premised on a fundamental misunderstanding of the original arguments." Id.

366. Phyllis Crocker also has recognized the importance of preserving the notion of self-defense as a justification, and not an excuse, in the context of the battered woman. Crocker, supra note 216, at 130-31. As an excuse, self-defense would imply that the battered woman's response to abuse was "idiosyncratically emotional," thereby suggesting that the woman's assessment of the threat was irrational and that the legal system is simply compensating her for mental and physical weaknesses. Id. at 131. Crocker agrees that the doctrine must continue to operate as a justification when applied to battered women. Id. As a justification, the doctrine validates the worthiness of the battered woman's life, finding it worthy of defense, and compelling recognition of a woman's capacity for rational thought. Id. 
A third potential advantage of the rational actor approach to understanding the decisions of battered women is that it may actually provide more practical assistance to domestic violence victims than the prevailing syndrome explanation. A results-oriented advocate for battered women might be inclined to reject the rational actor approach in favor of the prevailing battered woman syndrome theory, regardless of its analytic and empirical flaws, if doing so would be to the general advantage of domestic violence victims. Even from a completely results-orientated perspective, however, the rational actor approach may be favorable to the syndrome theory. As an initial matter, it is not obvious that replacement of the battered woman syndrome theory with the rational actor approach would lead to more convictions of battered women who use defensive force. Although claims of mental defect were the favored defense du jour two decades ago when the battered woman syndrome was first postulated, potential jurors brought up on Court TV in a post-Menendez brothers environment are justifiably skeptical of "abuse excuses" and groupbased evidence generally. ${ }^{367}$ At the same time, potential jurors generally have a better understanding of the dynamics and frequency of domestic violence than they had twenty years ago. ${ }^{368}$ Even more promising is the fact that younger people demonstrate the greatest knowledge about domestic violence, ${ }^{369}$ suggesting that future generations of juries will be even more understanding of the factors that restrict safe alternatives to an abusive relationship and therefore contribute to a battered woman's decision to remain with her

367. Inspired by psychology-dependent defenses invoked by the Menendez brothers, Lorena Bobbitt, Colin Ferguson, and others, Alan Dershowitz coined the now familiar phrase "abuse excuse" to describe a "legal tactic by which criminal defendants claim a history of abuse as an excuse for violent retaliation." DERSHOwITZ, supra note 149, at 3, 45; see also WILSON, supra note 149, 56-58, $62-66$ (raising similar concerns about criminal defenses based upon a defendant's prior abuse).

368. A 1987 study of the popular myths about battered women among lay people found that $63.7 \%$ of people surveyed believed that a battered wife could simply leave her husband if she was afraid of him, and $41.8 \%$ thought the wife was a masochist if she did not leave and the abuse continued. Charles Patrick Ewing \& Moss Aubrey, Battered Women and Public Opinion: Some Realities About the Myths, 2 J. FAM. VIOLENCE 257, 261 tbl.1 (1987). Subsequent studies have found the general public to be more knowledgeable. See Morse, supra note 359, at 314 (summarizing research after the Ewing and Aubrey study).

369. One survey found that subjects between eighteen and thirty-one years of age were the most knowledgeable about battered women, while the oldest group of subjects, between forty-five and seventy-nine years old, was the least knowledgeable. Mary Dodge \& Edith Greene, Juror and Expert Conceptions of Battered Women, 6 VIOLENCE \& VICTIMS 271, 278-81 (1991). 
batterer. Accordingly, once the claim gets to a jury, ${ }^{370}$ there is every reason to believe that, strategically, a straight claim of justification is more likely to succeed, and a claim of a psychological syndrome is more likely to be rejected, now than two decades ago.

Even if the rational actor approach may lead to more convictions of battered women who use defensive force, explaining the conduct of battered women through an examination of individualized circumstances may be more advantageous than the battered woman syndrome to the general population of battered women. In addition to the symbolic injury inflicted upon battered women by depicting them as homogenous, abnormal, and irrational, ${ }^{371}$ the prevailing characterization of battered women may adversely affect domestic violence victims by failing adequately to explain the realities of their lives to others who need to understand them.

The following anecdote describes one possible negative consequence of the prevailing syndrome explanation for women remaining in abusive relationships. The law enforcement community generally is unsympathetic to claims of psychological incapacity and tends to view individuals as autonomous actors responsible for their conduct. As a Deputy District Attorney, I helped teach an in-service training relating to domestic violence. Before I got to my portion of the class, I watched the officers' eyes roll as a social worker invoked the psychological concepts of learned helplessness and the cycle of violence to explain the uncooperativeness of domestic violence victims. By the time I got to my portion, covering the state's mandatory arrest laws and the investigation and prosecution of cases without the victim's participation, the officers did little to mask their hostility toward my topic. Rather than build upon the introduction provided by the social worker, I talked about battered women not as psychologically impaired but as rational actors with their own individualized reasons for remaining in the relationship. Acknowledging the officers' frustrations with responding repeatedly to the same address, with no resulting convictions, I offered as a solution some advice on how to investigate cases to facilitate

370. See supra notes $350-51$ for a discussion of the difficulties in assessing whether the recommended approach would result in fewer self-defense claims getting to a jury.

371. Because the battered woman syndrome theory depicts women as incapable of rational self-control, Anne Coughlin has written that it is "profoundly anti-feminist." Coughlin, supra note 149 , at 6 . Beyond the symbolic injury that this depiction inflicts upon women's autonomy, Coughlin fears that the battered woman syndrome theory "exposes women to forms of interference against which men are safe" by denying to women the "same capacity for self-governance that is attributed to men." Id. 
prosecution of the offender without the victim's testimony. I used sample cases, explaining the history of violence in the relationship and the lack of viable options that the women had outside the relationship. Recognizing similar facts in cases they had worked to no avail, the officers became a more receptive audience and began to demonstrate the empathy for victims that they held as individuals, if not as a culture. By failing to treat domestic violence victims as the rational actors that they are, the attempt to indoctrinate the law enforcement community and the public with the battered woman syndrome theory may undermine the goal of improving police and private responses to domestic violence situations. ${ }^{372}$ Even from a completely results-oriented perspective, therefore, it is conceivable that abandoning the battered woman syndrome theory in favor of the rational actor approach would benefit domestic violence victims generally.

\section{Battered Women as Rational Actors and the Defense of Duress}

Although the battered woman syndrome theory is a better "fit" with the defense of duress than claims of self-defense, the reality is that battered women who use force against their batterers have had more success invoking the theory than those who committed crimes against third parties at their batterers' command. Viewing battered women as rational actors responding to their individual realities explains the current disparity between self-defense cases and duress cases in this context. Unlike the battered woman syndrome theory, which would appear to apply in the duress context at least as readily as in the self-defense cases, the objective reasonableness of a battered woman's decision to act is markedly different in the two contexts. Although the realities of a woman's situation may make defensive force against her batterer necessary, even in the absence of an imminent threat by him, those same realities do not warrant a departure from the traditional confines of the duress defense when a domestic violence victim is accused of committing crimes in cooperation with her batterer.

Normative values of moral blame pervade the doctrine of duress. As Professor Dressler explains:

372. For a general discussion of attempts to improve police intervention in domestic violence, and the common hurdles to those efforts, see PAMELA J. JENKINS \& BARBARA Palmer Davidson, StopPing DOMESTIC Violence: How a COMMUNity CAN PREVENT SPOUSAL ABUSE 13-39 (2001). 
It is too simplistic to treat coerced actors as victims rather than as victimizers, for they are both. They are victims of a coercive threat; but they are also victimizers because they have chosen to protect themselves at another innocent person's expense. Indeed, most victimizers are also victims. Even the worst criminals are victims of a poor genetic pool, of an unhealthy environment, or of both. No one acts free of inherited and environmental constraints. Yet, people are not excused for their wrongdoing simply because their criminal activities are causally related to some factor beyond their control. ${ }^{373}$

The duress doctrine requires more than sympathy or difficult circumstances to excuse. Duress excuses only when a person lacked any reasonable opportunity to avoid acting unlawfully, not simply because it was more difficult for her than for others to comply with the law. ${ }^{374}$ Viewed from this perspective, the failure of most duress claims by battered women is a further demonstration that the duress defense is not available simply because the empirical mean of all human beings would have succumbed to the coercion. Stanley Milgram's infamous obedience studies demonstrated that the statistically average person will inflict grave injury upon other individuals, even in the absence of any direct threat of harm to himself, simply because he is commanded to do so by an authority figure. ${ }^{375}$ The law requires more.

Joshua Dressler has observed that the defense of duress involves a strong normative component: the defense isn't one of "I'm only human," because the question is not whether most people would have succumbed to the duress. ${ }^{376}$ The doctrine requires jurors instead to determine what they as representatives of a lawful society expect from humanity. ${ }^{377}$ Although the model to whom the defendant is compared is not saintly, she is also not a merely average person. ${ }^{378}$ Instead, jurors are asked to compare the defendant to an imaginary person who encompasses the moral fortitude that we expect as a society. ${ }^{379}$ Because of the moral reticence triggered by the duress

373. Dressler, supra note 170, at 1361.

374. Id. at 1365.

375. STANLEY MilgRAM, OBEDIENCE TO AUTHORITY 34-40 (1974).

376. Dressler, supra note 170 , at 1363-67.

377. Id. at 1366.

378. See id. at 1367 (noting that the issue in a duress claim is whether "we could fairly expect a person of nonsaintly moral strength to resist" the actor's conduct).

379. The Model Penal Code's version of the duress doctrine emphasizes moral fortitude by requiring jurors to compare the defendant to a person of reasonable firmness, and not just simply to a reasonable person. MODEL PENAL CODE $\$ 2.09(1)$ (1985). A 
defense, the objective standard applied in the duress context is more normative and less empirical than the standard of reasonableness that should apply in the self-defense context.

Once battered women are viewed as rational actors and the nature of the duress defense is understood, the reluctance to expand the defense of duress to accommodate the duress claims of battered women is no longer perplexing. In the self-defense context, we have been justifiably disinclined to punish women who harm their batterers. In limited situations, this use of force may be the only option to escape a situation that the batterer created with his own abuse. When the use of defensive force is necessary even in the absence of immediate confrontation, elimination of the imminency requirement is warranted by the fact that the abuser and ultimate victim is responsible for depriving the defendant of a fair opportunity to protect her own safety without taking his life.

The underlying notions of rationality and blameworthiness are entirely different, however, when a woman engages in criminal conduct to appease her batterer. To be clear, if a battered woman is threatened with imminent harm lest she facilitate her batterer's crimes, she enjoys an excuse under the traditional confines of the duress doctrine, even though she remained in the abusive relationship voluntarily up to that instance. However, when viewed as rational actors, battered women should not be excused when they choose in the absence of an imminent threat to commit crimes against innocent third parties rather than confront the difficulties of leaving an abusive relationship.

Whereas a woman's decision to use force against her batterer in the absence of an imminent threat may be reasonable under certain circumstances, it is difficult to imagine any scenario in which crimes against third parties would be necessary in the absence of an imminent threat. A clear distinction between a battered woman who acts in self-defense and a battered woman who facilitates the crimes

higher standard of objectivity in the defense context reflects the moral ambivalence that has historically surrounded the defense. A more rigorous standard reflects competing feelings of sympathy toward the coerced actor and disgust with her inability to refrain from unjustified conduct. The law's recognition of the moral reticence to excuse the placing of one's own safety above an innocent's dates back at least to the famous case against Dudley and Stephens, who killed and cannibalized a cabin boy while stranded on a boat in a storm. Although it was beyond question that the defendants' conduct was motivated only by the desire to survive, Lord Coleridge was skeptical of the requested exception to the rule of law: "There is no safe path for judges to tread but to ascertain the law to the best of their ability and to declare it according to their judgment ..." The Queen v. Dudley \& Stephens, 14 Q.B.D. 273, 288 (1884). 
of her batterer is the difference between available resources. In the self-defense context, the primary argument for eliminating the requirement of imminency as a proxy for necessity is the conceivability that there are battered women whose options to the use of force are so limited that they are indistinguishable from Robinson's hypothetical kidnap victim. We find it credible that even the most progressive, well-intending criminal justice system is still illequipped to protect these women. Domestic violence prosecutions must focus upon individual assault incidents, as opposed to a lifetime of abuse, so the defendant can create reasonable doubt about his liability on a single occasion. Even if he is convicted, his conviction and resulting sentence does not reflect the full scope of his abuse. The current system also does little to protect domestic violence victims while their batterers are free on bail or after their batterers have served what usually are short sentences.

The battered woman who is asked to be an accomplice to a crime, however, stands in a markedly different position. The traditionally weak police and prosecutorial response to domestic violence does not determine the police response to her potential complaints regarding the other criminal conduct her batterer has committed. The criminal justice system may be either incapable of and/or unwilling to respond to the self-protection needs of the perpetually threatened battered woman. It would, however, respond were she able to deliver inculpatory evidence against her batterer for other crimes.

An additional reason not to expand the duress defense to actors who succumb to non-imminent coercion stems from the common law distinction between coercion exerted by another person and coercion that results from the defendant's natural state or societal circumstances. At common law, and in some jurisdictions today, the defense of duress required pressure from other people, as opposed to pressure from physical, natural causes. ${ }^{380}$ When a battered woman engages in unlawful conduct not because she faces an imminent threat of unlawful force, but because of remote circumstances surrounding a violent relationship, her claim becomes less about the coercion exerted by a bad actor and more about the poor circumstances of her life. ${ }^{381}$ In other words, what she seeks to avoid by engaging in the

380. This distinction is implicit in the Model Penal Code, which requires that the defendant's conduct be coerced by the use of or threat to use "unlawful force against his person or the person of another." MODEL PENAL CODE $\S 2.09(1)$ (1985).

381. From this perspective, the battered woman who participates in crimes with her batterer when there is no imminent threat from him is comparable to a gang member who 
criminal activity is not imminent punishment from her batterer, but the difficult circumstances she would encounter if she left the battering relationship. Viewed this way, her situation is more analogous to a defendant who, facing poverty, steals food to avoid eventual starvation, than to a defendant who robs a bank because a bad actor holds a gun to her head and orders her to do so. Many have opined whether and why the law should penalize the former and excuse the latter. ${ }^{382}$ The distinction appears to reflect a need to place blame on culpable actors for undesired results: The law excuses the defendant if there is another bad actor to point to, but cannot when the alternative is to blame nature or, even worse, ourselves by blaming society. ${ }^{383}$ This need to place blame on either the defendant or some other culpable actor assists battered women in the selfdefense context, in which the victim is the same bad actor who created the undesirable circumstances that limited the defendant's viable

commits crimes with his fellow gang members and then claims duress. The prevailing view is that the gang member is responsible for his decision to join a gang and therefore cannot show that he did not recklessly place himself in a situation in which he would be subject to duress. See MODEL PENAL CODE § 2.09(3) (1985) (providing that the affirmative defense of duress is not applicable when the defendant recklessly placed himself in a situation in which it was probable that he would be subject to duress). This explanation, however, ignores the fact that many youths join gangs because their societal realities dictate this association as a viable course of self protection in the neighborhood, which then eventually leads to criminal activity. Viewed in that context, the gang member (although less sympathetic politically) is in a similar situation to a battered woman who has reasons for remaining in an abusive relationship that also involves the commission of crimes. With respect to both examples, I argue that we do not excuse because the real reasons for the conduct is the defendant's choice to maintain the association rather than to accept the risks of the societal factors that make escape options difficult. My normative conclusions about battered women who help their abusers commit crimes are similar to observations that Dressler has made about "coerced" gang members. See Dressler, supra note 170, at 1382-83.

382. E.g., MODEL PENAL CODE $\$ 2.09 \mathrm{cmt}$. (1985) (retaining common law distinction in part on the pragmatic basis that criminal law can prosecute human threats but not natural ones); HALL, supra note 357, at 447 (arguing that coercion due to natural forces might be a defense to homicide, but not coercion due to human actors, because the human actor may change his mind at any instant); Herbert Fingarette, Victimization: $A$ Legalist Analysis of Coercion, Deception, Undue Influence, and Excusable Prison Escape, 42 WASH. \& LEE L. REV. 65, 84 n.54, 106, 109 (1985) (noting that a human threat is an element of duress because the coercive threat must be wrongful). Several of the most influential criminal law scholars of the day have concluded that the distinction in the duress context between human and natural threats should be abolished. FLETCHER, supra note 143, at 834 (questioning the distinction and arguing that " $[\mathrm{t}]$ he question should not be whether the actor can be fairly expected to resist human threats, but whether he can fairly expect to abstain from an act that seems required under the circumstances"); KENT GREENAWALT, CONFLICTS OF LAW AND MORALITY 289 (1987); Dressler, supra note 170 , at $1374-76$ (concluding that the duress defense should not be limited to human threats); Kadish, supra note 170 , at 273-74.

383. MODEL PENAL CODE, $\S 2.09 \mathrm{cmt}$. (1985). 
options. Whatever the basis for the distinction, the traditional limitation of the duress defense to person-imposed (and not circumstance-imposed) pressure weighs against the grant of special consideration to the battered woman who helps her batterer commit crimes when she faces no imminent threat. ${ }^{384}$

Utilitarian concerns provide a final and clear distinction between battered women who, faced with a non-imminent threat, act in selfdefense and those who act against third parties. The duress paradigm generally envisions a one-time crime or perhaps even a crime spree in which the defendant engages in the coerced conduct only so long as necessary to escape the threat eventually. Extension of the defense to a battered woman who faces no imminent threat, but who instead is trapped indefinitely in an abusive relationship, would provide permanent, standing license for the defendant to facilitate her batterer's crimes. Put another way, the innocent third parties are harmed to no avail. Even after the crime is committed, the defendant stands in precisely the same circumstances. This is an obvious distinction from the facts in a self-defense case, where the battered woman's use of force against her batterer is argued to be the necessary solution to an otherwise inescapable situation. ${ }^{385}$

When Judith Ann Neelley has a gun in her hand, she has viable choices. At the very least, she can shoot her husband rather than the innocent third party he has chosen to victimize. The battered woman syndrome theory does not reflect this reality and would exculpate the perpetually threatened battered woman who continually victimizes others. When battered women are viewed as rational actors, however, the inability of battered women to expand the traditional defense of duress is the predictable and preferred result.

384. When the threat is viewed as one of circumstance and not one by a human actor, the defense of necessity potentially applies. However, the battered woman who commits crimes against a third party in the absence of an imminent threat would be unlikely to be able to claim necessity, either. Necessity requires, among either elements, a clear and imminent threat of harm, a direct causal relationship between the crime committed and the harm avoided, that the harm avoided be greater than the harm imposed, and the absence of any reasonable legal alternatives to the crime. See DRESSLER, supra note 4, at 287-89.

385. Paul Robinson has recognized that the balancing of harms is less strict when a culpable party bears the harm of the conduct at issue, and defensive justifications often permit an actor to cause greater harm against culpable parties than he avoids by doing so. 2 ROBINSON, supra note $174, \S 131$ (a), at 69-73. The more stringent balancing of harms that applies when innocent parties bear the costs weighs even heavier against the coerced actor when her defensive conduct gets her no closer to a threat-free state of existence. 


\section{CONCLUSION}

To return to the three hypothetical defendants used to introduce this Article ${ }^{386}$ the law should recognize Judy as the most justified defensive actor, because, unlike Edith or Anthony, she resorted to deadly force only after several futile nonviolent attempts to avoid future violence.

Viewed as a utilitarian theory of justification, self-defense permits a non-aggressor to kill an aggressor because if someone must die, better it be the dangerous aggressor than the innocent nonaggressor. ${ }^{387}$ Judy's circumstances provide the best fit with this theory of the defense, because the eventual death of one of the actors appears most inevitable in her scenario. Anthony has a safe avenue of retreat, and Edith has no reason to believe that her husband is going to pursue and kill her. ${ }^{388}$

As a non-utilitarian, moral theory of justification, the right to defensive force exists because an aggressor enjoys lesser rights. ${ }^{389}$ Some say an aggressor forfeits his right to live, ${ }^{390}$ or, less extremely, has a life with less value than the safety of an innocent person. ${ }^{391}$ Others view self-defense as punishment inflicted by injured private parties who act as the state's proxy to "avoid the injustice of suffering unsanctioned crime." ${ }^{\prime 392}$ Again, Judy appears to be more justified. Among the three decedents, her husband inflicted the greatest social harm, not only beating his wife but also letting her know that she could do nothing to avoid future assaults.

Although Judy's use of force is at least as justified as Anthony's from both utilitarian and retributive perspectives, the current regime

386. See supra notes $2-4$, and the accompanying text for the examples of Anthony, Edith, and Judy, based upon the defendants in Idrogo v. People, 818 P.2d 752 (Colo. 1991), Buhrle v. State, 627 P.2d 1374 (Wyo. 1981), and State v. Norman, 324 N.C. 253, 378 S.E.2d 8 (1989), respectively.

387. Sanford H. Kadish, Respect for Life and Regard for Rights in the Criminal Law, 64 CAL. L. REV. 871, 882 (1976) (discussing, but ultimately rejecting, a utilitarian justification of self-defense).

388. See supra notes 293-304 and accompanying text for a discussion of the duty to retreat.

389. See generally DRESSLER, supra note 4, at 234 (discussing non-utilitarian views of self-defense as a justification).

390. E.g., A. J. Ashworth, Self-Defence and the Right to Life, 34 CAMBRIDGE L.J. 282, 283 (1975) (" $[\mathrm{A}] \mathrm{n}$ attacker may, by threatening the life of another, forfeit his own right to life.").

391. DRESSLER, supra note 4, at 234.

392. George P. Fletcher, Punishment and Self-Defense, 8 LAW \& PHIL. 201, 215 (1989); see also GEORGE P. FleTCHER, A CRIME OF SELF-DefENSE: BERNHARd GOETZ AND THE LAW ON TRIAL 27-28 (1988) (discussing the tendency to view self-defense as a form of just punishment). 
prohibits her from making a straight claim of justification because she did not face an imminent threat at the time she acted. Rather, her best shot at avoiding conviction would be to rely upon the battered woman syndrome theory, a theory which purports to apply to any battered woman, even Edith, who, by any objective notion of reasonableness, lacks a reasonable belief that her use of force was necessary. At the same time, someone like Anthony can claim justification, because he, unlike Judy, faced an imminent threat, albeit one from which he could have safely retreated. In short, the current regime of self-defense is stingy toward the most justified of our three hypothetical actors. It forces her to depict herself as syndromatic in order to invoke the defense, leaving her in the same footing as an unjustified actor like Edith, while it generously permits Anthony to claim justification for force that could safely have been avoided.

The better approach would be to reject what has essentially been a modification of self-defense norms through the use of syndrome evidence, and to ask instead whether the defendant had a reasonable belief that her force was necessary. Evidence of the objective factors contributing to a battered woman's decision to stay within an abusive relationship would assist jurors in understanding the circumstances leading up to a woman's alleged crime against her batterer. Moreover, knowledge of the batterer's history of abuse would help the jury determine whether a woman responded reasonably to a perceived threat by him and whether her use of force was necessary. Yet few courts or commentators have relied on the realities of individual women's lives to explain the reasonableness of their conduct. Instead, the psychological components of the battered woman syndrome theory have provided the argument of choice when a battered woman is accused either of murdering her abuser or cooperating with her batterer's criminal activity.

It appears as though we have chosen to buy into the myth of the battered woman syndrome theory to assist the claims of domestic violence victims who use necessary force to defend themselves. Despite the acceptance of the battered woman syndrome theory in the self-defense context, it does not appear as though the theory is actually believed. The empirical support for the theory does not withstand scrutiny. The theory has not been extended to the logical next step in the duress context. And, ultimately, any theory that depicts battered women as incapable of self-help or rational decision making proves too much. That most battered women ultimately leave their abusers demonstrates that battered women are capable of saving themselves and surviving outside of abusive relationships. 
Perhaps to assist defendants whose use of force was not actually justified, advocates of the battered woman syndrome have transformed claims of self-defense into claims of mental defect at the expense of the right of other women to argue that their conduct was justified. As an alternative, defendants should be permitted to explain to juries the circumstances surrounding the abusive relationship and then be expected to make a prima facie showing that the use of force was necessary. Juries should understand the objective circumstances surrounding the individual woman's choices, giving context to a woman's claim that her use of force was necessary. If a woman's perception that her use of force was necessary is reasonable, based on her abuser's past history of violence, the events leading up to moment she killed him, and the lack of any safe alternatives, then she may have a valid claim of self-defense, even in the absence of an imminent threat. In an effort to facilitate their claims, however, we should not continue to embrace the theory of battered woman syndrome, which has little scientific support, inaccurately portrays the victims of domestic violence as irrational and helpless, and does not "fit" with the elements of self-defense that is supposedly supports. 